The Place where Huni probably Buried

\title{
Bohai,Xu
}

Address: Suzhou Industrial Park, Suzhou, China

Abstract: From the paper, we can speculate that Huni is exactly 吴回 (wuhui). Besides, the pronunciation of Huni resembles 吴回(wuhui). From the paper I speculate that the eagle in the statue unearthed in Taibo's tomb and the eagle in a statue of a man, dating from the State of Yue era, the eagles in the two statues resemble the God Horus in Egypt, so I can also get a conclusion that Wuxi (无锡) and Zhejiang (浙江) was once Egypt's colony. I can also get a conclusion that Zhangshan Hill (嶂 山) means Egypt governor or pharaoh had come to Wuxi.

Besides, we can get a conclusion that Chanshan Hill (产山) is a man-made pyramid, and Heliekou (河埒口) means enclosure around the man-made pyramid- Chanshan Hill, this pyramid complex looks like Djoser's Pyramid Complex which has enclosure around it. From the paper, we can conclude that Huishan clay figurines (惠山泥人) are ushabtis with Chinese characteristic, it indicates that Wuxi (无锡) was the colony of ancient Egypt. So Wuxi（无锡） means binding spot, Mount Xi（锡山） means a binding hill. And the ruins of Mount Xi(锡山) resemble "Pyramid of Khufu" in Giza pyramid complex. So we can get a hypothesis that Mount Xi(锡山) is a man-made pyramid.

Furthermore, Wuxi （无锡）is the cradle of Chinese Wu culture（吴 
文化)， I think this is owing to Huni. So from the above, we can speculate that Huni probably buried in Mount Xi，Wuxi (无锡锡山). 
Huni (original reading unknown) was an ancient Egyptian king and the last pharaoh of the 3rd dynasty during the Old Kingdom period. Following the Turin king list, he is commonly credited with a reign of 24 years, ending c. $2600 \mathrm{BC}$.

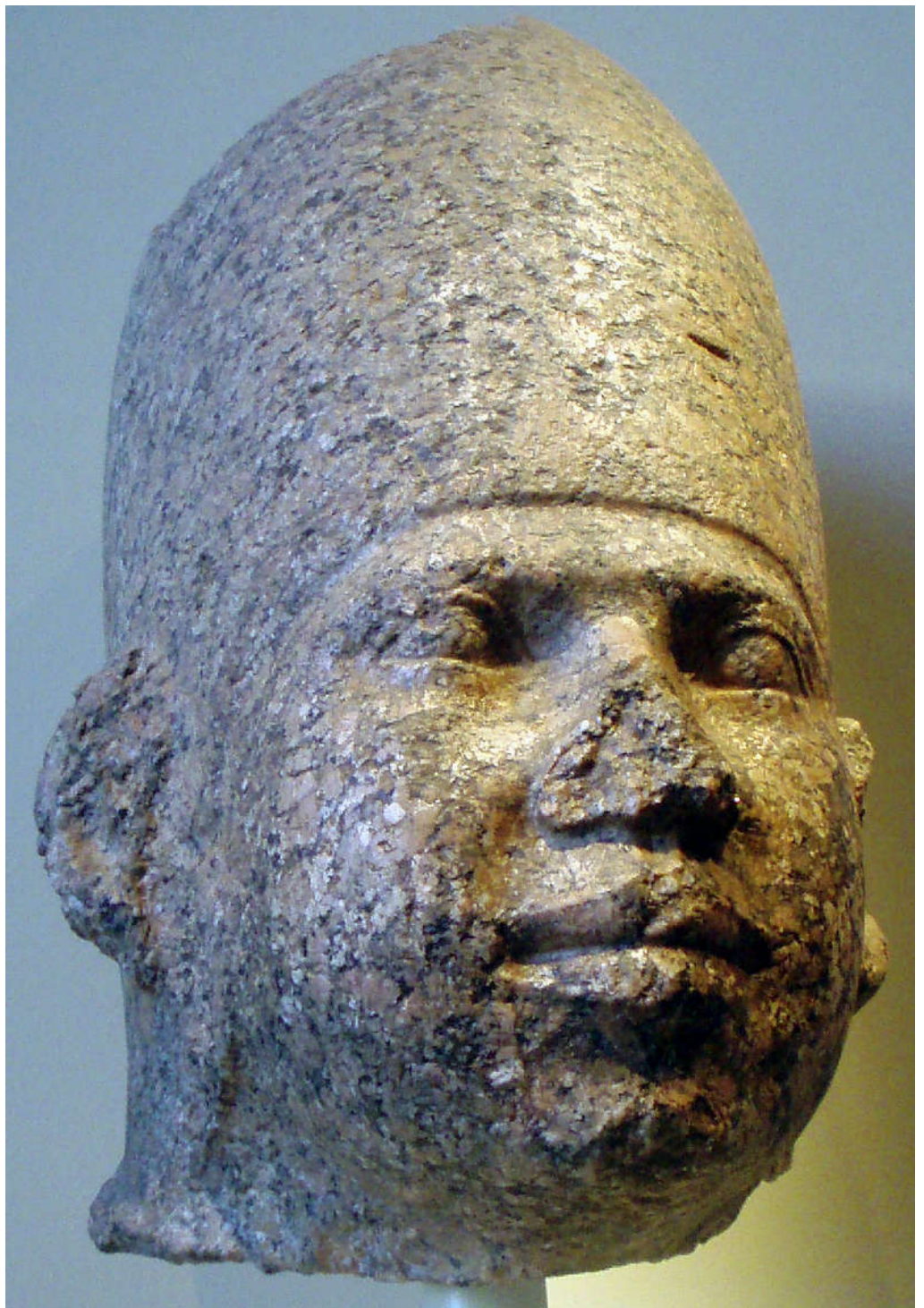

Pink granite head identified as Huni, Brooklyn Museum

Huni's chronological position as the last king of the third dynasty is seen as fairly certain, but there is still some uncertainty on the succession order of rulers at the end of the 3rd dynasty. It is also unclear under which Hellenized name the ancient historian Manetho could have 
listed him in his historical writing Aegyptiacae. Most possibly he is to be identified with the Hellenized name Aches, as Winfried Barta proposes. Many Egyptologists believe that Huni was the father and direct predecessor of king Sneferu, but this is questioned by other scholars. Huni is seen by scholars as a confusing figure in Egyptian history, because he was long remembered in Egyptian traditions, but only very few documents, objects or monuments have endured. (Toby A. H. Wilkinson: Early Dynastic Egypt. Routledge, London/ New York 1999, ISBN 0-415-18633-1, p. 85-89.)

Huni is not a well attested pharaoh; most of the attestations only point indirectly to him. There are only two contemporary objects with his name.

The first one is a conical stele made of red granite, discovered in 1909 on the island of Elephantine. The object is 62.99 inches $(160.0 \mathrm{~cm})$ long, 27.16 inches $(69.0 \mathrm{~cm})$ thick and 19.69 inches $(50.0 \mathrm{~cm})$ broad. Its shape resembles a typical Benben stele, as known from mastaba tombs of early dynastic kings. 


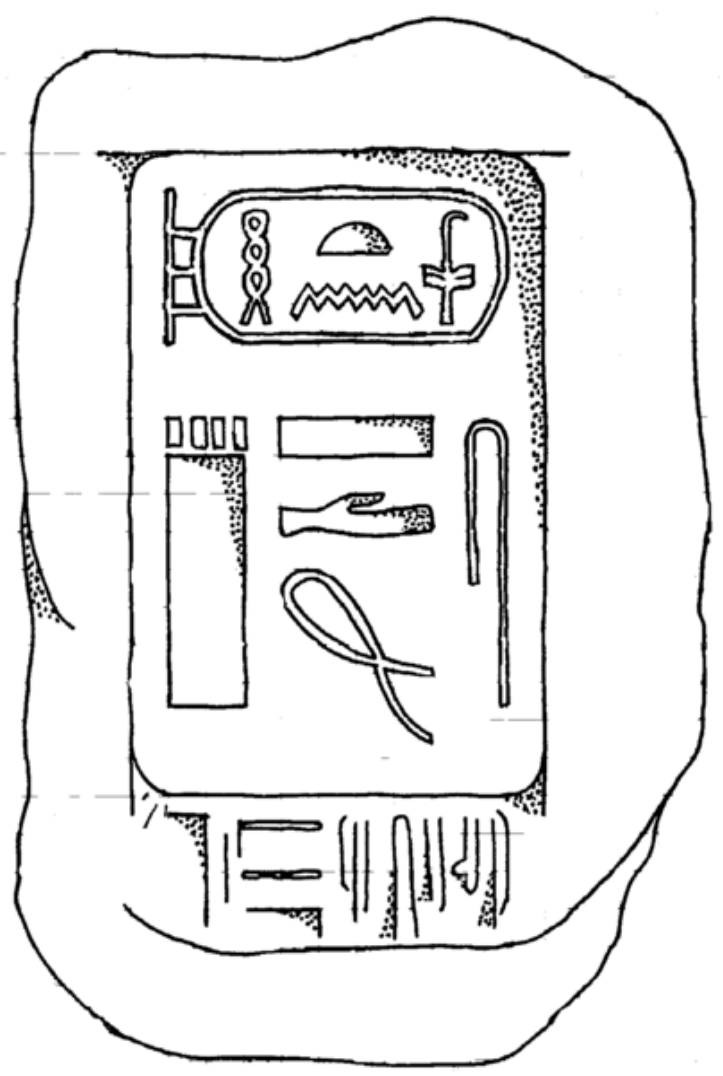

Granite cone uncovered on Elephantine and inscribed with Huni's cartouche

The second finding, discovered in 2007, is a polished stone bowl made of magnesite, found at South-Abusir in the mastaba tomb AS-54, belonging to a high official, whose name is yet unknown to archaeologists. The stone vessel inscription mentions Huni's name without a cartouche, but with the Njswt-Bity title. The orthography of the hieroglyphs that form Huni's name makes a reading as Njswt-Hw or Hw-en-Niswt plausible.

Finally, Huni is attested in the papyrus Prisse, in the Instructions of Kagemni, probably dating to the 13th dynasty. The papyrus gives an important indication about Huni's succession in column II, line 7:

"But then the majesty of king Huni died and the majesty of king Snefru was now raised up as beneficient king in this entire land. And Kagemni was raised as the new mayor of the royal capitol and became vizir of the king." 
Most scholars today think that this extract may strengthen the theory that Huni was the last king of the 3rd dynasty and immediate predecessor of king Snefru (the first ruler of the 4th dynasty). The Abydos kinglist, which also dates to the 19th dynasty, mysteriously omits Huni's name and gives instead a Neferkara I who is unknown to Egyptologists. And in my point of view, this extract indicated that Huni was overthrown by king Snefru (the first ruler of the 4th dynasty).

The genealogical position of Huni in the family line of ruling kings, during the time when the 3rd dynasty ended and the 4th started, is highly disputed. Contemporary and later documents often mention Huni and his follower Snefru in the same sentence, always in direct succession. Therefore, Egyptologists and historians believe that Huni might have even been related to Snefru. A key figure in this case is queen Meresankh I, the royal mother of Snefru. She definitely bore the title of a queen, but no contemporary source connects her name with the title of a daughter or wife of Huni. This circumstance raises doubts in the family relationship between Huni and Snefru. Today most scholars prefer to believe the historian Manetho, who claims in his Aegyptiacae that with the inthronisation of Snefru a different royal house gained power over Egypt and a new dynasty had begun.( Silke Roth: Die Königsmütter des Alten Ägypten von der Frühzeit bis zum Ende der 12. Dynastie. Harrassowitz, Wiesbaden 2001, ISBN 3-447-04368-7, page 68-69 \& 385). So I think this can also proved Huni was overthrown by Snefru. 
It seems though, that Huni undertook some building projects. The Turin Canon, which is rather modest about additional informations concerning the listed kings, credits Huni with the erection of a certain building, for which Huni must have been honoured in later times.

After his death, Huni seemed to have enjoyed a long lasting mortuary cult. The Palermo stone, which was made over a hundred years after Huni's death, mentions donations made to a funerary complex temple of Huni. Huni's name is also mentioned in the Prisse Papyrus, a further evidence that Huni was remembered long after his death since the papyrus was written during the 12th dynasty.

In the early 20th century, the Meidum pyramid was often credited to Huni. One long-held theory posited that Huni had started a stepped pyramid, similar to that of king Djoser, Sekhemkhet and Khaba, but architecturally more advanced and with more and smaller steps. 


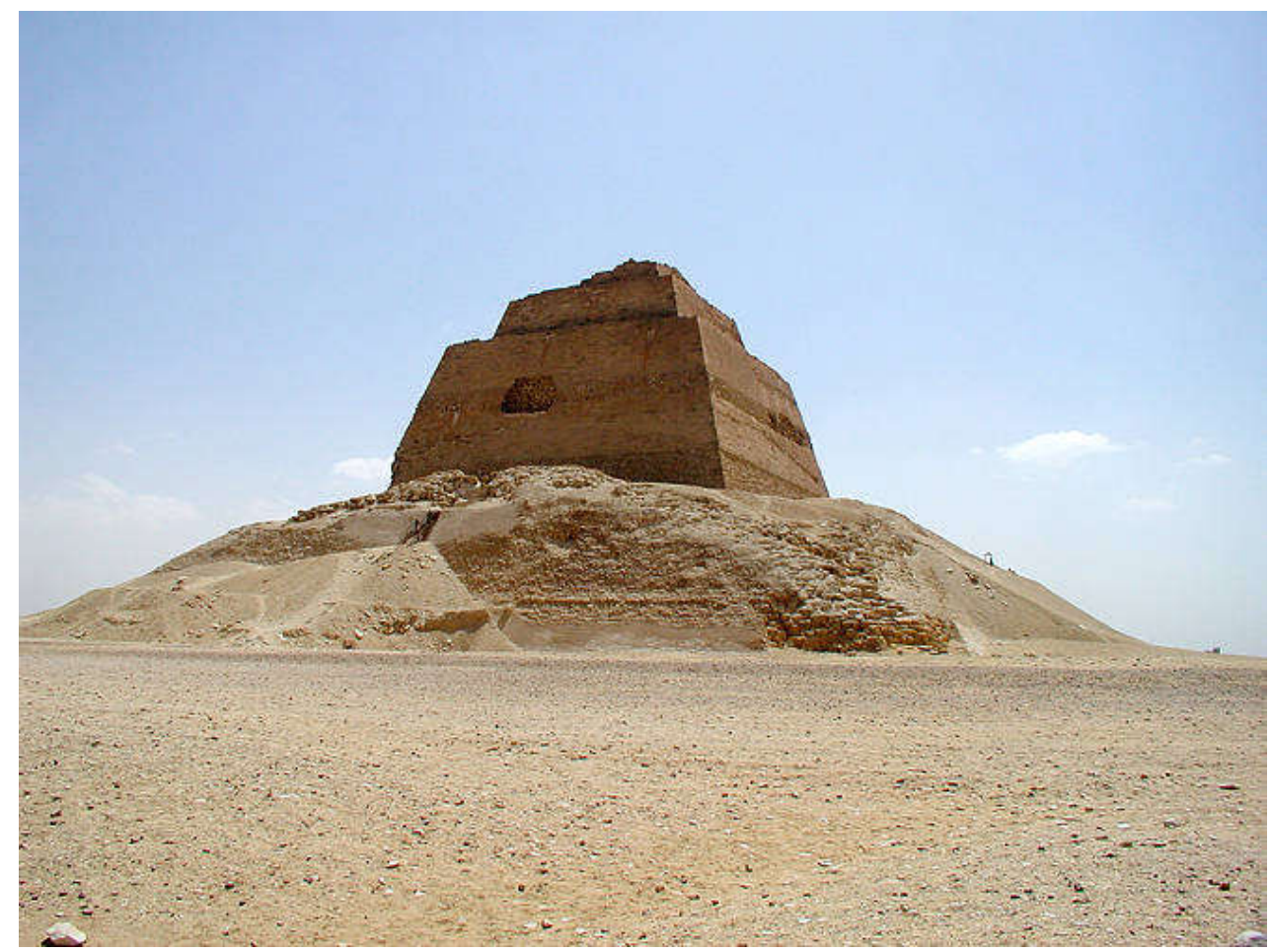

The Meidum pyramid, initially believed to have been started by Huni, is now thought to be exclusively the work of Snefru.

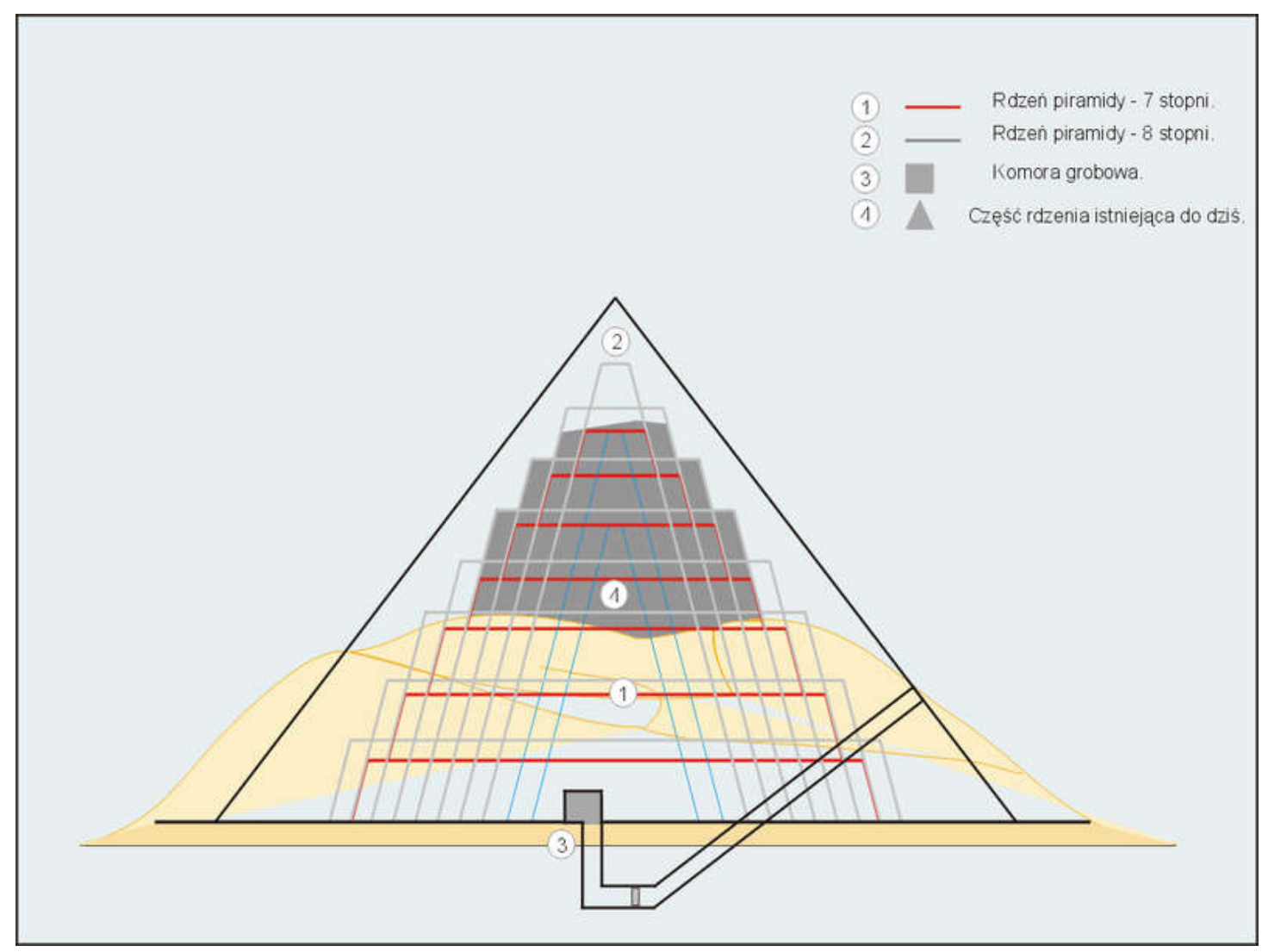

The structure of the Meidum pyramid

Closer examinations of the pyramid surroundings however revealed 
several tomb inscriptions and pilgrim graffitos praising the "beauty of the white pyramid of king Snefru". They further call for prayers to Snefru and "his great wife Meresankh I". Additionally, the surrounding mastaba tombs date to the reign of King Snefru. Huni's name has yet to be found anywhere near the pyramid. These indices led Egyptologists to the conclusion that the pyramid of Meidum was never Huni's, but rather an achievement of Snefru, planned and constructed as a cenotaph.

Several small step pyramids along the Nile river are also credited to Huni. Those small pyramids had a cultic function and marked important royal estates. They contained no internal chambers and were not used for burial purposes. One of them is located at the eastern end of Elephantine island and a granite cone with Huni's name was discovered nearby in 1909. Therefore, this little pyramid is the only one that may be credited to Huni with some certainty.( Günter Dreyer, Werner Kaiser: Zu den kleinen Stufenpyramiden Ober- und Mittelägyptens. In: Mitteilungen des Deutschen Archäologischen Instituts, Abteilung Kairo (MDAIK), vol. 36, 1980, p. 57).

And the name of Huni has the following forms: 


\section{Prenomen (Praenomen)}

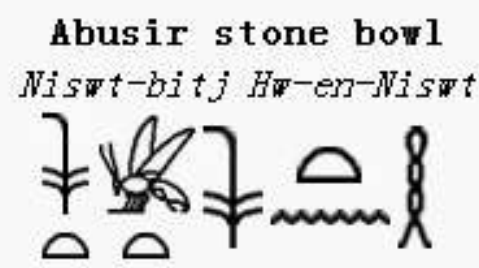

Elephantine cone/Palermo stone

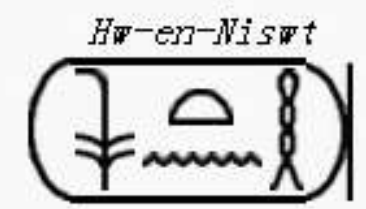

Papyrus Prisse

$H w j$

The smiter

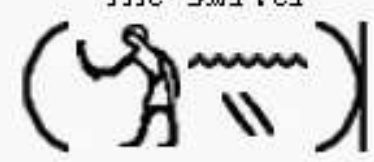

Saqqara Tablet

$H_{w} j$

The smiter

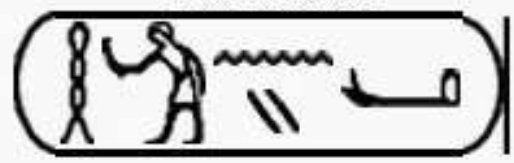

Turin King List

King HW...

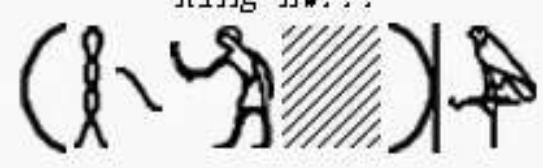

And the Prenomen of Huni has four symbols: $a \neq, a \geq, a$ 8

First look at this wick symbol $\mathcal{R}$. Westerners use alphabetic spelling to think that this wick symbol is the letter $h$. There is also a symbol $\square$ for 
the pronunciation of $h$, which is called the reed shelter. These two symbols are equivalent.

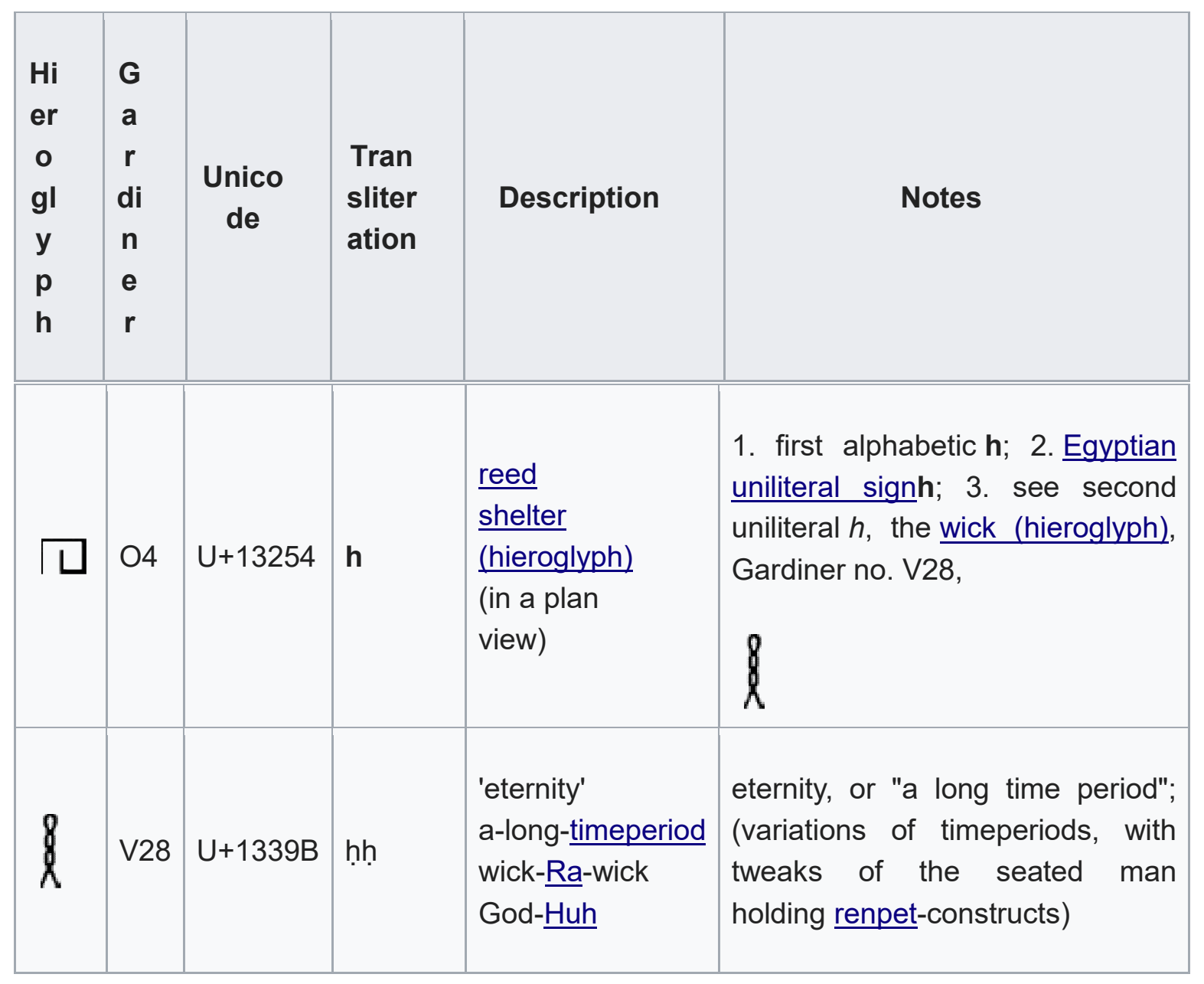

And the symbol $\lceil\mathrm{L} \mid$ resembles the Chinese character 回. 


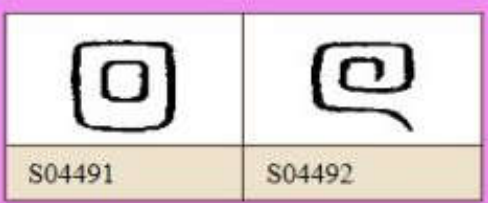

LST Seal (六墨通莗的篦體字) Characters

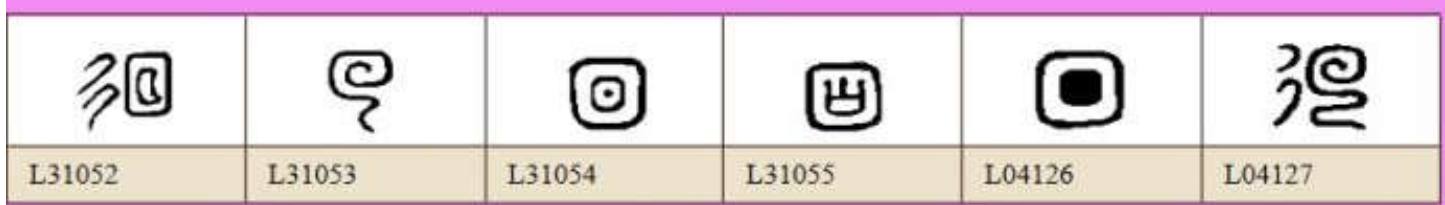

Bronze (金文编裏的字) Characters

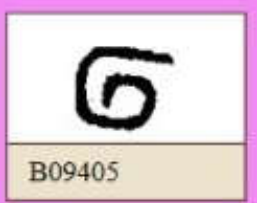

The symbol of $\mathcal{R}(\sqrt{\square})$ resembles Chinese character 回 in glyph and pronunciation(h). And the meaning? In ancient Egyptian symbols, the wick-Ra-wick symbol 8 ○ 8 means eternity. In fact, any symbol placed between two wick symbols means cyclical. So the symbol indeed has the meaning of Chinese character 回. The symbol $\mathcal{R}$ is completely consistent with the Chinese character 回 in glyph ,pronunciation(h) and meaning. So it is indeed 回 !

Now let us look at the Chinese character 吴: 


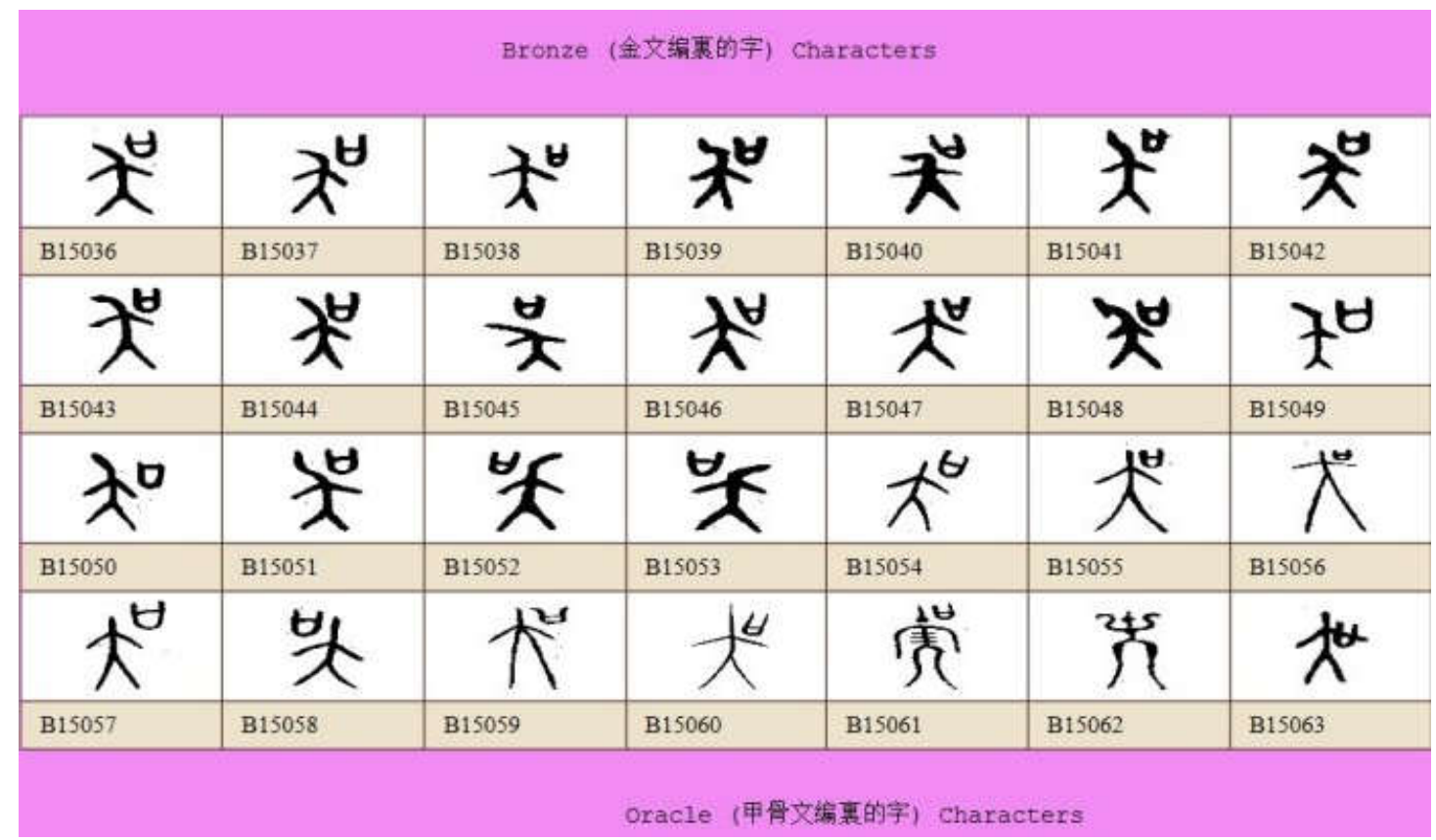

Actually the two symbols $¥$ and $\cong$, the prenomen of Huni exactly constitute glyph of 吴 in bronze character. But why did the symbol the prenomen of Huni disappear?

Now let us see what 吴 means. Its original meaning means that a person screams while running, and turning back, implying the call of the original hunter. So 吴 also has the meaning of 回, accurately from the combination of the prenomen of Huni.

While in ancient Egyptian symbols, the symbol $\neq$ means rush. It writes su, maybe the original pronunciation is to read “速”! And its pronunciation is similar to “吴”. Therefore, this symbol means that the original meaning of“吴”has the meaning of "running".

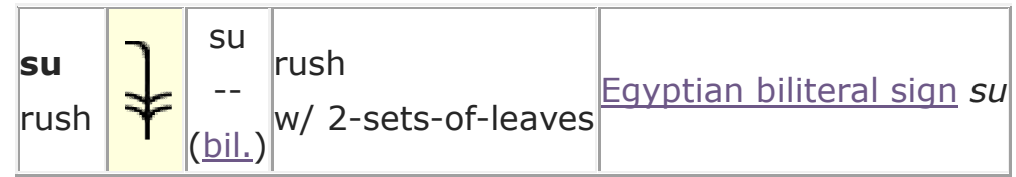

At last, what is the meaning of 
Mountains and Rivers, Tianwu is the water god in the ancient Han myths and legends. So you can see that the symbol of 吴" is gone, but still retains the legend of the water god Tianwu.

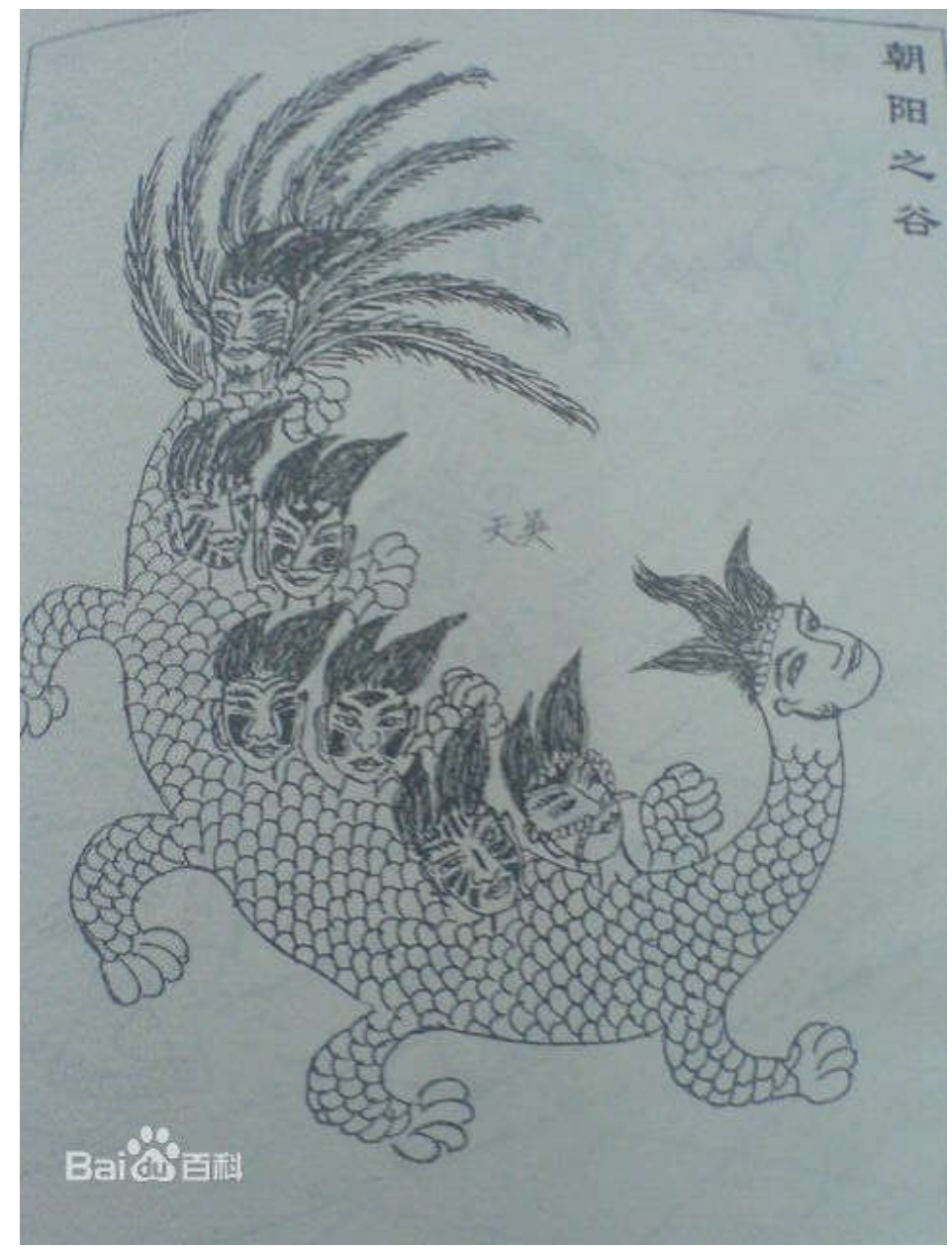

The water god Tianwu (天吴)

Besides, Heh (also Huh, Hah, Hauh, Huah, and Hehu) was the personification of infinity or eternity in the Ogdoad in Egyptian mythology. His name originally meant "flood", referring to the watery chaos that the Egyptians believed existed before the creation of the world. (Allen, James P. Genesis in Egypt: The Philosophy of Ancient Egyptian Creation Accounts. Yale Egyptological Seminar, 1988 ) The Egyptians envisioned this chaos as infinite, in contrast with the finite created world, so Heh 
personified this aspect of the primordial waters. Heh's female counterpart was known as Hauhet, which is simply the feminine form of his name. ( Wilkinson, Richard H. (2003). The Complete Gods and Goddesses of Ancient Egypt. Thames \& Hudson. p. 109)

Like the other concepts in the Ogdoad, his male form was often depicted as a frog, or a frog-headed human, and his female form as a snake or snake-headed human. The frog head symbolised fertility, creation, and regeneration, and was also possessed by the other Ogdoad males Kek, Amun, and Nun. (Rush, John (2007). The Twelve Gates: A Spiritual Passage Through the Egyptian Books of the Dead. Berkeley, CA: Frog. p. 281.) The other common representation depicts him crouching, holding a palm stem in each hand (or just one), (Owusu, Heike (2008). Egyptian Symbols. New York, NY: Sterling. p.73. ) sometimes with a palm stem in his hair, as palm stems represented long life to the Egyptians, the years being represented by notches on it. Depictions of this form also had a shen ring at the base of each palm stem, which represented infinity. Depictions of Heh were also used in hieroglyphs to represent one million, which was essentially considered equivalent to infinity in Ancient Egyptian mathematics. Thus this deity is also known as the "god of millions of years". 


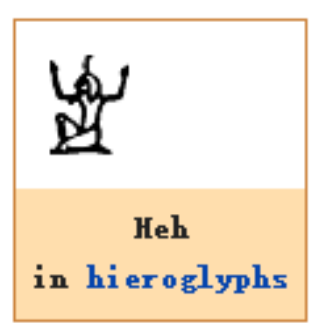

The god Heh was usually depicted anthropomorphically, as in the hieroglyphic character, as a male figure with divine beard and lappet wig. Normally kneeling (one knee raised), sometimes in a basket-the sign for "all", the god typically holds in each hand a notched palm branch (palm rib). Occasionally, an additional palm branch is worn on the god's head.

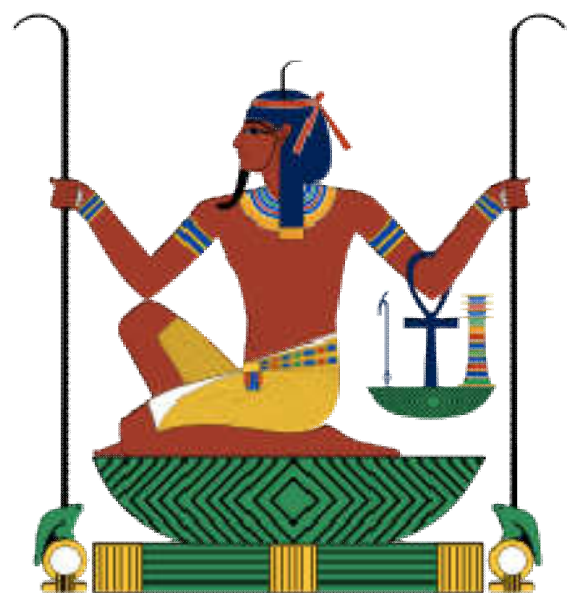

An aspect of Heh, holding a pair of notched palm branches

So from the above, we can see that the water god Tianwu(天 吴) resembles the Egyptian god Ḥeh in pronunciation and meaning.

Now in sum, we can speculate that Huni is exactly 吴回(wuhui). Besides, the pronunciation of Huni resembles 吴回(wuhui).

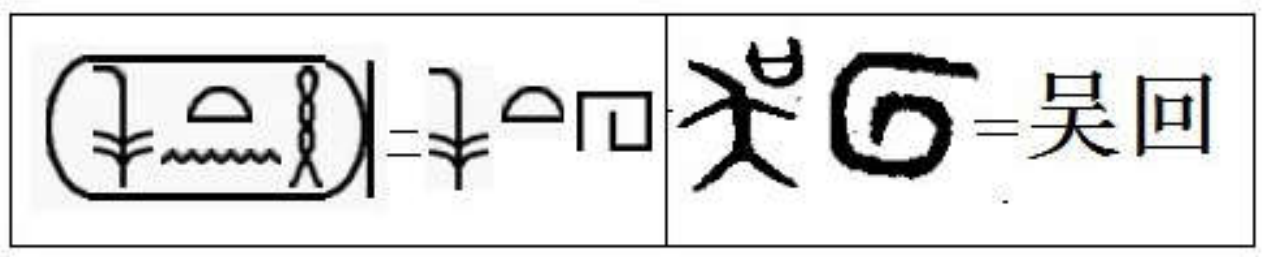

From the above, we can see that Huni is exactly 吴回(wuhui). But 
where is he buried? Let us see the paper below.

The Egyptian pyramids are ancient pyramid-shaped masonry structures located in Egypt. As of November 2008, sources cite either 118 or 138 as the number of identified Egyptian pyramids. Most were built as tombs for the country's pharaohs and their consorts during the Old and Middle Kingdom periods.

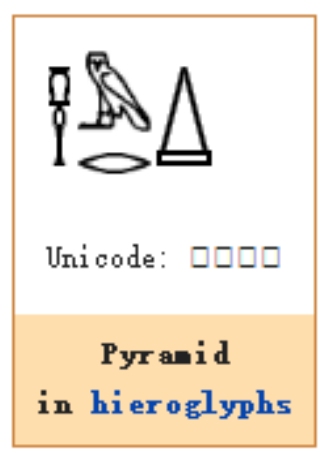

The earliest known Egyptian pyramids are found at Saqqara, northwest of Memphis. The earliest among these is the Pyramid of Djoser, which was built c. 2630-2610 BC during the Third Dynasty. (Gardner, Helen (1980) [1926]. De La Croix, Horst; Tansey, Richard G., eds. Art through the Ages (7th ed.). New York: Harcourt Brave Jovanovitch. p. 68. ISBN 0-15-503758-7.) This pyramid and its surrounding complex were designed by the architect Imhotep, and are generally considered to be the world's oldest monumental structures constructed of dressed masonry. (Lehner, Mark (1997). The Complete Pyramids. New York: Thames and Hudson. p. 84. ISBN 978-0-500-05084-2.)

The most famous Egyptian pyramids are those found at Giza, on the outskirts of Cairo. Several of the Giza pyramids are counted among the largest structures ever built. The Pyramid of Khufu at Giza is the largest 
Egyptian pyramid. It is the only one of the Seven Wonders of the Ancient World still in existence.

By the time of the Early Dynastic Period, those with sufficient means were buried in bench-like structures known as mastabas.

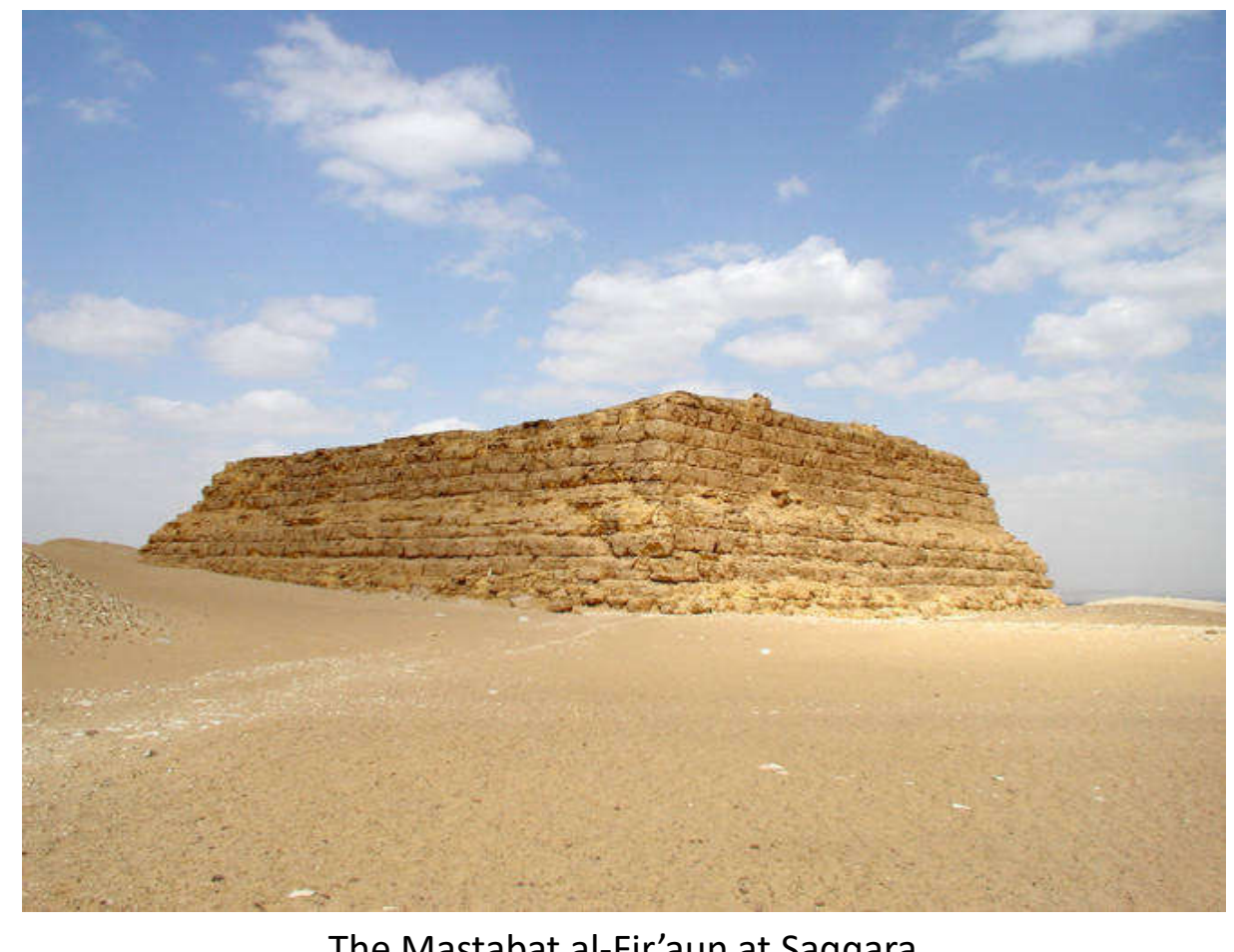

The second historically-documented Egyptian pyramid is attributed to the architect Imhotep, who planned what Egyptologists believe to be a tomb for the pharaoh Djoser. Imhotep is credited with being the first to conceive the notion of stacking mastabas on top of each other, creating an edifice composed of a number of "steps" that decreased in size towards its apex. The result was the Pyramid of Djoser, which was designed to serve as a gigantic stairway by which the soul of the deceased pharaoh could ascend to the heavens. Such was the importance of Imhotep's achievement that he was deified by later 
Egyptians. (Quirke, Stephen (2001). The Cult of Ra: Sun Worship in Ancient Egypt. Thames \& Hudson, pp. 118-120.)

The most prolific pyramid-building phase coincided with the greatest degree of absolutist rule. It was during this time that the most famous pyramids, the Giza pyramid complex, were built. Over time, as authority became less centralized, the ability and willingness to harness the resources required for construction on a massive scale decreased, and later pyramids were smaller, less well-built and often hastily constructed.

The shape of Egyptian pyramids is thought to represent the primordial mound from which the Egyptians believed the earth was created. The shape of a pyramid is thought to be representative of the descending rays of the sun, and most pyramids were faced with polished, highly reflective white limestone, in order to give them a brilliant appearance when viewed from a distance. Pyramids were often also named in ways that referred to solar luminescence. For example, the formal name of the Bent Pyramid at Dahshur was The Southern Shining Pyramid, and that of Senwosret at el-Lahun was Senwosret is Shining.

The Egyptians believed the dark area of the night sky around which the stars appear to revolve was the physical gateway into the heavens. One of the narrow shafts that extend from the main burial chamber through the entire body of the Great Pyramid points directly towards the center of this part of the sky. This suggests the pyramid may have been designed to serve as a means to magically launch the deceased 
pharaoh's soul directly into the abode of the gods.

All Egyptian pyramids were built on the west bank of the Nile, which, as the site of the setting sun, was associated with the realm of the dead in Egyptian mythology.( "Discovery Channel Nederland". Discoverychannel.co.uk. Archived from the original on 5 December 2004. Retrieved 16 November 2012.)

All of Egypt's pyramids, except the small Third Dynasty pyramid of Zawyet el-Amwat (or Zawyet el-Mayitin), are sited on the west bank of the Nile, and most are grouped together in a number of pyramid fields. Some of the most important of these are listed geographically, from north to south, below.

Giza is the location of the Pyramid of Khufu (also known as the "Great Pyramid" and the "Pyramid of Cheops"); the somewhat smaller Pyramid of Khafre (or Chephren); the relatively modest-sized Pyramid of Menkaure (or Mykerinus), along with a number of smaller satellite edifices known as "Queen's pyramids"; and the Great Sphinx of Giza.

Of the three, only Khafre's pyramid retains part of its original polished limestone casing, near its apex. This pyramid appears larger than the adjacent Khufu pyramid by virtue of its more elevated location, and the steeper angle of inclination of its construction - it is, in fact, smaller in both height and volume. 


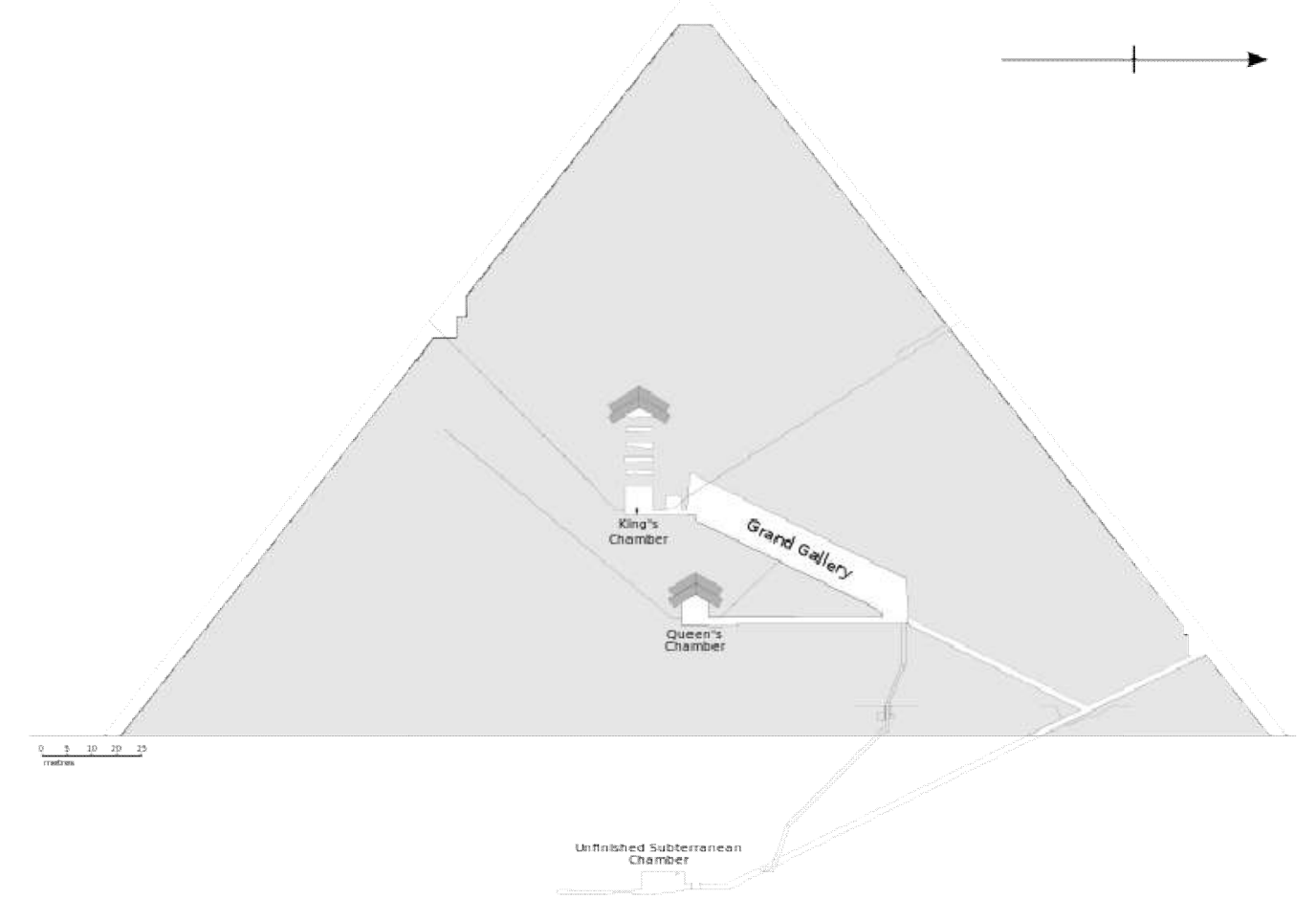

Diagram of the interior structures of the Great Pyramid. The inner line indicates the pyramid's present profile, the outer line indicates the original profile.

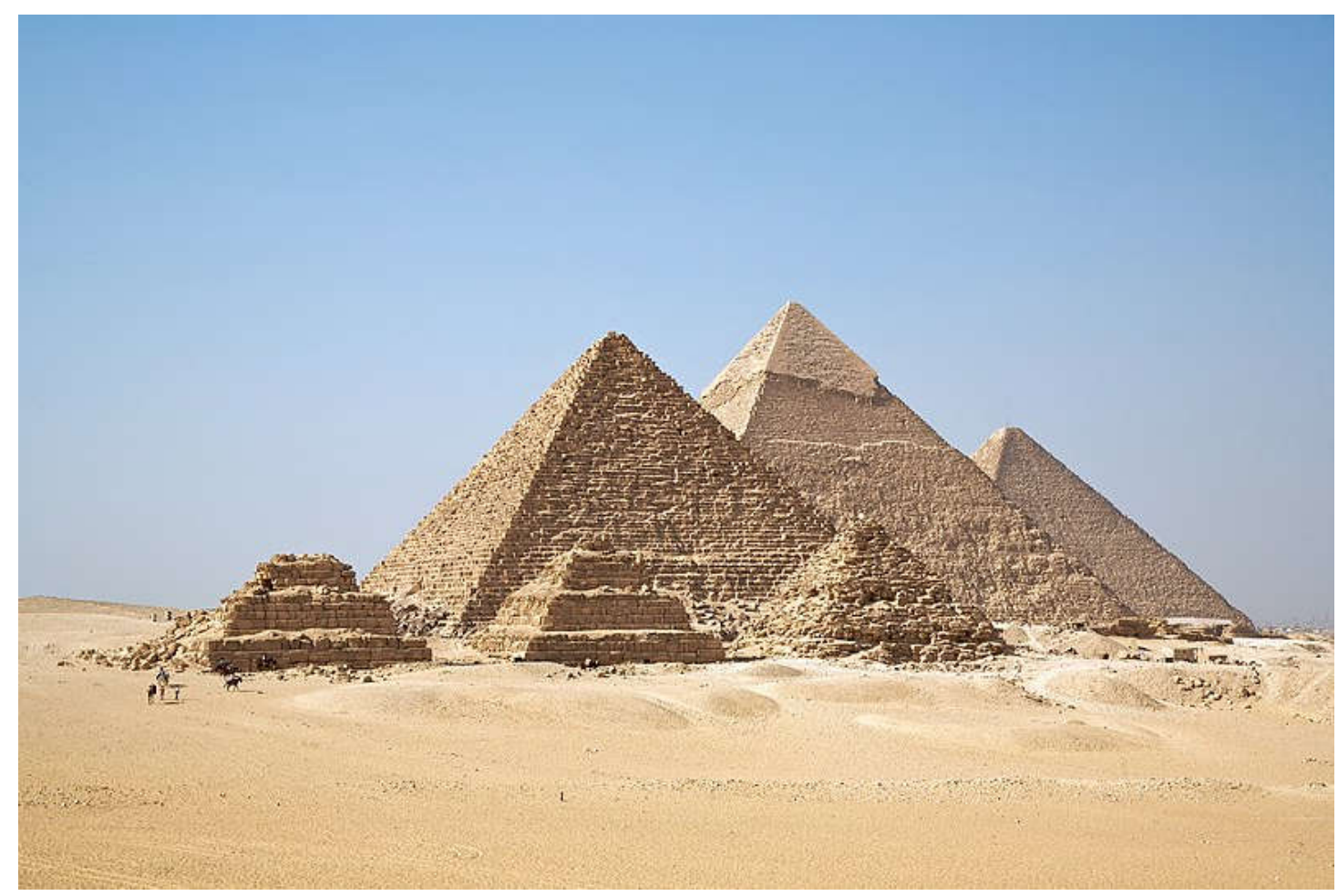

A view of the pyramids at Giza from the plateau to the south of the complex. From left to right, the three largest are: the Pyramid of Menkaure, the Pyramid of Khafre and the Great Pyramid of Khufu. The three smaller pyramids in the foreground are subsidiary structures associated with Menkaure's pyramid. 


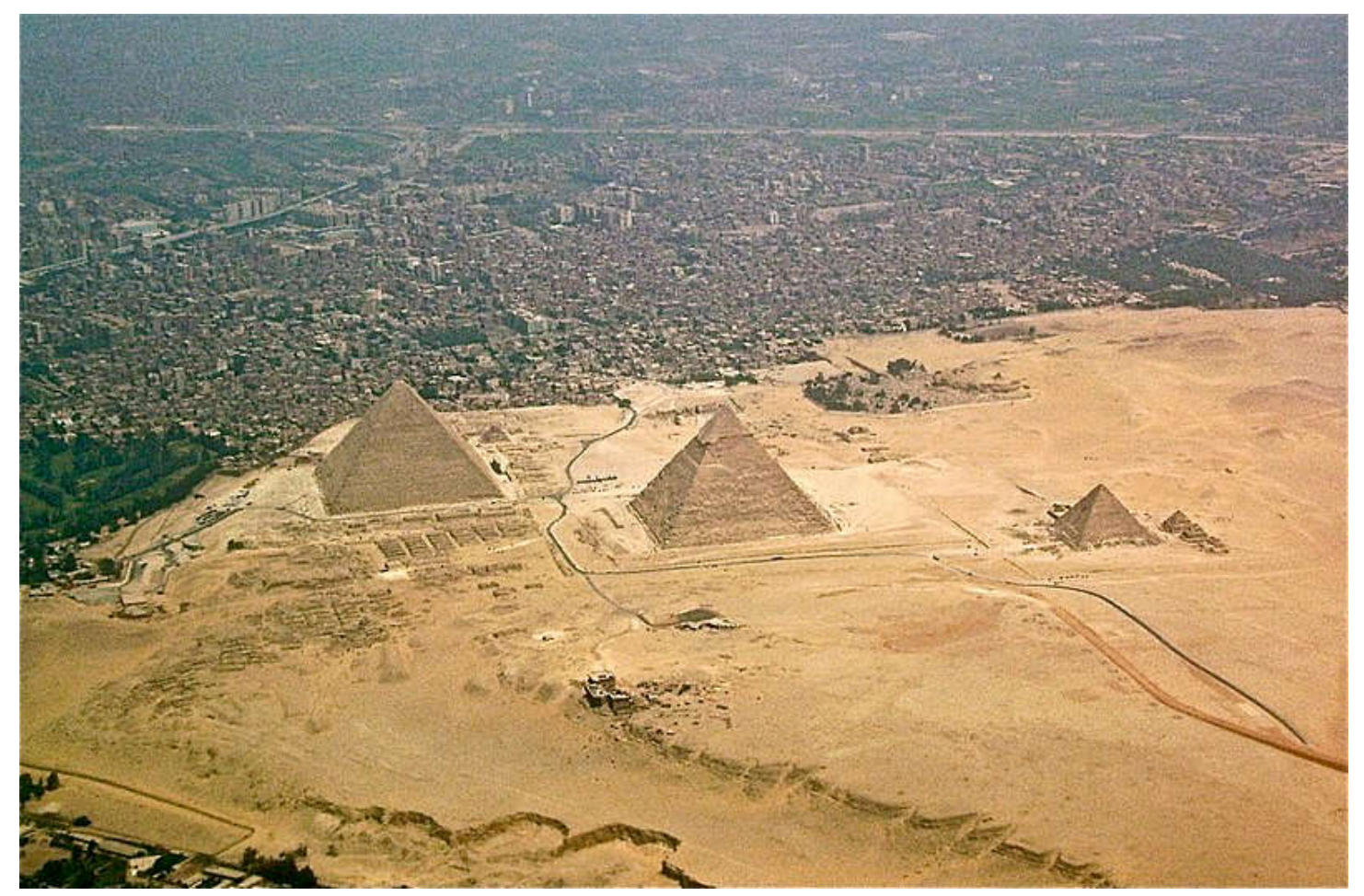

Aerial view of the Giza pyramid complex 


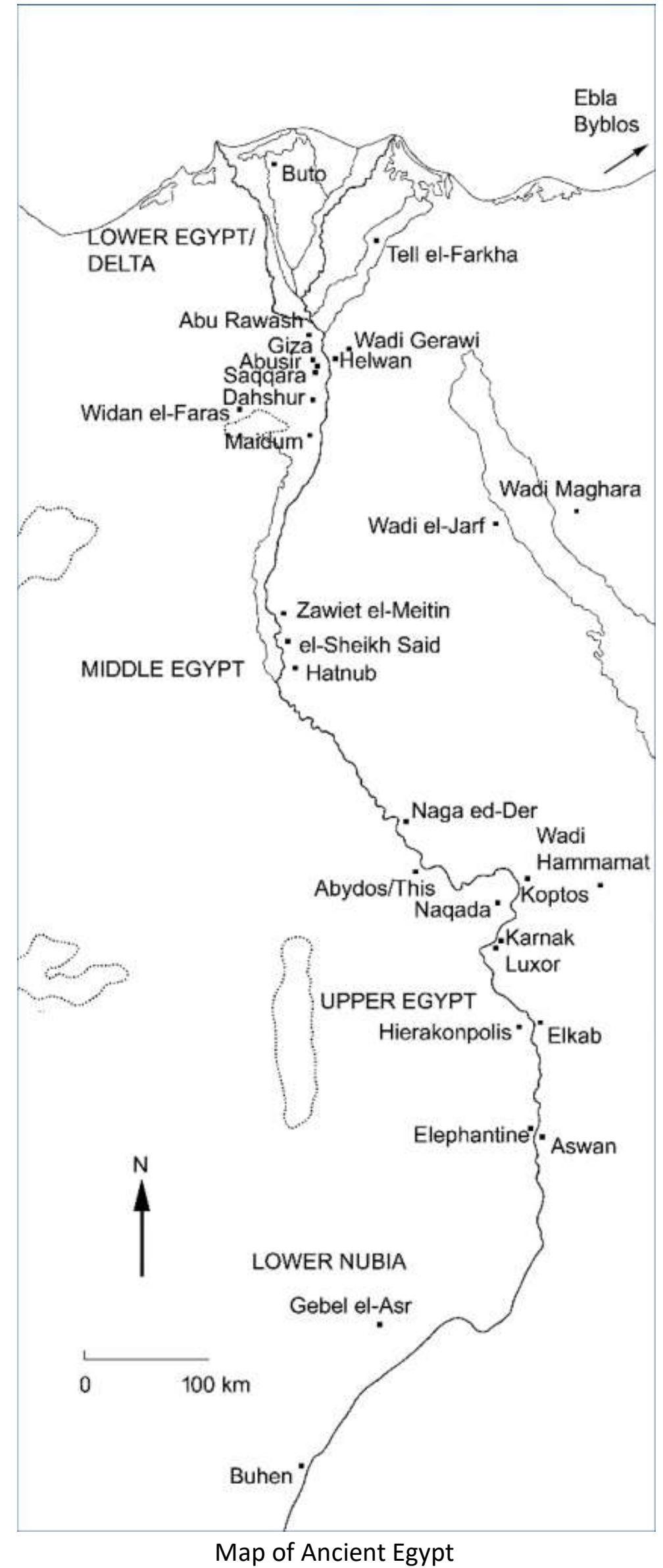




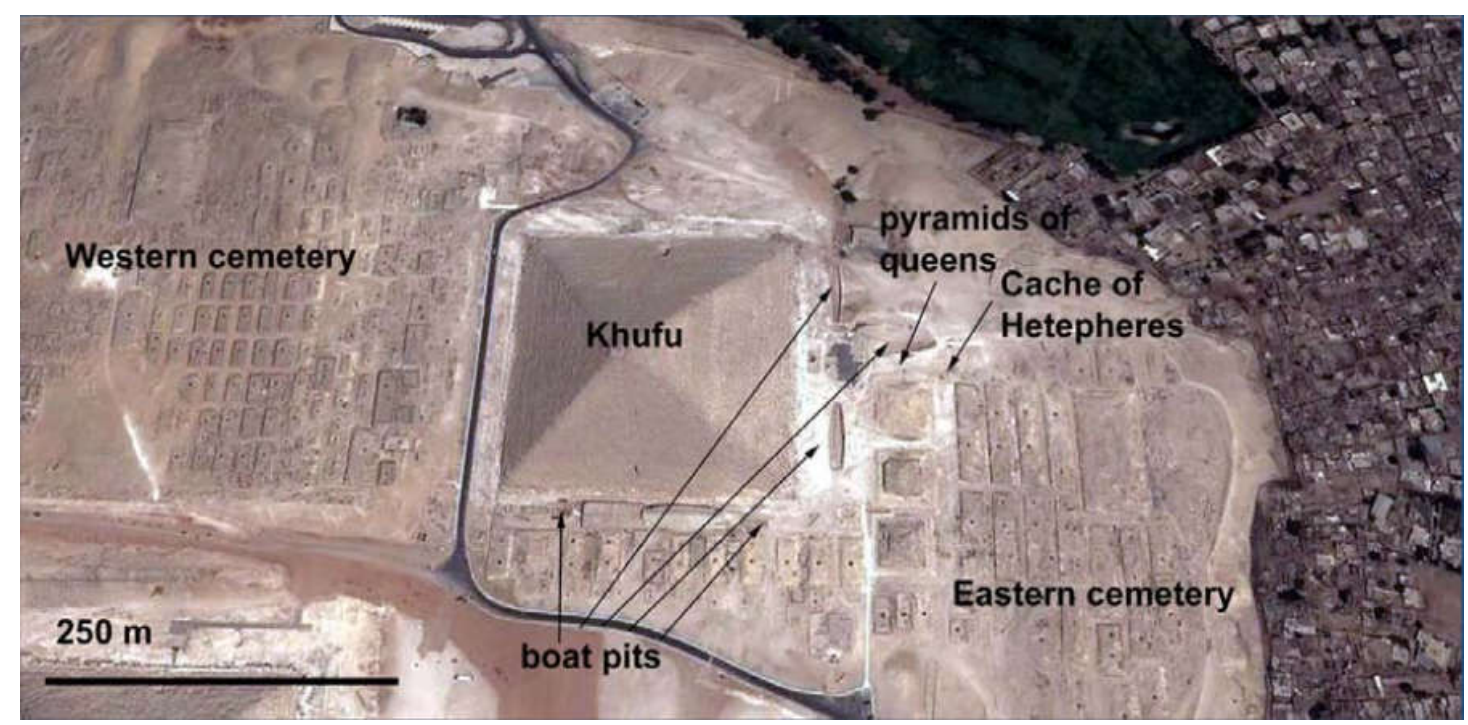

Map of Khufu cemetery

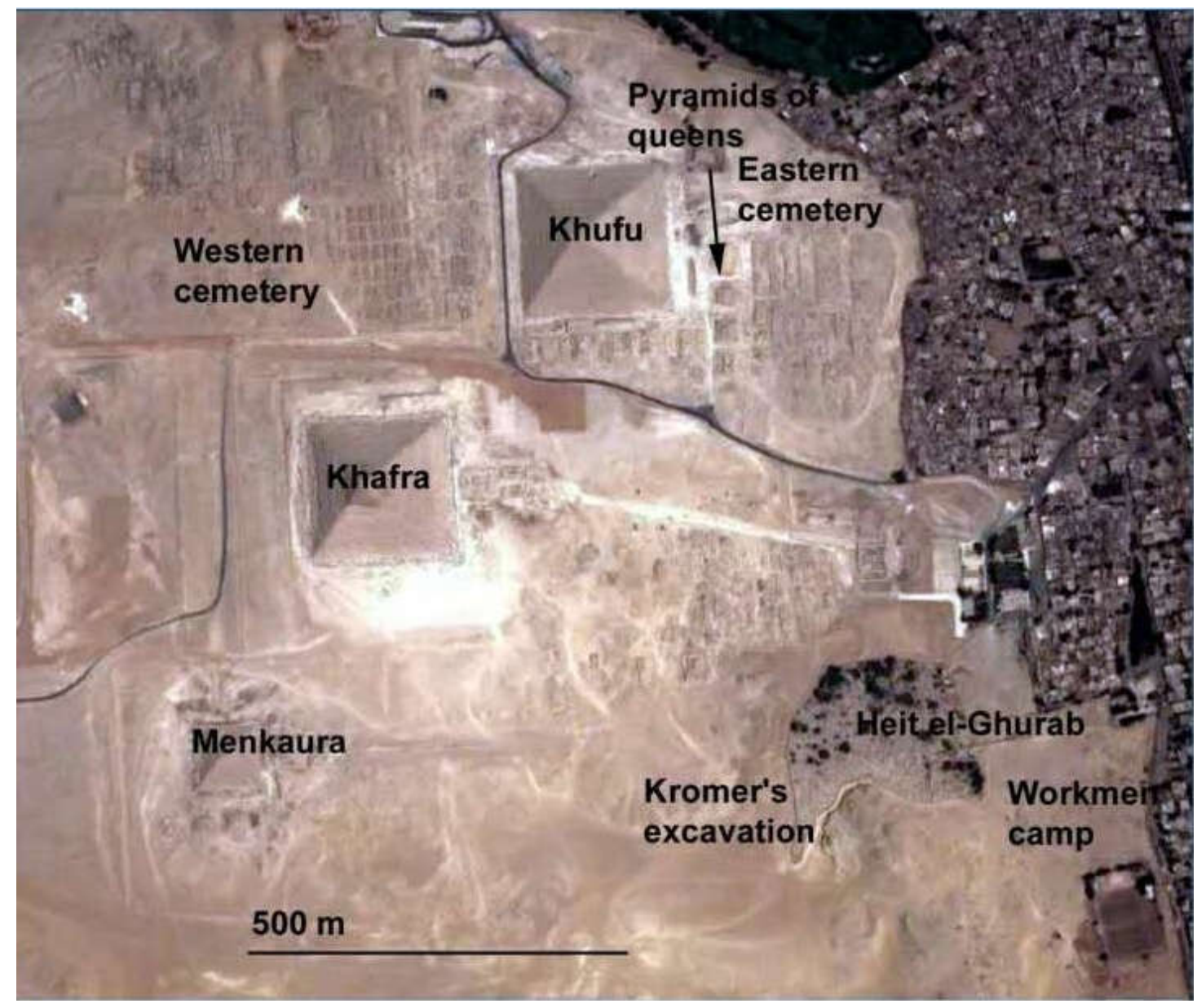

Satellite Map of Giza 


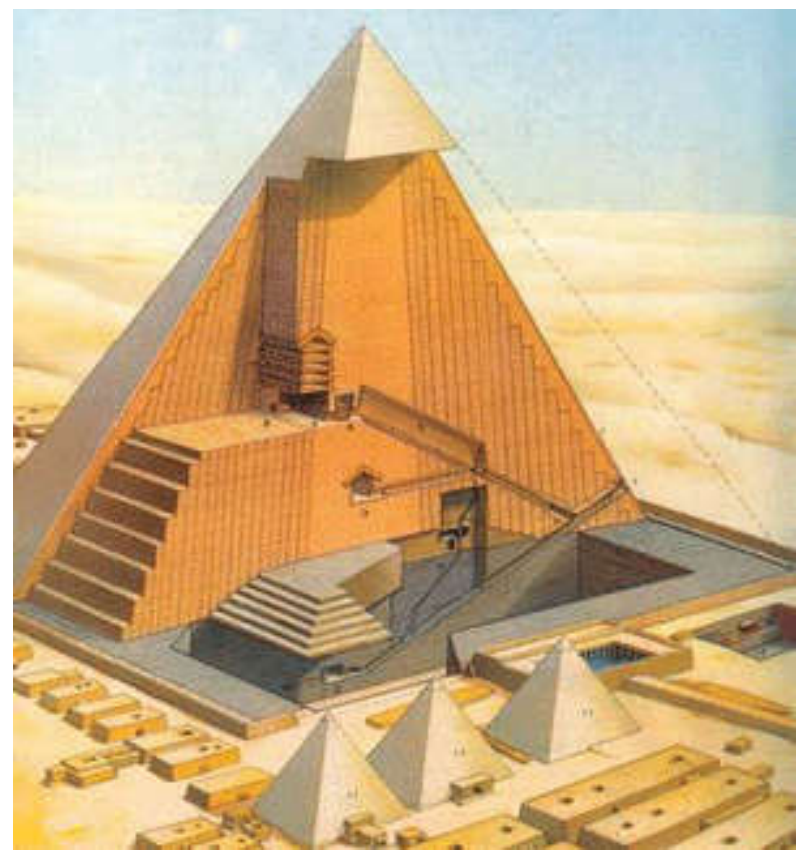

The Great Pyramid of Giza

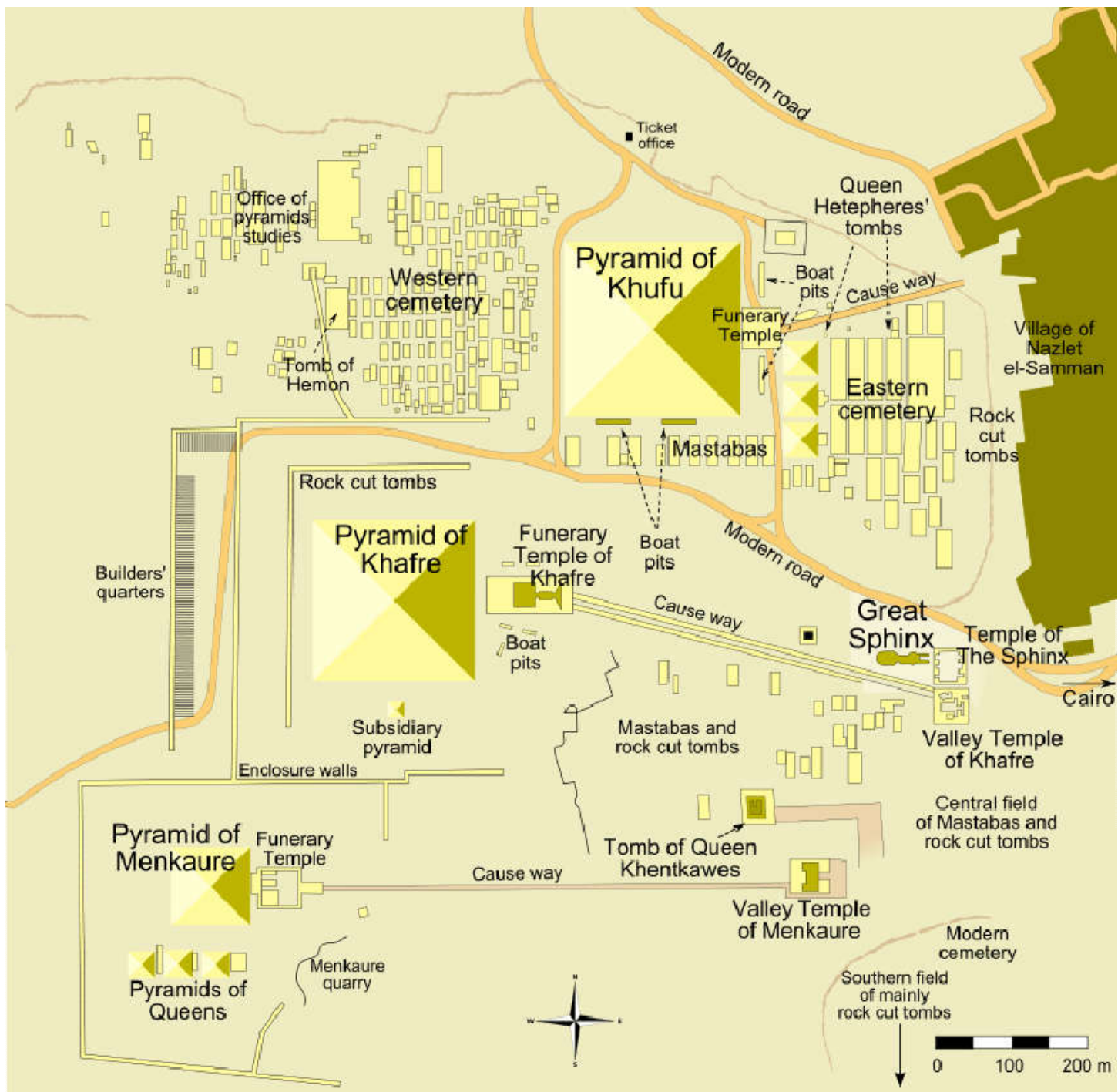




\section{Map of the Giza pyramid complex}

Zawyet el-Aryan, halfway between Giza and Abusir, is the location for two unfinished Old Kingdom pyramids. The northern structure's owner is believed to be pharaoh Nebka, while the southern structure, known as the Layer Pyramid, may be attributable to the Third Dynasty pharaoh Khaba, a close successor of Sekhemkhet. If this attribution is correct, Khaba's short reign could explain the seemingly unfinished state

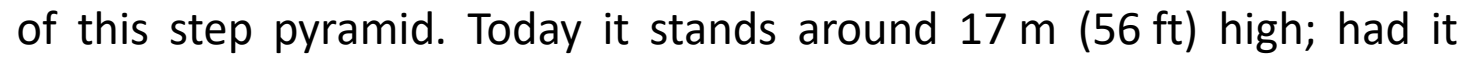
been completed, it is likely to have exceeded $40 \mathrm{~m}$ (130 ft).

The Layer Pyramid (known locally in Arabic as el haram el midawwar, Arabic: الهرم المدور, meaning 'rubble-hill pyramid') is a ruined step pyramid dating to the 3rd Dynasty of Egypt (2686 BC to 2613 BC) and located in the necropolis of Zawyet El Aryan. Its ownership is uncertain and may be attributable to pharaoh Khaba. The pyramid architecture, however, is very similar to that of the Buried Pyramid of king Sekhemkhet and for this reason is firmly datable to the 3rd Dynasty. 


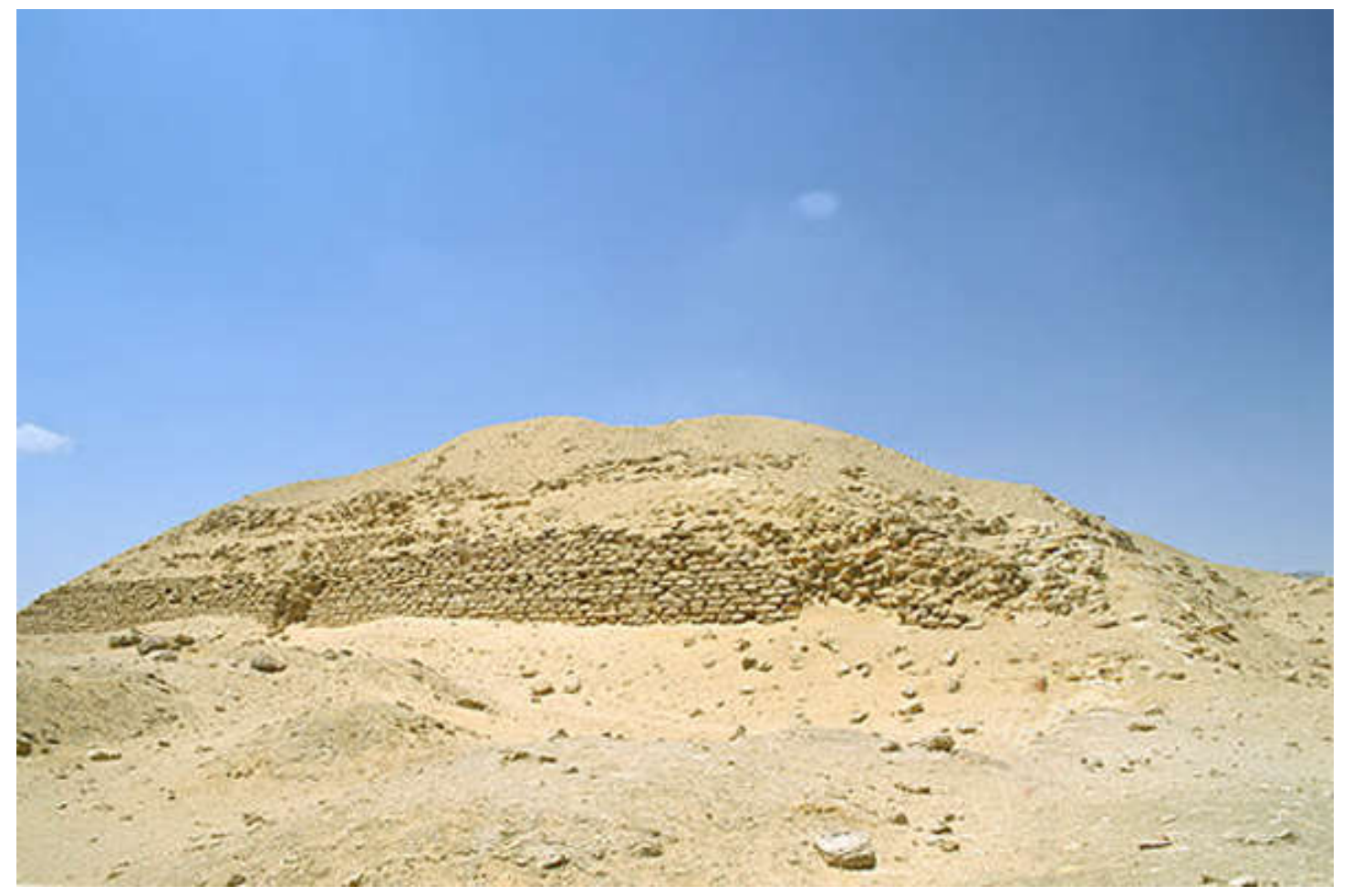

The ruins of the layer pyramid

The Layer Pyramid lies close to the necropolis of Zawyet El Aryan, $8 \mathrm{~km}$ (5.0 mi) south-west of Giza and $7 \mathrm{~km}(4.3 \mathrm{mi})$ north of Saqqara. The main structure is located on a rock ridge just above the floodplain.

The Layer Pyramid has a square base whose side is about $84 \mathrm{~m}(276 \mathrm{ft})$ long, slightly smaller than the step pyramids of Djoser and Sekhemket. Based on the dimensions of the pyramid of Djoser, the egyptologist Jean-Philippe Lauer estimated that the layer pyramid was originally planned to comprise five steps and would have reached c. 42-45 m (138-148ft) in height. (Jean-Philippe Lauer: Histoire monumentale des pyramides d'Égypte. Volume 1: Les pyramides à degrés (IIle Dynastie), Bibliothèque d'étude vol. 39. Institut français d'archéologie orientale Bibliothèque d'études, Paris 1962, p. 19-22.)Today, only two of these steps remain, reaching a height of about $17 \mathrm{~m}$ (56 ft). The current ruined state of the pyramid allows a view of its core, which is a $11 \mathrm{~m}^{2}$ (120 sq ft) 
pyramidal mound made of poor quality rough stone blocks taken from the local bedrock. This core is surrounded by a $2.6 \mathrm{~m}(8.5 \mathrm{ft})$ thick casing of the same masonry. This is in turn surrounded by 14 layers of mud bricks bonded with clay mortar and disposed almost vertically, with an inward inclination angle of $68^{\circ}$. Just as the inner-most stone casing of the pyramid core, each mud brick layer is $2.6 \mathrm{~m}$ ( $8.5 \mathrm{ft}$ ) thick.( Miroslav Verner: Die Pyramiden. Rowohlt, Wiesbaden 1999, ISBN 3-499-60890-1, p. 174-177.) 


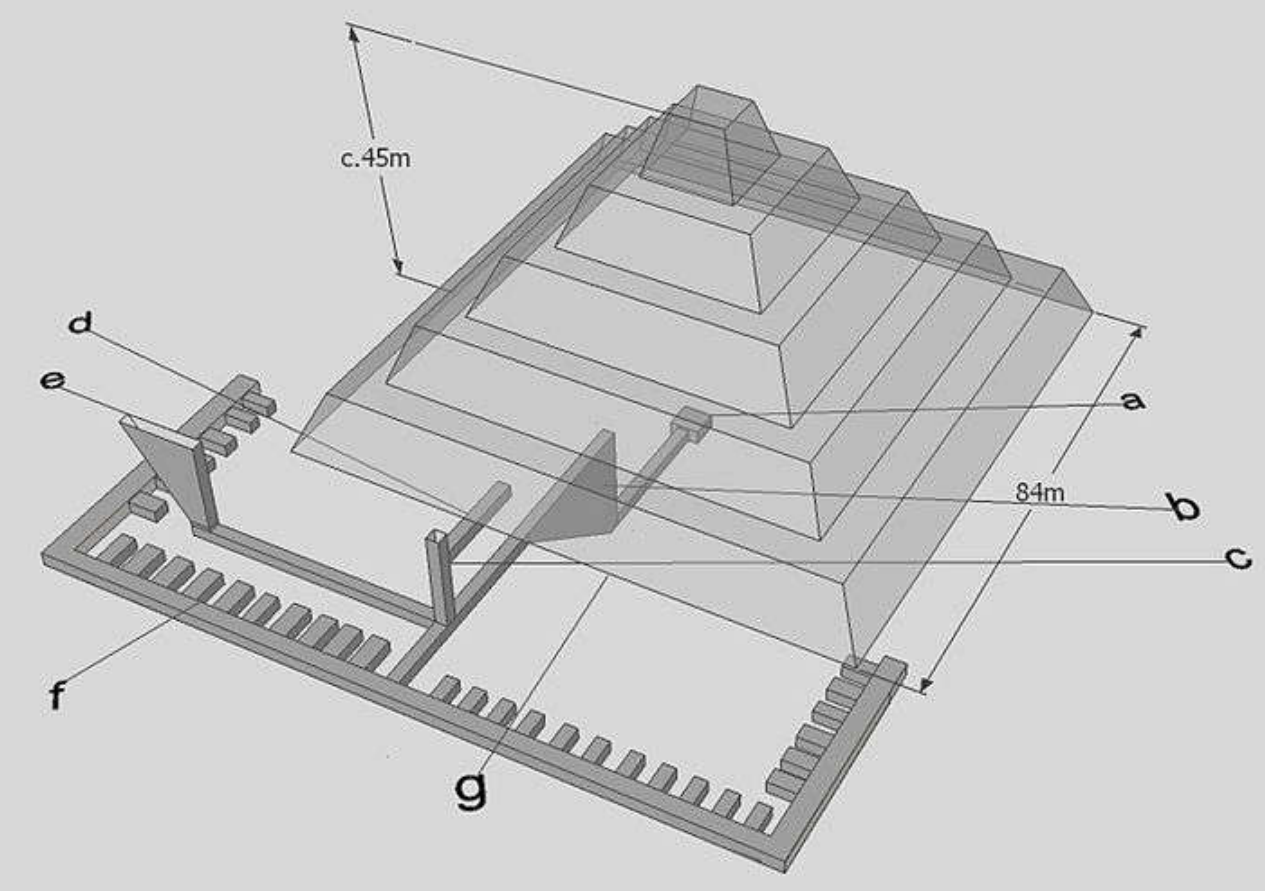

a. Burial Chamber beneath apex

b. Descent

c. Vertical access shaft outside the body of the pyramid

d. Abandoned horizontal passage

e. Staircase

f. U-shaped underground passage with 32 storage chambers

g. Step pyramid of five layers.

After Lehner and Verner

Plan of the Layer Pyramid.

The disposition of the substructures of the layer pyramid is extremely similar to that found in the Buried Pyramid of Sekhemket. Consequently, Mark Lehner and others suggest that the two pyramids must have been constructed very close in time.( Mark Lehner: The Complete Pyramids, London: Thames \& Hudson, 2008, ISBN 978-0-500-28547-3, p. 96.)

The entrance to the subterranean structures lies on the east, a 
disposition which would be unparalleled until the construction of the pyramid of Senusret II, almost 1000 years later.

The entrance immediately leads to a $36 \mathrm{~m}$ (118 ft) long steep stairway and then down on to a corridor which heads west. The corridor ends in a straight vertical shaft, at the top of which is the so-called upper corridor, an unfinished passage which goes south toward the center of the pyramid. At the bottom of the shaft is a T-shaped crossway. To the left, this crossway leads south to the lower corridor, half-way of which is a narrow stairway, so narrow that a sarcophagus could hardly have been passed through it. The lower corridor then finishes in the king's burial chamber. In this area of the stairway, Barsanti drew another gallery leading above the burial chamber, but this gallery is absent in Reisner's and Fisher's notes. To the right of the T-shaped crossway is a U-shaped gallery system. The ground plan of the gallery system resembles that of a comb, comprising rows of chambers, totalling 32 , which were possibly destined to be storage rooms for the gravegoods. (Miroslav Verner:Die Pyramiden. Rowohlt, Wiesbaden 1999, ISBN 3-499-60890-1, p. 174-177.) The gallery proved to be "clean and empty, as if the workmen had only left". (Mark Lehner: The Complete Pyramids, London: Thames \& Hudson, 2008, ISBN 978-0-500-28547-3, p. 96.)

The king's burial chamber is located $26 \mathrm{~m}$ ( $85 \mathrm{ft}$ ) below ground, is nearly square in shape, with a base of $3.63 \mathrm{~m} \times 2.65 \mathrm{~m}(11.9 \mathrm{ft} \times 8.7 \mathrm{ft})$, and a ceiling height of $3 \mathrm{~m}(9.8 \mathrm{ft})$. The burial chamber contained no 
traces of a sarcophagus, which together with the absence of artefacts in the gallery, hints to the premature death of the king. (Mark Lehner: The Complete Pyramids, London: Thames \& Hudson, 2008, ISBN 978-0-500-28547-3, p. 96.)

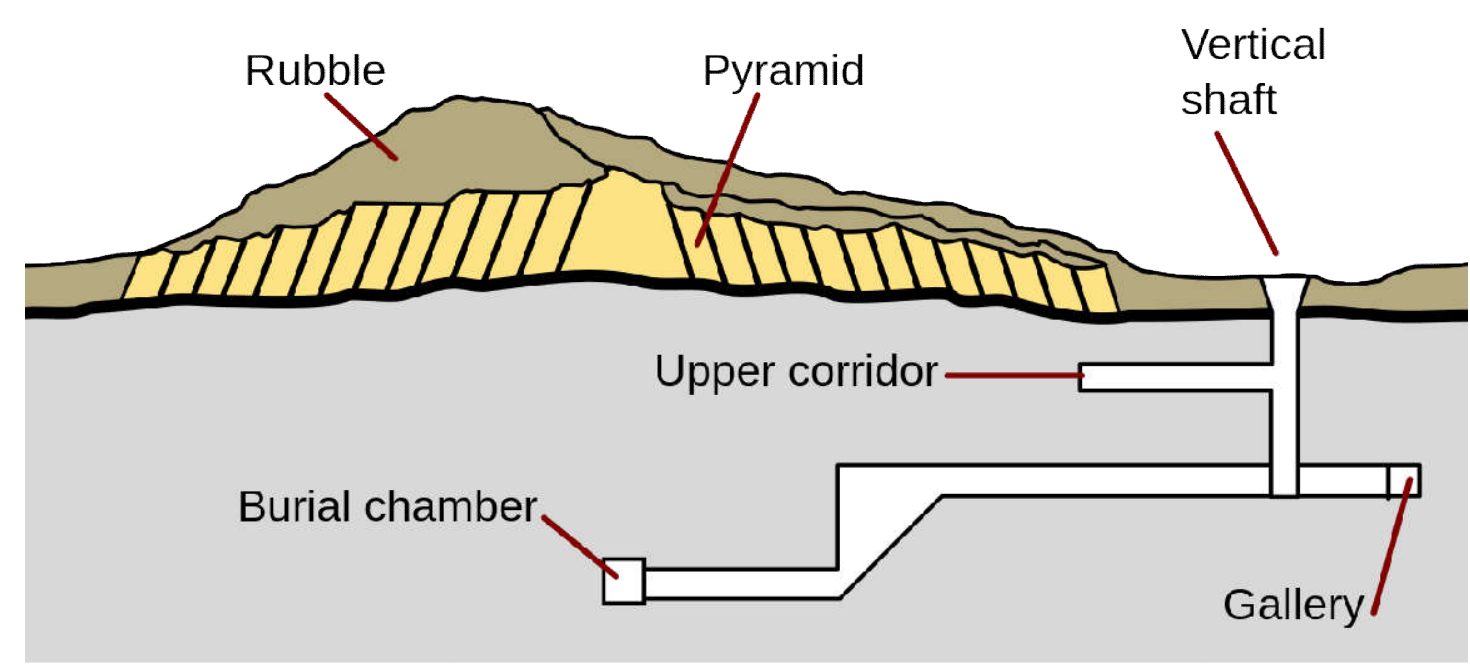

Section of the layer pyramid, showing the substructures

Major pyramids located in Saqqara include the Pyramid of Djosergenerally identified as the world's oldest substantial monumental structure to be built of dressed stone - the Pyramid of Userkaf, the Pyramid of Teti and the Pyramid of Merikare, dating to the First Intermediate Period of Egypt. Also at Saqqara is the Pyramid of Unas, which retains a pyramid causeway that is one of the best-preserved in Egypt. Together with the pyramid of Userkaf, this pyramid was the subject of one of the earliest known restoration attempts, conducted by Khaemweset, a son of Ramesses II. ( Kenneth Kitchen:Ramesside Inscriptions, Translated \& Annotated, Translations, Volume II, Blackwell Publishers, ISBN 0-631-18435-X, 1996). Saqqara is also the location of the incomplete step pyramid of Djoser's successor Sekhemkhet, known as the Buried Pyramid. Archaeologists believe that had this pyramid been 
completed, it would have been larger than Djoser's.

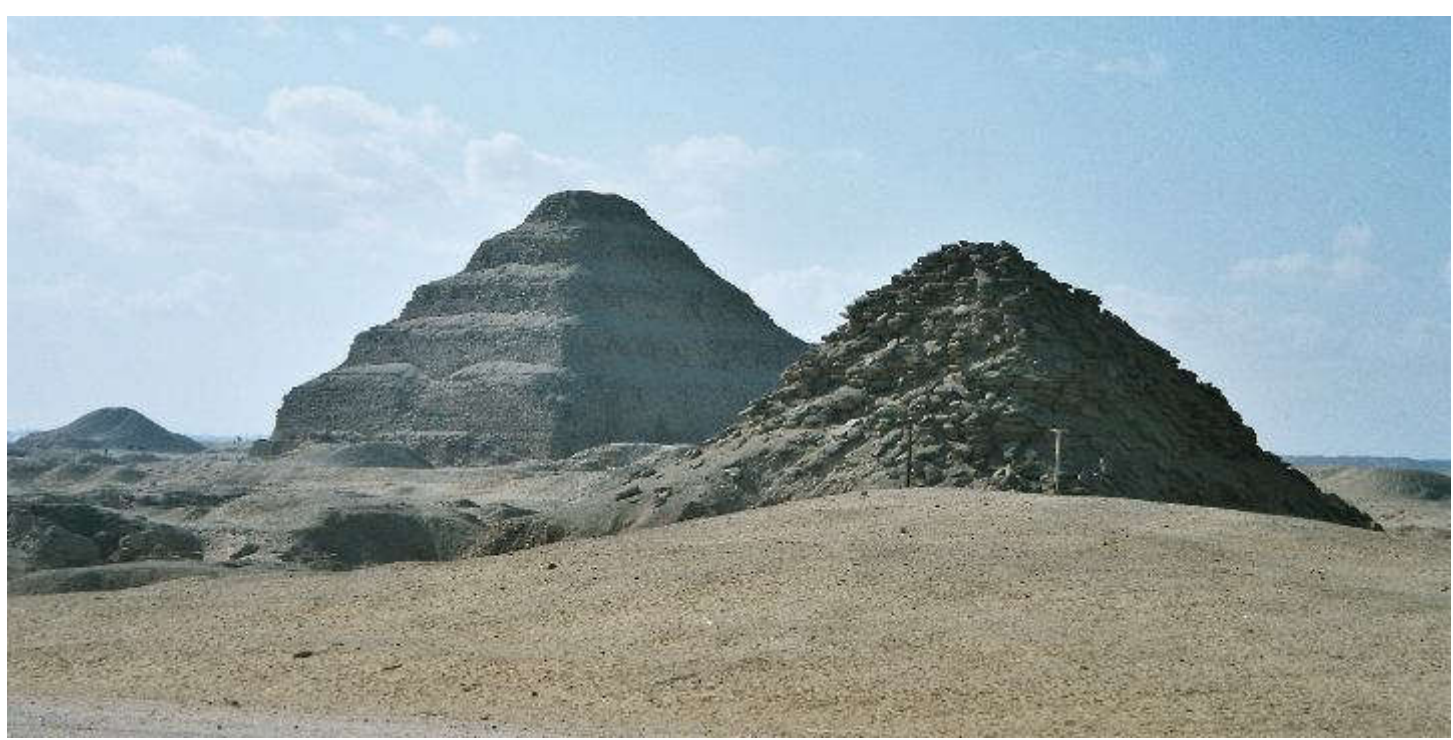

View of Saqqara necropolis, including Djoser's step pyramid (centre), the Pyramid of Unas (left) and the Pyramid of Userkaf (right)

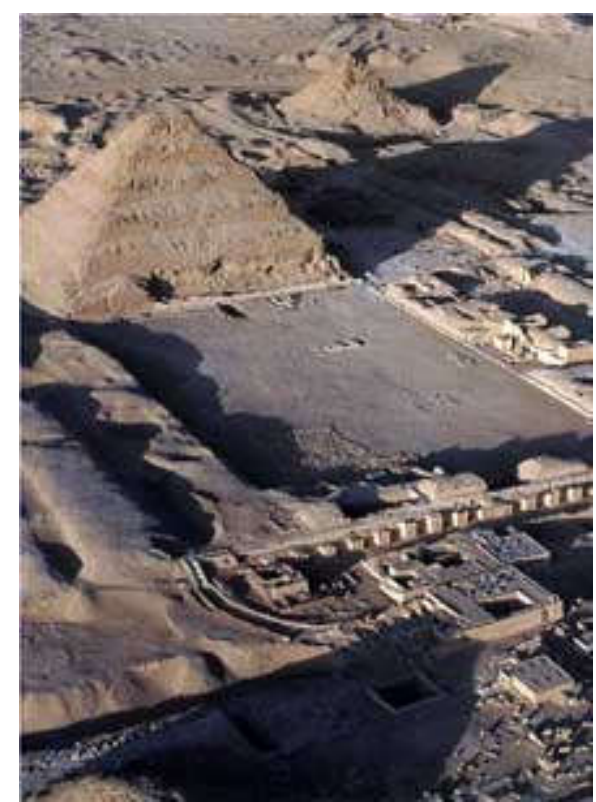

Saqqara: the funerary complex of Djoser: general view. In the background, the pyramid of Userkaf. (Ancient Egypt website) 


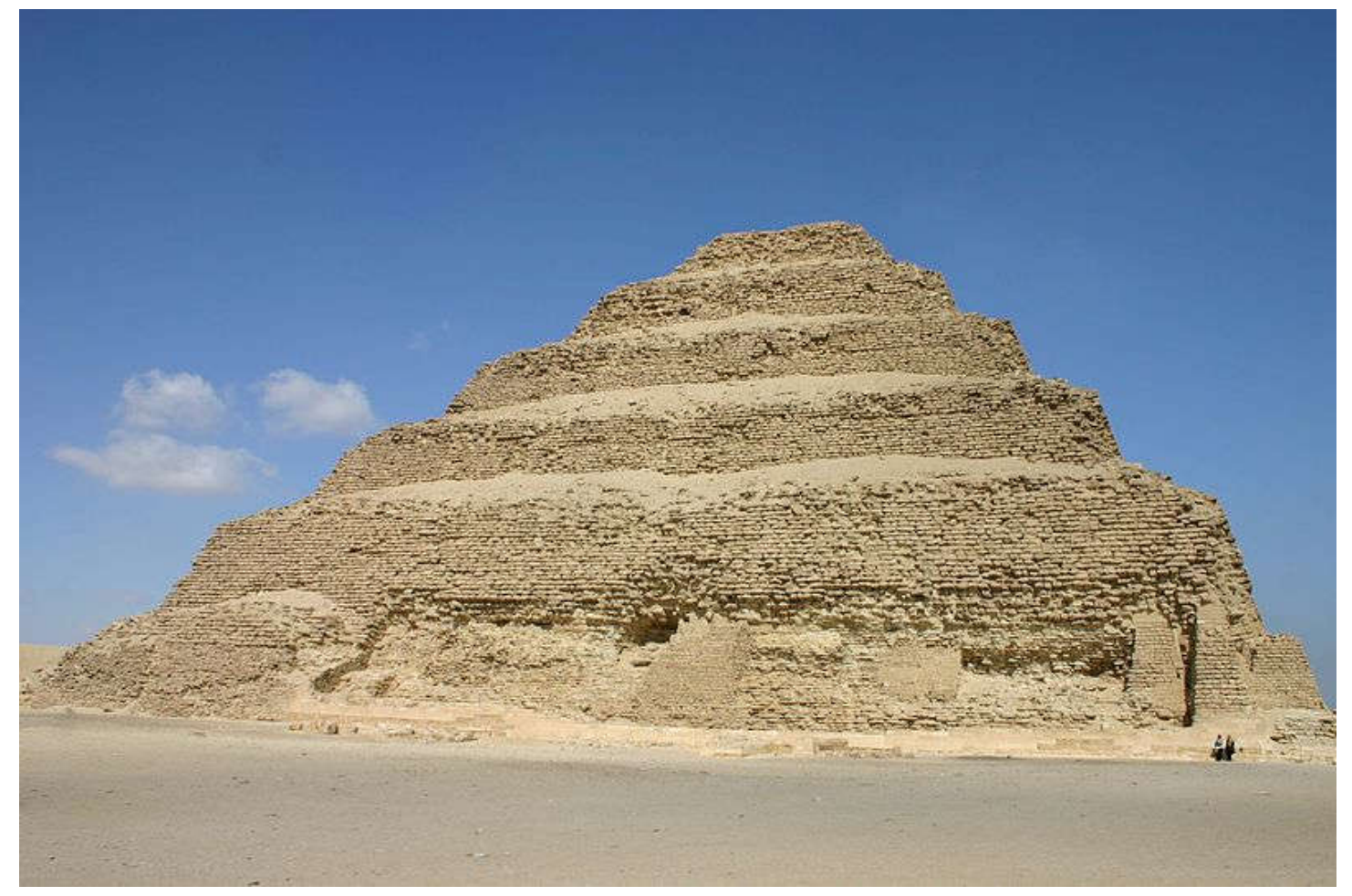

The Pyramid of Djoser

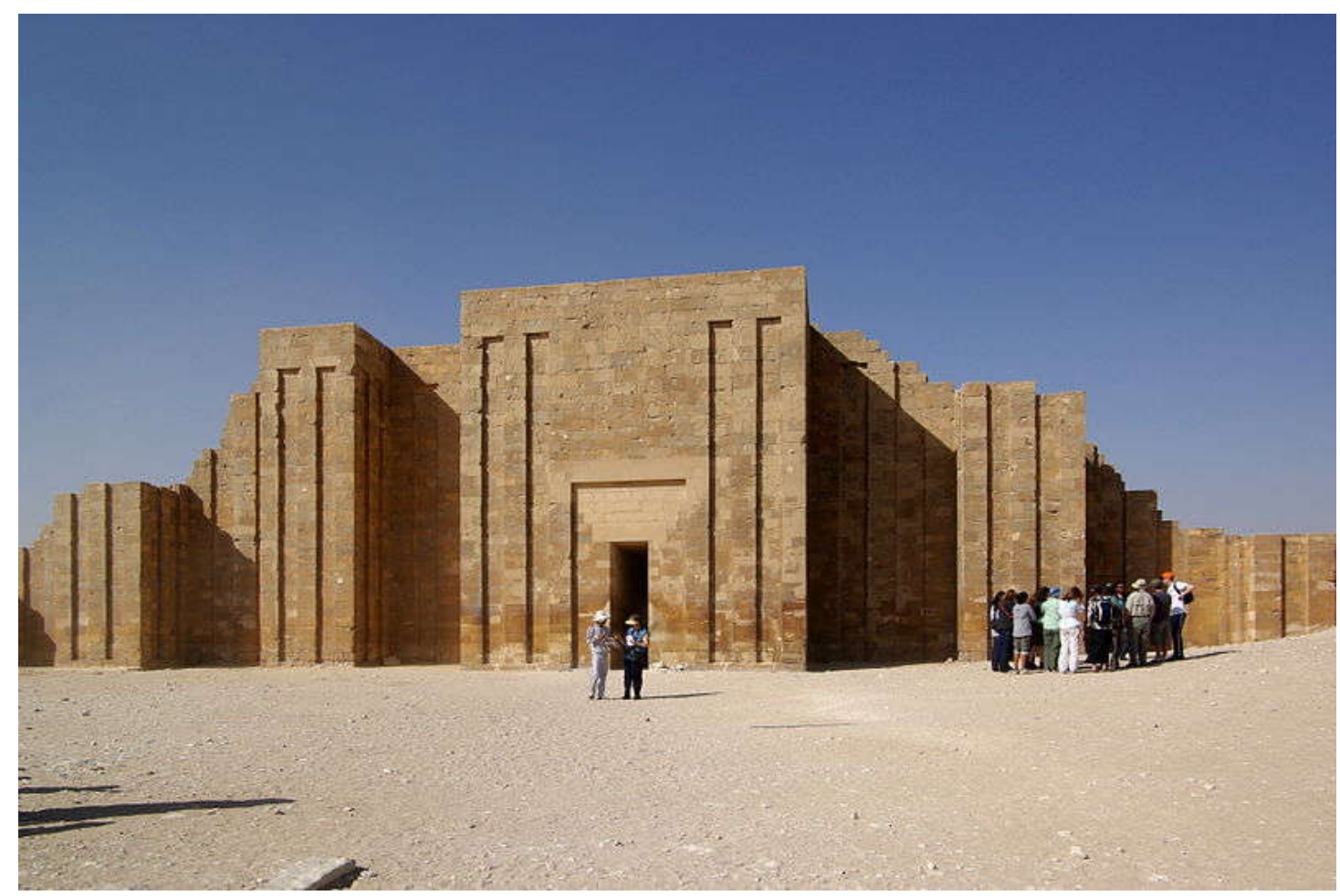

Funerary complex of Djoser 


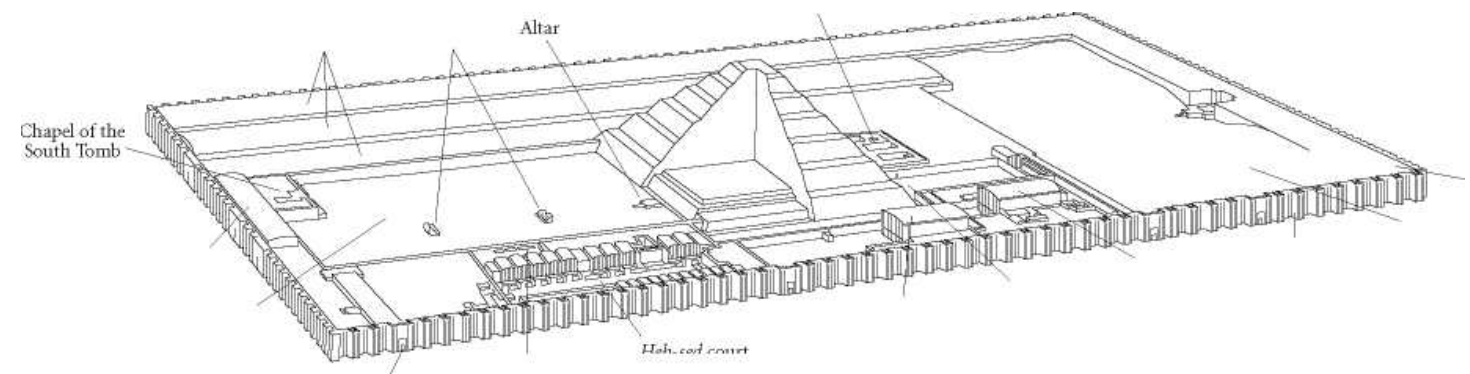

Djoser's Step Pyramid complex, Saqqara.

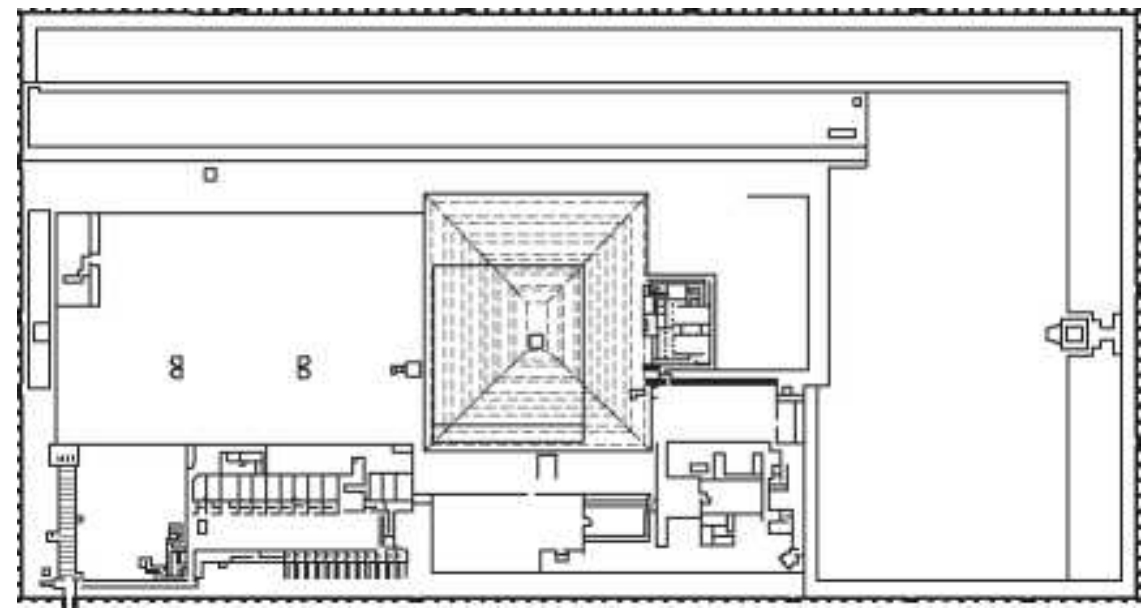

Djoser's Step Pyramid complex, Saqqara. Source: Mark Lehner, The Complete Pyramids. London: Thames and Hudson, 1997, p. 85

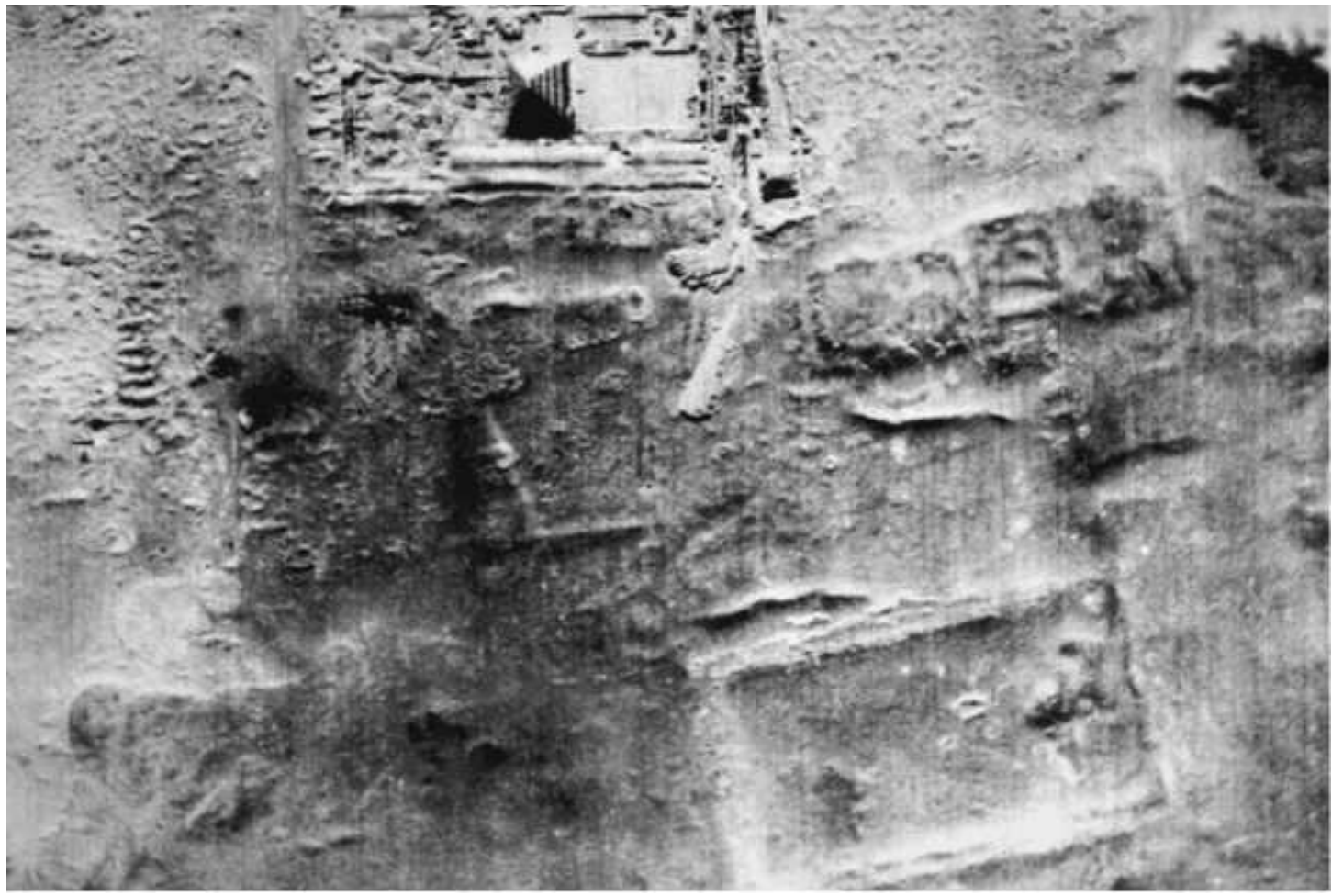

Aerial photo of the Step Pyramid complex and three unfinished rectangular pyramid complexes at Saqqara, from old RAF aerial photographs taken in 1947. Courtesy of 
the Saqqara Geophysical Survey Project

South of the main pyramid field at Saqqara is a second collection of later, smaller pyramids, including those of Pepi I, Djedkare Isesi, Merenre, Pepi II and Ibi. Most of these are in a poor state of preservation.

The Fourth Dynasty pharaoh Shepseskaf either did not share an interest in, or have the capacity to undertake pyramid construction like his predecessors. His tomb, which is also sited at south Saqqara, was instead built as an unusually large mastaba and offering temple complex. It is commonly known as the Mastabat al-Fir'aun. (The Mastaba of Shepseskaf).

A previously unknown pyramid was discovered at north Saqqara in late 2008. Believed to be the tomb of Teti's mother, it currently stands approximately $5 \mathrm{~m}$ (16 ft) high, although the original height was closer to $14 \mathrm{~m}(46 \mathrm{ft})$.

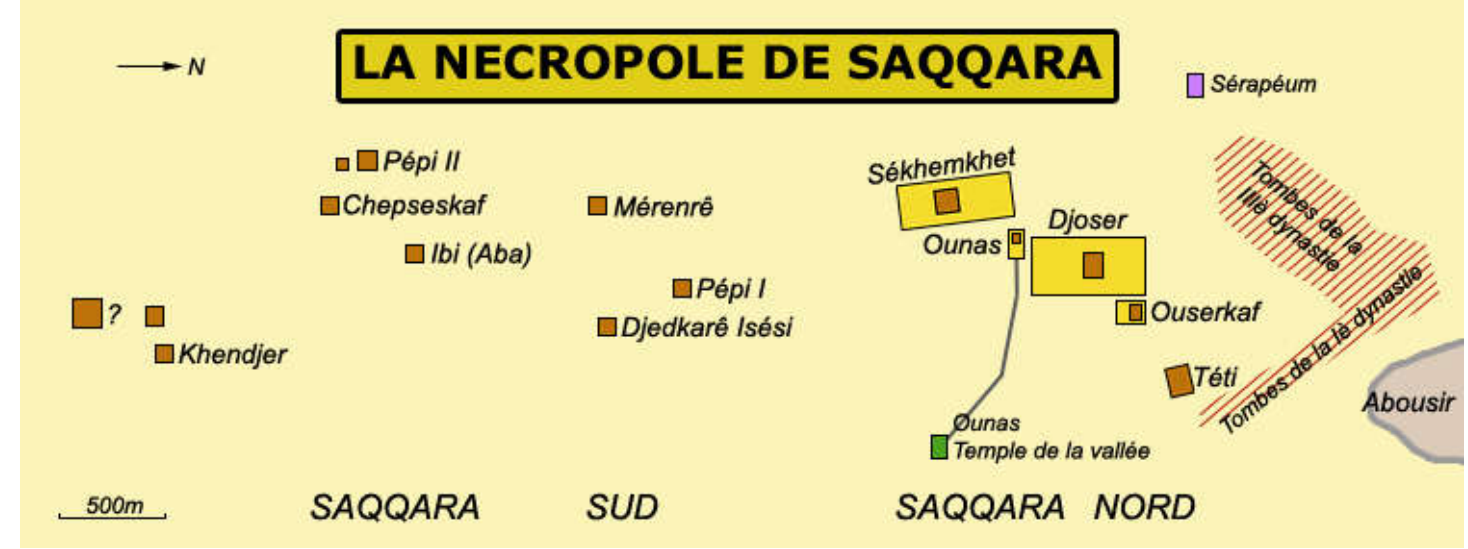

Saqqara: general plan of the northern group and the southern group. (Ancient Egypt website) 


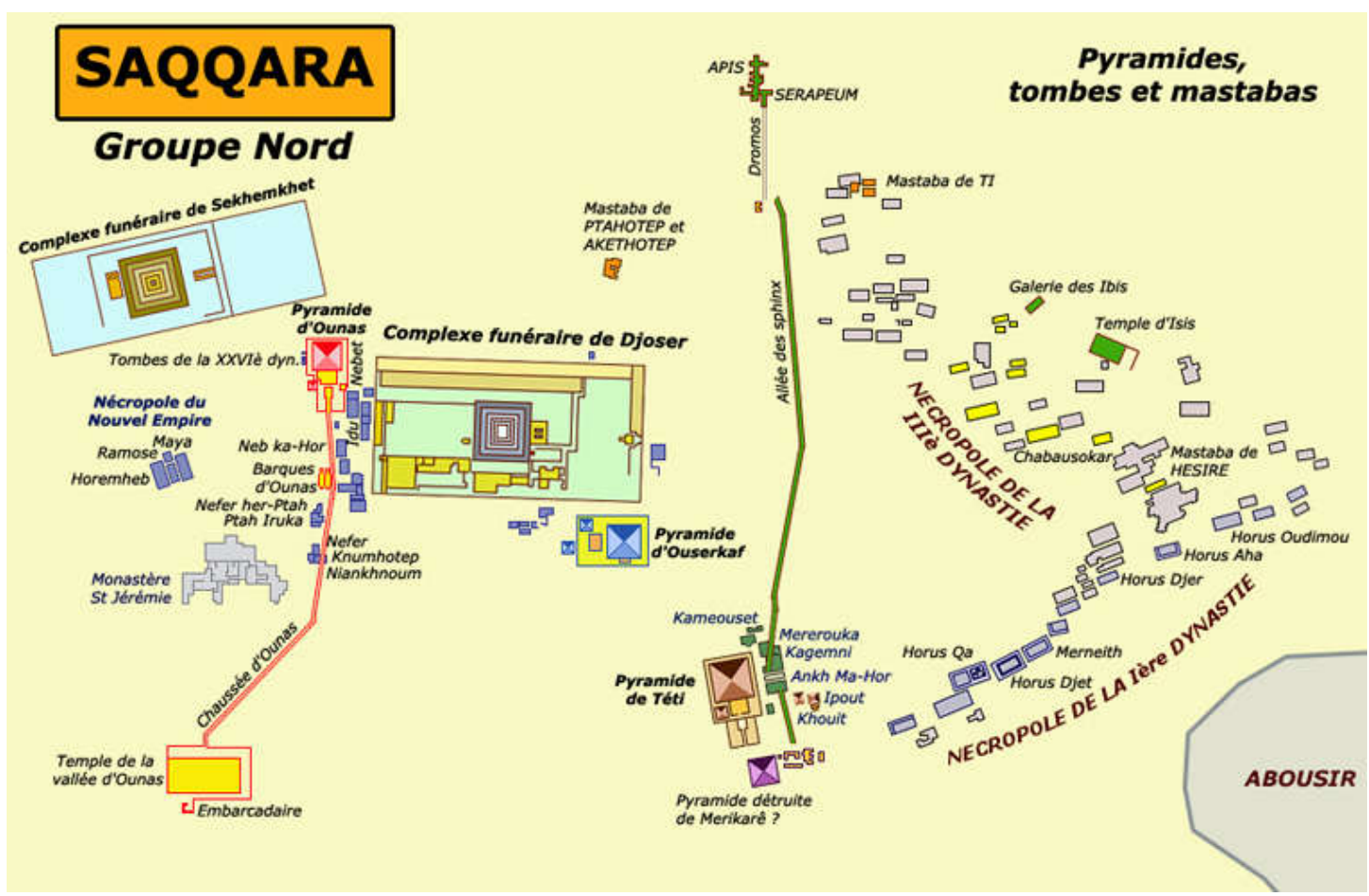

Saqqara: general plan of the northern group with the necropolis of the Thinite and Old Kingdom periods. (Ancient Egypt website)

Dahshur is arguably the most important pyramid field in Egypt outside Giza and Saqqara, although it was relatively unknown outside archaeological circles.

The southern Pyramid of Sneferu, commonly known as the Bent Pyramid, is believed to be the first Egyptian pyramid intended by its builders to be a "true" smooth-sided pyramid from the outset; the earlier pyramid at Meidum had smooth sides in its finished state - but it was conceived and built as a step pyramid, before having its steps filled in and concealed beneath a smooth outer casing of dressed stone. As a true smooth-sided structure, the Bent Pyramid was only a partial success - albeit a unique, visually imposing one; it is also the only major Egyptian pyramid to retain a significant proportion of its original smooth outer 
limestone casing intact. As such it serves as the best contemporary example of how the ancient Egyptians intended their pyramids to look. Several kilometers to the north of the Bent Pyramid is the last - and most successful - of the three pyramids constructed during the reign of Sneferu; the Red Pyramid is the world's first successfully completed smooth-sided pyramid. The structure is also the third largest pyramid in Egypt - after the pyramids of Khufu and Khafra at Giza.

Also at Dahshur is one of two pyramids built by Amenemhat III, known as the Black Pyramid, as well as a number of small, mostly ruined subsidiary pyramids.

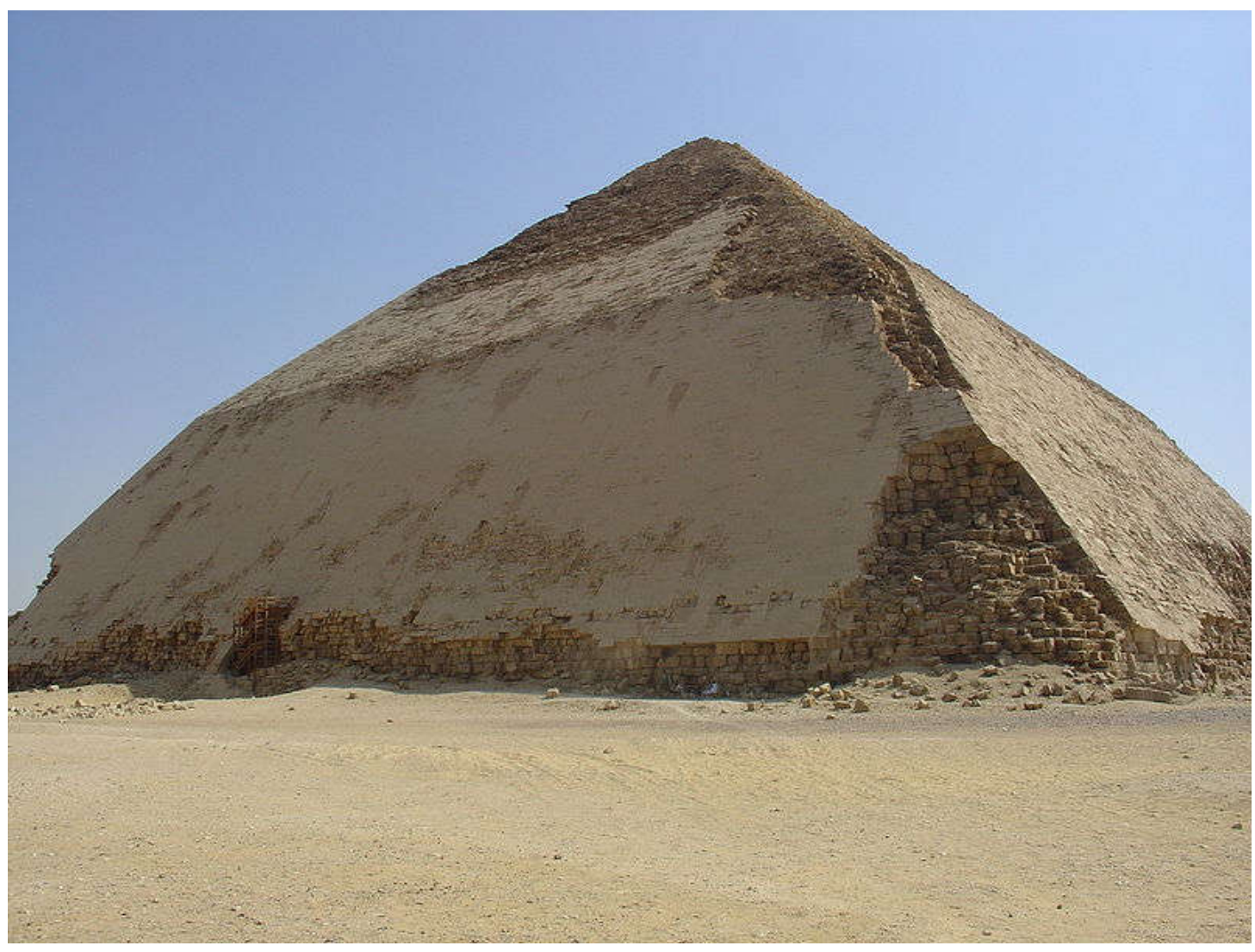

Sneferu's Bent Pyramid in Dahshur 


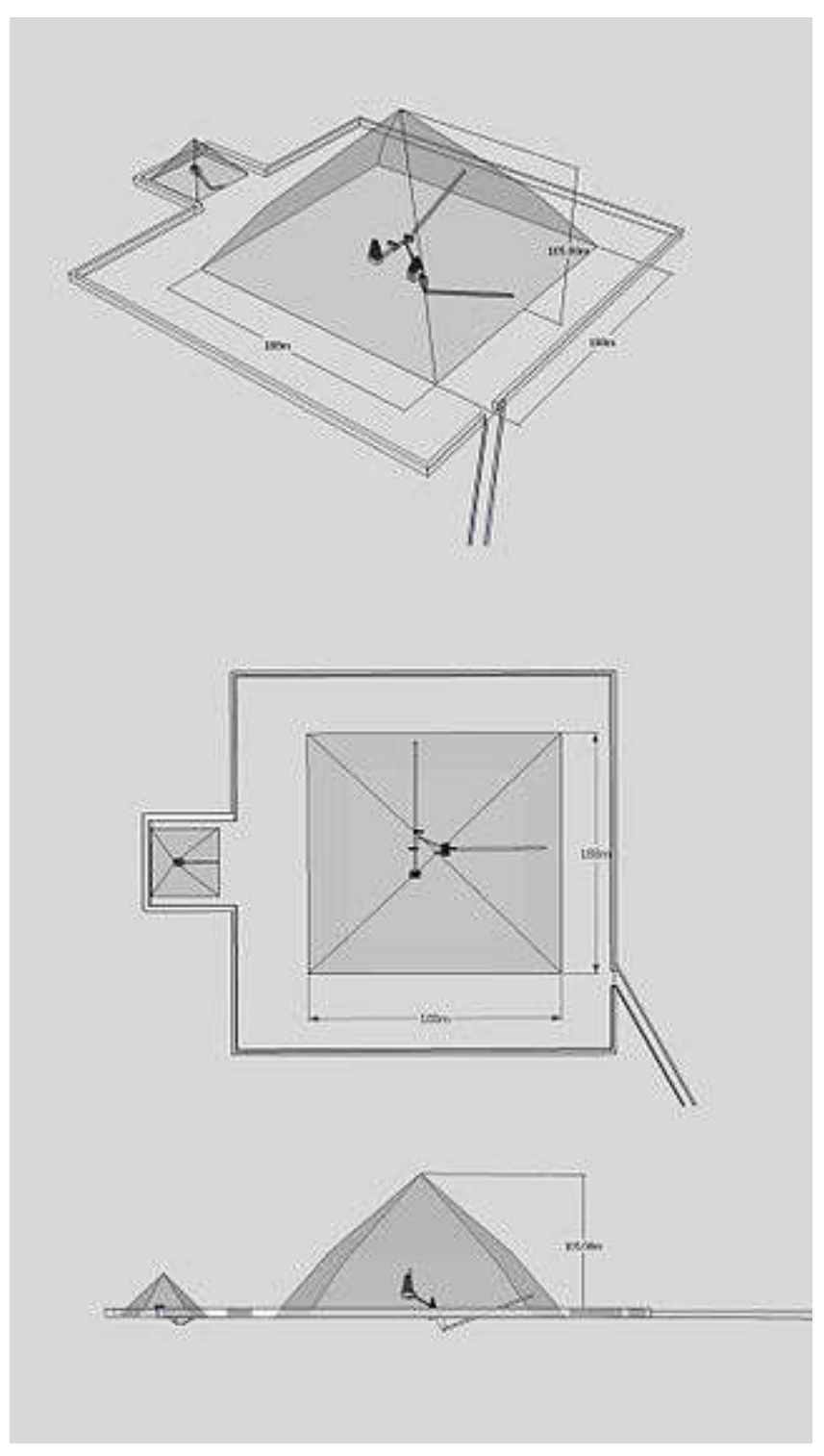

Isometric, plan and elevation images of the Bent Pyramid Complex taken from a $3 d$ model 


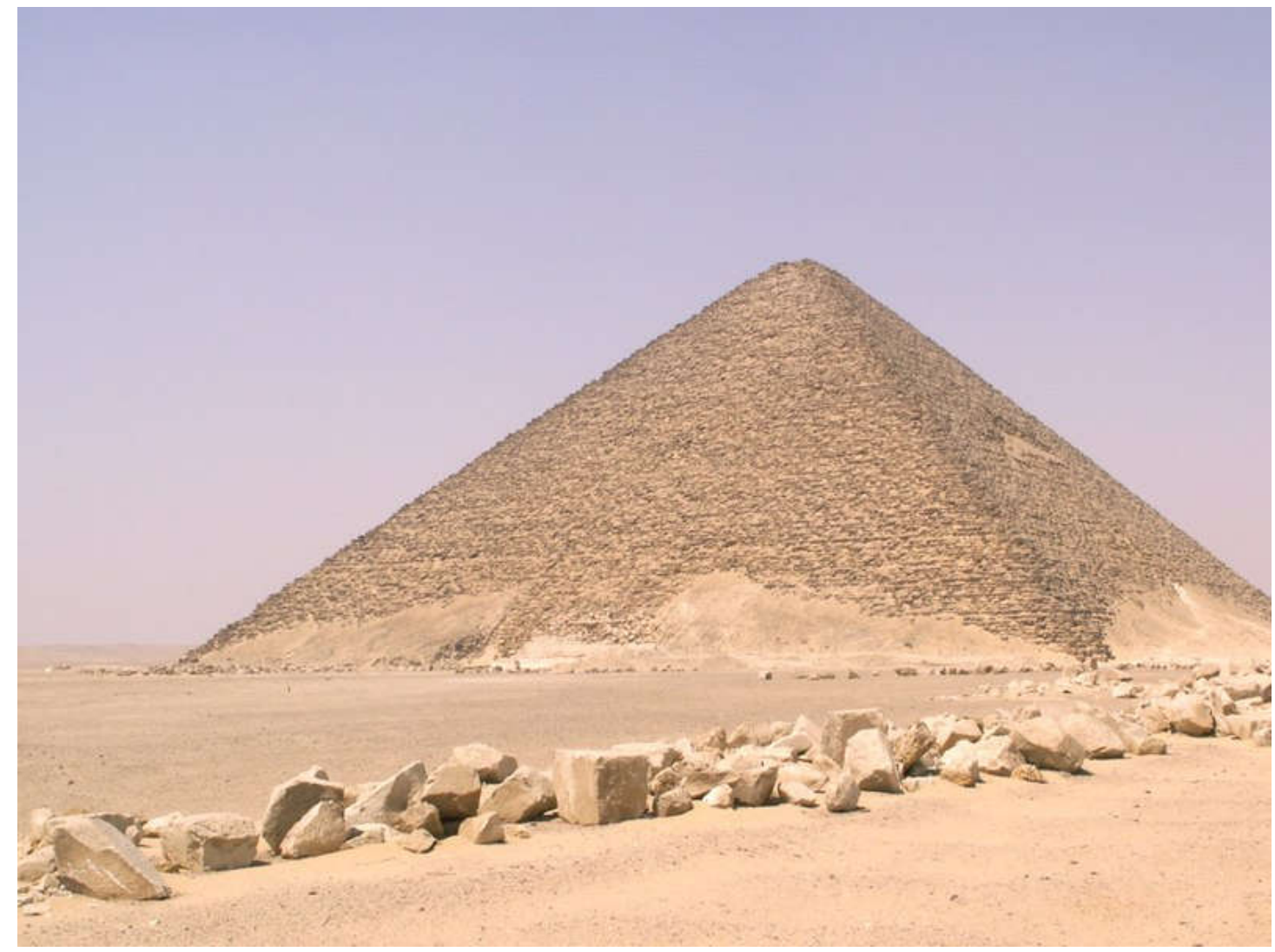

Sneferu's Red Pyramid 


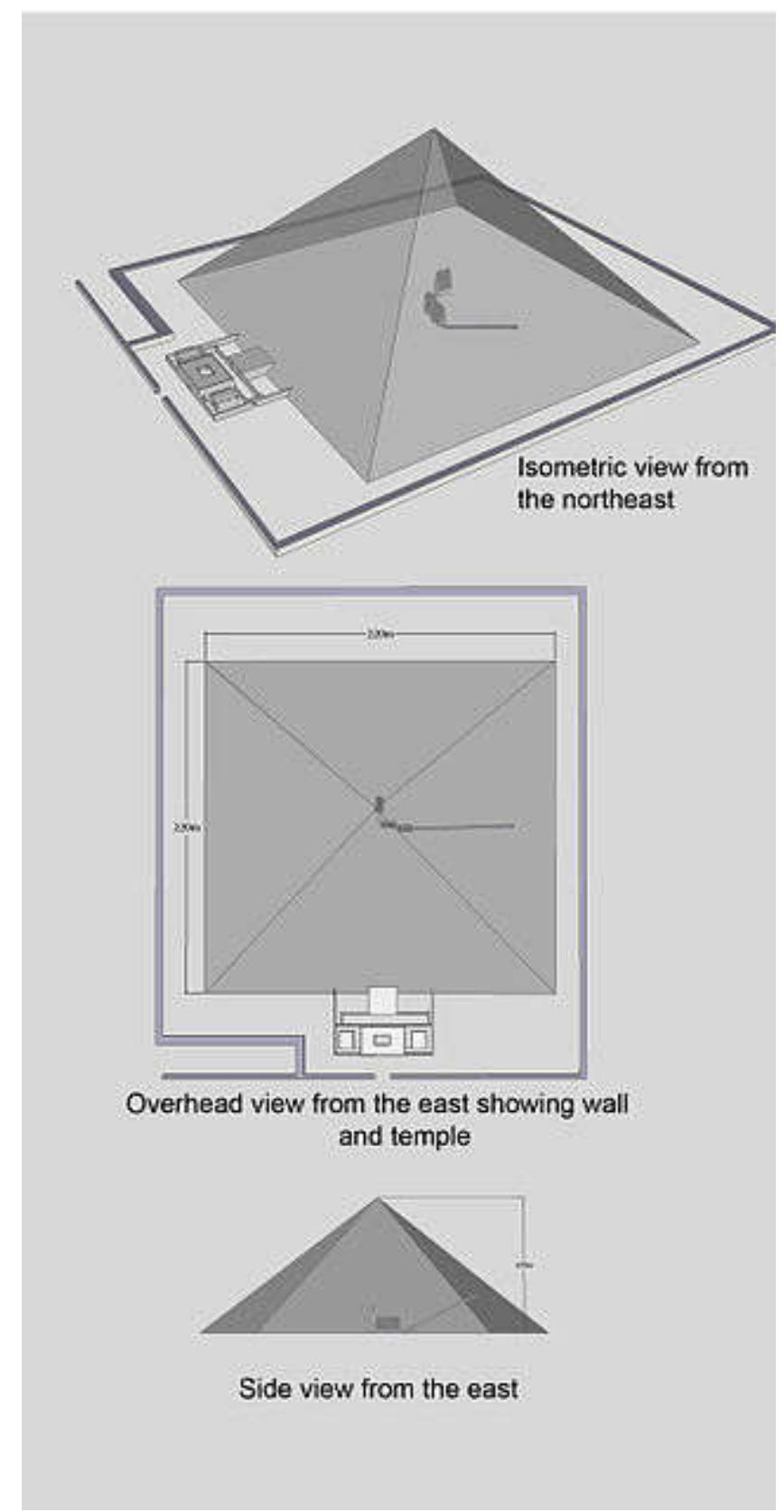

Isometric, plan and elevation images of the Red Pyramid Complex taken from a 3D model 


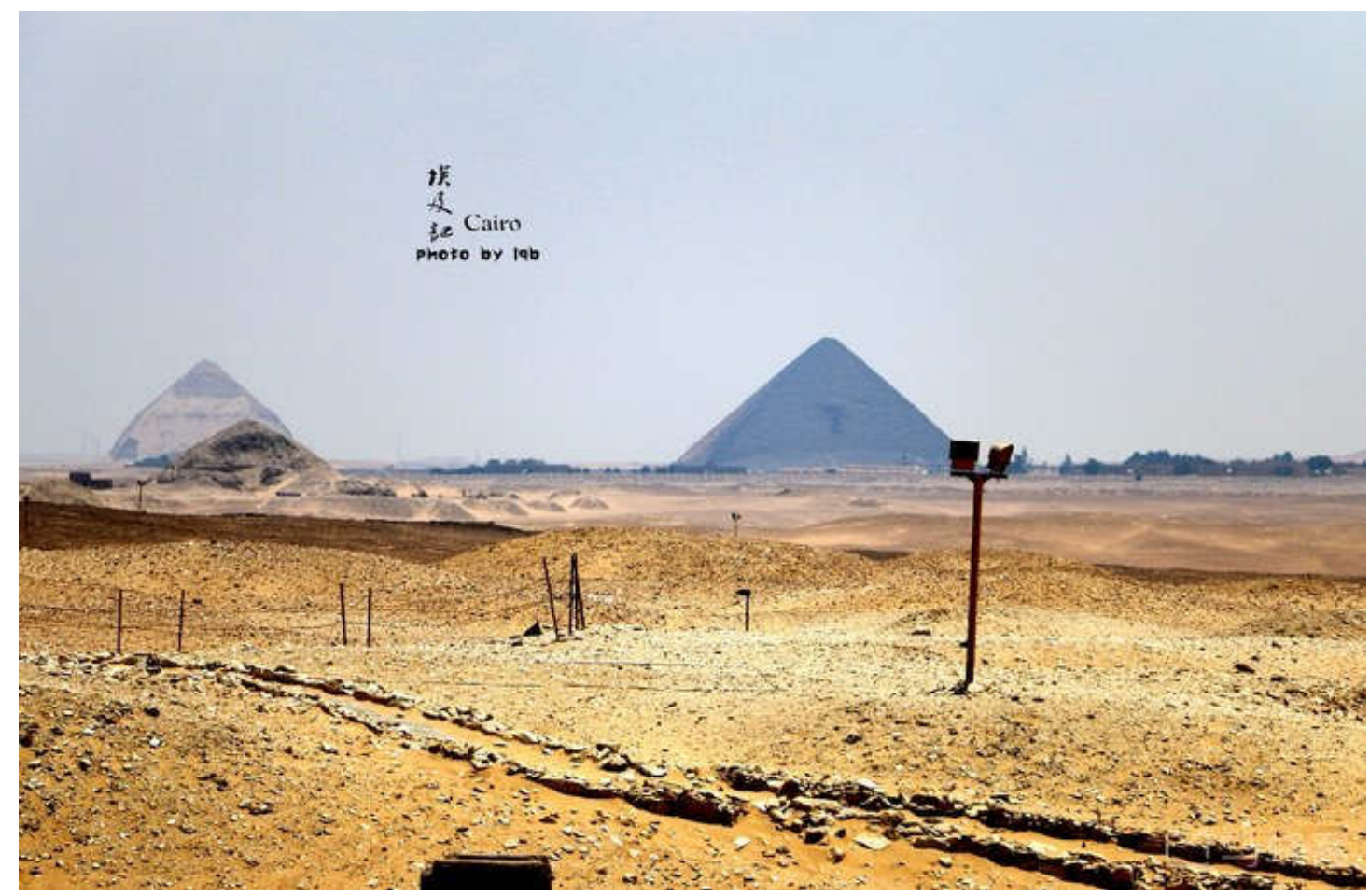

An overlook of Red Pyramid and Bent Pyramid of Dahshur, from Saqqara

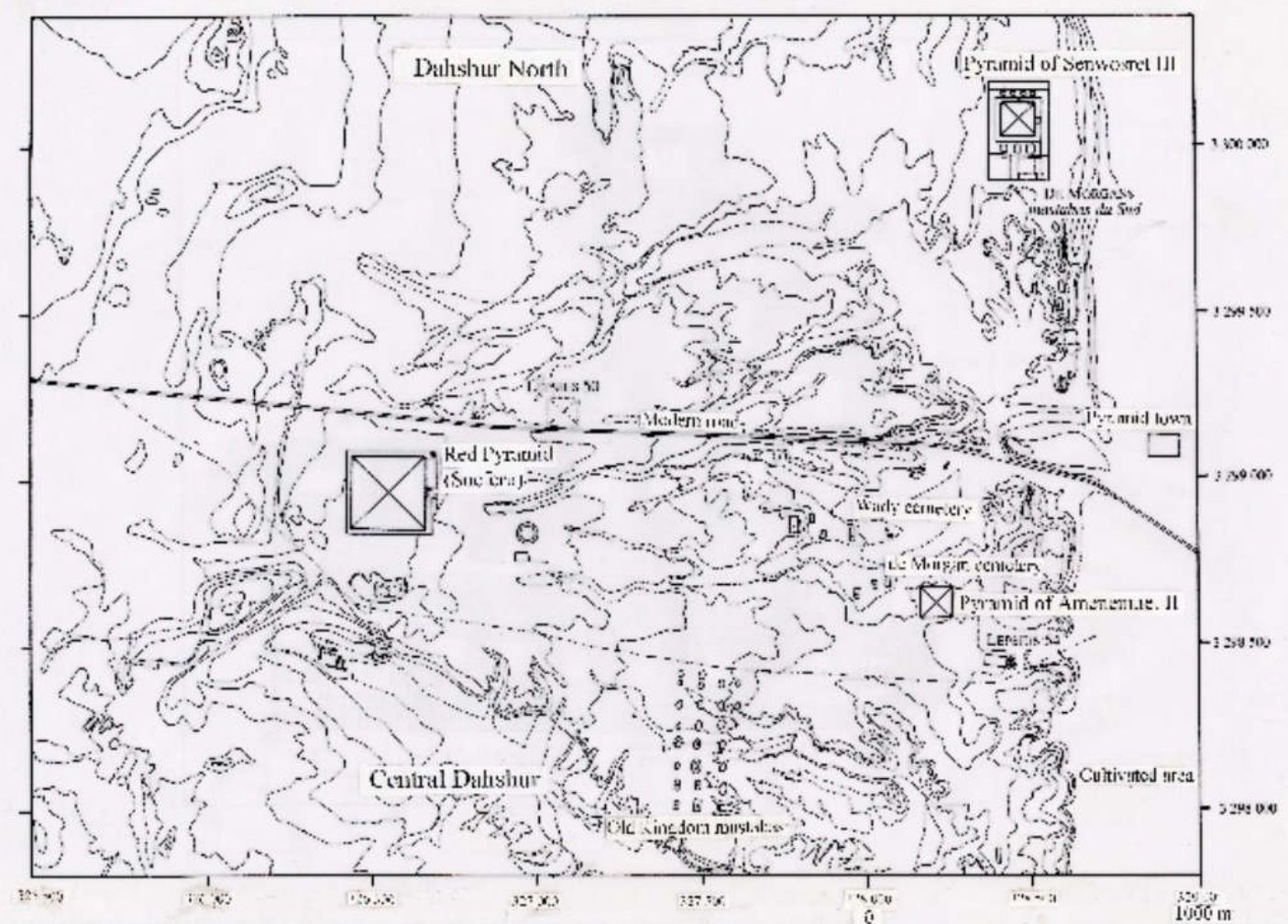

General map of the site of Dahshur 


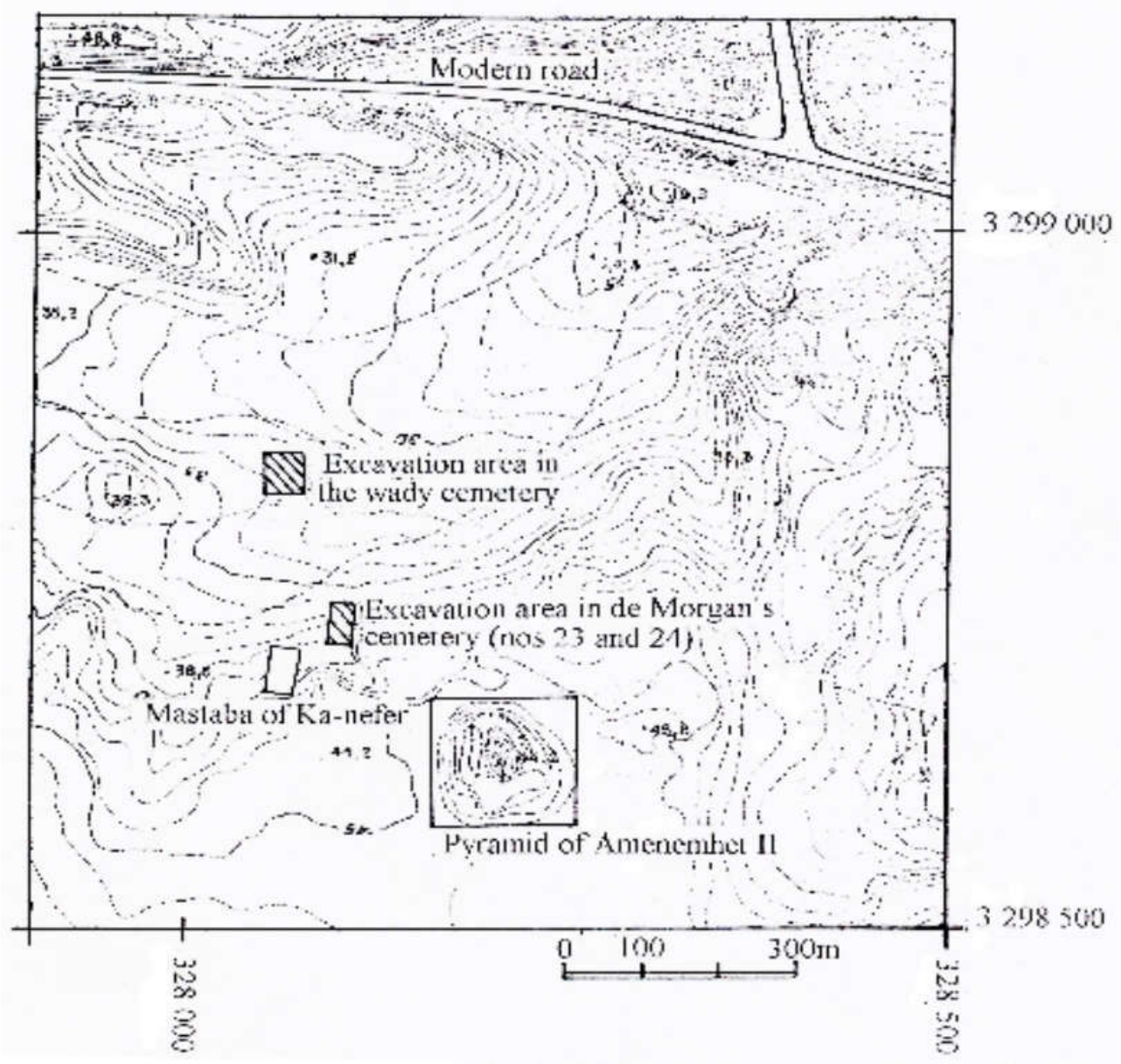

Detailed map of the site of Dahshur 


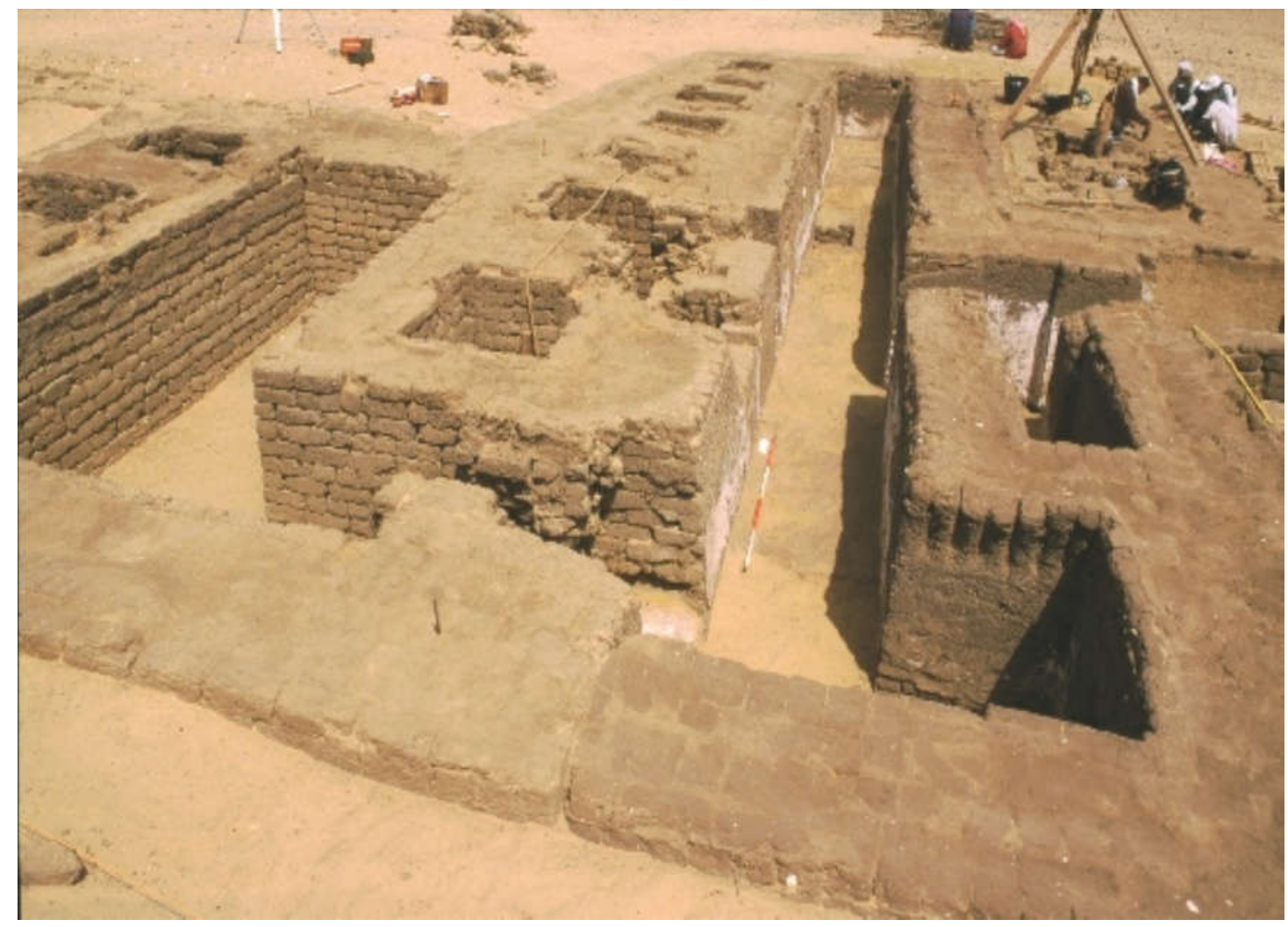

View of the great mastaba in the wady cemetery of Dahshur; view from the southeast.

The following table lays out the chronology of the construction of most of the major pyramids mentioned above. Each pyramid is identified through the pharaoh who ordered it built, his approximate reign, and its location. 


\begin{tabular}{|c|c|c|c|}
\hline $\begin{array}{l}\text { Pyramid / } \\
\text { Pharaoh }\end{array}$ & Reign & Field & Height \\
\hline Djoser & c. $2670 \mathrm{BC}$ & Saqqara & 62 meters (203 feet) \\
\hline Sneferu & $\begin{array}{l}\text { C. } 2612-2589 \\
\text { BC }\end{array}$ & Dashur & 104 meters (341 feet) \\
\hline Sneferu & $\begin{array}{l}\text { C. } 2612-2589 \\
\text { BC }\end{array}$ & Meidum & $\begin{array}{l}65 \text { meters ( } 213 \text { feet) (ruined) } \\
\text { *Would have been } 91.65 \text { meters }(301 \\
\text { feet) or } 175 \text { Egyptian Royal cubits. }\end{array}$ \\
\hline Khufu & $\begin{array}{l}\text { C. } 2589-2566 \\
\text { BC }\end{array}$ & Giza & $\begin{array}{l}146.7 \text { meters (481 feet) or } 280 \\
\text { Egyptian Royal cubits }\end{array}$ \\
\hline Djedefre & $\begin{array}{l}\text { C. } 2566-2558 \\
\text { BC }\end{array}$ & $\begin{array}{l}\text { Abu } \\
\text { Rawash }\end{array}$ & 60 meters (197 feet) \\
\hline Khafre & $\begin{array}{l}\text { C. } 2558-2532 \\
\text { BC }\end{array}$ & Giza & $\begin{array}{l}136.4 \text { meters ( } 448 \text { feet) } \\
\text { *Originally: } 143.5 \text { m or } 471 \text { feet or } 274 \\
\text { Egyptian Royal cubits }\end{array}$ \\
\hline Menkaure & $\begin{array}{l}\text { C. } 2532-2504 \\
\text { BC }\end{array}$ & Giza & $\begin{array}{l}65 \text { meters ( } 213 \text { feet) or } 125 \text { Egyptian } \\
\text { Royal cubits }\end{array}$ \\
\hline Userkaf & $\begin{array}{l}\text { C. } 2494-2487 \\
\text { BC }\end{array}$ & Saqqara & 48 meters (161 feet) \\
\hline Sahure & $\begin{array}{l}\text { C. } 2487-2477 \\
\text { BC }\end{array}$ & Abusir & 47 meters (155 feet) \\
\hline $\begin{array}{c}\text { Neferirkare } \\
\text { Kakai }\end{array}$ & $\begin{array}{l}\text { C. } 2477-2467 \\
\text { BC }\end{array}$ & Abusir & 72.8 meters (239 feet) \\
\hline Nyuserre Ini & $\begin{array}{l}\text { C. } 2416-2392 \\
\text { BC }\end{array}$ & Abusir & $\begin{array}{l}51.68 \text { m ( } 169.6 \text { feet) or } 99 \text { Egyptian } \\
\text { Royal cubits }\end{array}$ \\
\hline Amenemhat I & $\begin{array}{l}\text { C. } 1991-1962 \\
\text { BC }\end{array}$ & Lisht & 55 meters ( 181 feet) \\
\hline Senusret I & $\begin{array}{l}\text { C. } 1971-1926 \\
\text { BC }\end{array}$ & Lisht & 61.25 meters (201 feet) \\
\hline Senusret II & $\begin{array}{l}\text { c. } 1897-1878 \\
\text { BC }\end{array}$ & el-Lahun & $\begin{array}{l}48.65 \mathrm{~m} \quad(159.6 \mathrm{ft} ; 93 \text { Egyptian } \\
\text { Royal cubits) or }\end{array}$ \\
\hline
\end{tabular}




\begin{tabular}{|c|c|c|c|}
\hline & & & $\begin{array}{l}47.6 \text { m (156 ft; } 91 \text { Egyptian } \\
\text { Royal cubits) }\end{array}$ \\
\hline Amenemhat III & $\begin{array}{l}\text { C. } 1860-1814 \\
\text { BC }\end{array}$ & Hawara & 75 meters (246 feet) \\
\hline Khendjer & $\begin{array}{l}\text { C. } 1764-1759 \\
\text { BC }\end{array}$ & Saqqara & $\begin{array}{l}37.35 \mathrm{~m} \text { (122.5 feet), now } 1 \mathrm{~m}(3.3 \\
\text { feet) }\end{array}$ \\
\hline Piye & c. $721 \mathrm{BC}$ & El-Kurru & $\begin{array}{l}20 \text { meters (66 feet) or } \\
30 \text { meters (99 feet) }\end{array}$ \\
\hline Taharqa & c. $664 \mathrm{BC}$ & Nuri & $\begin{array}{l}40 \text { meters (132 feet) or } \\
50 \text { meters (164 feet) }\end{array}$ \\
\hline
\end{tabular}

Hyperdiffusionism refers to hypotheses suggesting that certain historical technologies or ideas originated with a single people or civilization before their adoption by other cultures. Thus, all great civilizations that share similar cultural practices, such as construction of pyramids, derived them from a single common progenitor. According to its proponents, examples of hyperdiffusion can be found in religious practices, cultural technologies, megalithic monuments, and lost ancient civilizations.

Heliolithic Culture, as Grafton Elliot Smith refers to it, consists of cultural practices such as megaliths. Similar designs and methods of construction of such pieces have what seem like a linear geographical distribution. These heliolithic cultures can refer to religious customs that share distinctive practices, such as the worship of a Solar Deity. As this trope is seen in numerous belief systems, Smith believes it is diffused from one ancient civilization (Smith 1929, p. 132). 
Mummification, as believed by G. Elliot Smith, is a prime example of how religious customs prove the diffusion of cultures (Smith 1929, 21). He believes that only an advanced civilization, such as Egypt, could create such a peculiar belief that then spread by way of ancient mariners (Smith 1929, 133-134).

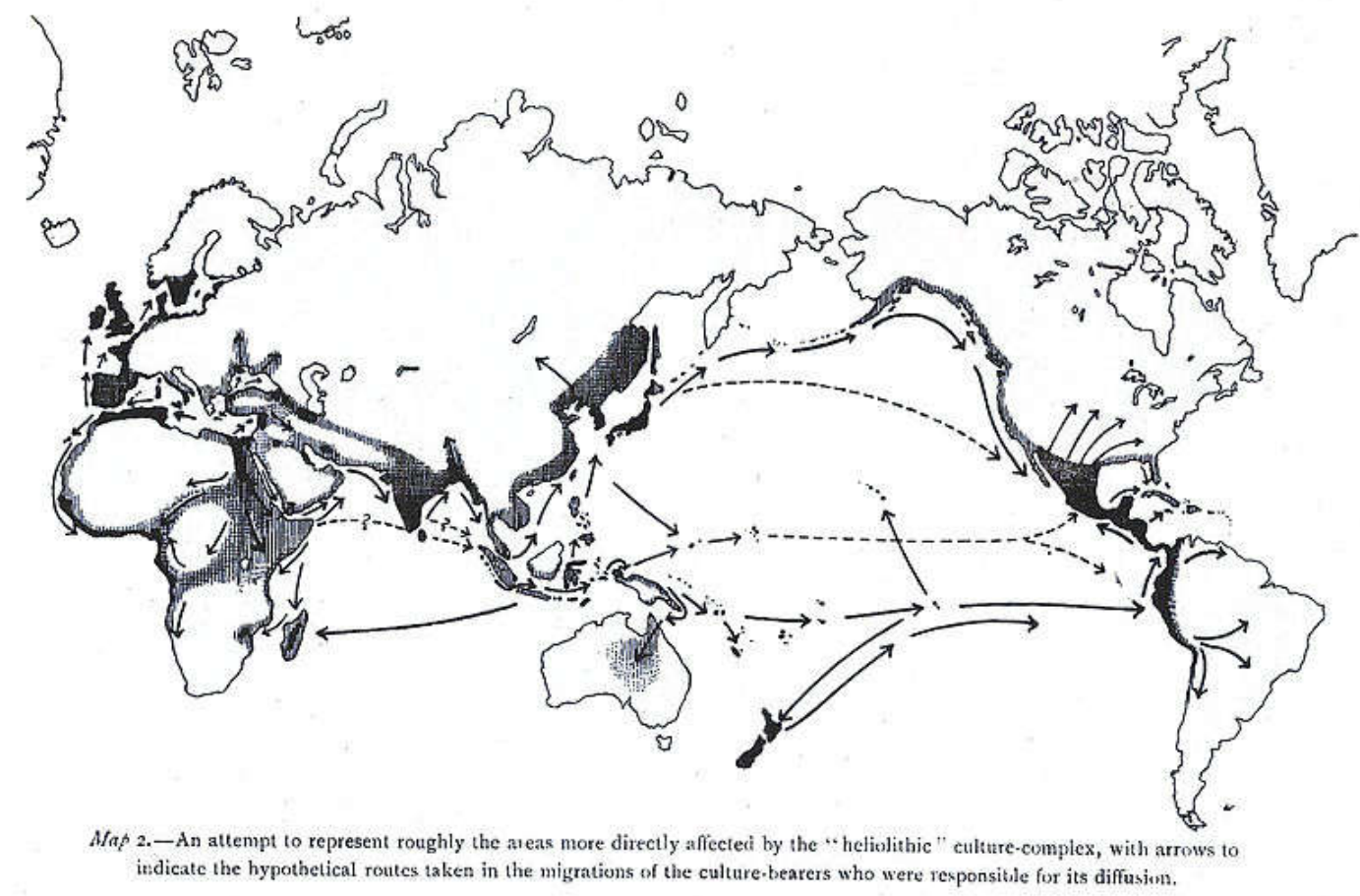

Grafton Elliot Smith: Map of Hyperdiffusionism from Egypt, 1929

And Haplogroup Q or Q-M242 is a Y-chromosome DNA haplogroup. It has one primary subclade, Haplogroup Q1 (L232/S432), which includes numerous subclades that have been sampled and identified in males among modern populations. In my point of view, the speculation of migration of Haplogroup $Q$ is the following below: 


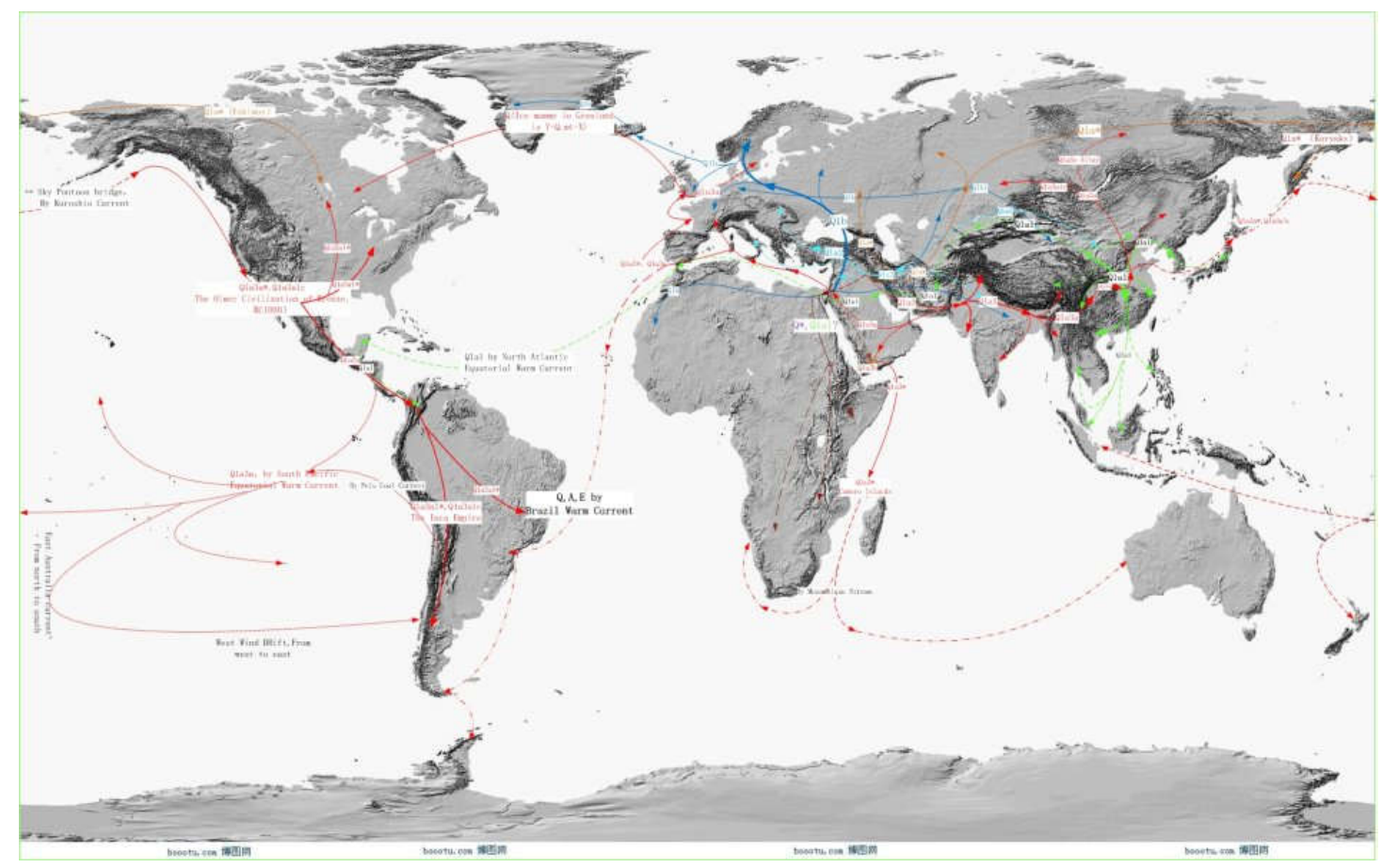

The speculation of migration of Haplogroup $Q$

The subclades of Haplogroup Q with their defining mutation(s), according to the 2011 ISOGG tree are provided below.

- Q M242

- Q1 P36.2, L232, L273, L274

- Q1a MEH2

- Q1a1 M120, M265/N14

- Q1a2 M25, M143

- Q1a3 L56, L57, M346, L528

- Q1a3a L53, L54, L55, L213, L331

- Q1a3a1 M3

- Q1a3a1a M19

- Q1a3a1b M194

- Q1a3a1c M199, P106, P292

- Q1a3a2 L191

- Q1a3a3 L330, L334

- Q1a3a3a L329, L332, L333

- Q1a3b M323

- Q1a3c L527, L529

- Q1b L275, L314

- Q1b1 M378/Page100, L214, L215/Page82

- Q1b1a L245

- Q1b1a1 L272.1 
And that is the information of Egyptian Gene:

\author{
The Egyptian Gene \\ Although not detected in the royal \\ mummies whose DNA has been examined \\ so far, this autosomal ancestry marker is \\ also clearly African in origin. Today it \\ enjoys its greatest spread in Egyptians. \\ About 1 in 10 Africans or African \\ Americans have it, but a sharp spike \\ occurs in Copts, today's successor \\ population in the Land of the Nile, where \\ up to $27 \%$ possess it. About $7 \%$ of \\ European Americans have it. Tellingly \\ perhaps, East Coast Indians and \\ Melungeons have it at elevated levels. It is \\ hardly noticeable in Asia, suggesting that it \\ did not form a significant part of the Great \\ Migration of Humanity out of Africa about \\ 100,000 years ago but spread to Eurasian \\ populations primarily from Egypt and the
}

And that is the image of the world ancestry of the Egyptian Gene:

World Ancestry of the Egyptian Gene

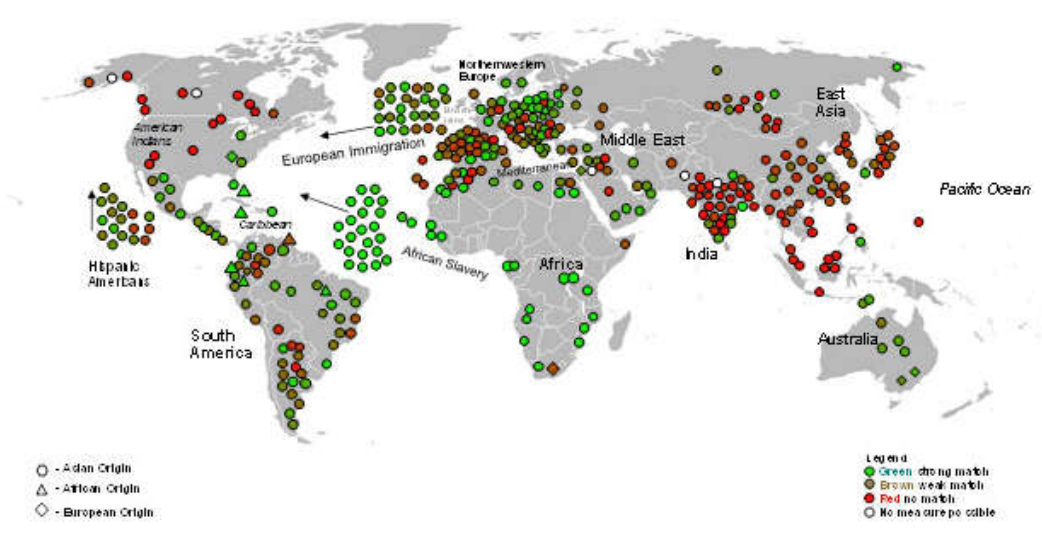

The Egyptian Gene is Sub-Saharan African in origin like others in its series but enjoys a surprising distribution in select populations, including Maya Indians, Northeast Europeans, Melungeons and Jews.

All Contents Copyright (c) 2012, DNA Consultants, Phoenix

In the image above, green circle means strong match, brown means weak match, red means no match, transparent means no match possible. Notice that China also has a certain mark of this Egyptian Gene.(In the 
area of ancient Liangzhu Culture (良渚文化)).

Listed below are the human Y-chromosome DNA haplogroups found in various ethnic groups and populations from Africa .

\begin{tabular}{|c|c|c|c|c|c|c|c|c|c|c|c|c|c|c|c|c|c|c|c|c|c|c|c|c|c|c|c|c|c|}
\hline Country ${ }^{[1]}$ & $\mathrm{n}$ & $\Delta$ & B & $\begin{array}{l}\text { E- } \\
\text { I33 }\end{array}$ & E-I2 & $\begin{array}{c}\mathrm{E}- \\
\text { I35* }\end{array}$ & $\begin{array}{c}\text { E- } \\
\text { I } 78^{*}\end{array}$ & $\begin{array}{c}\mathrm{E}- \\
\mathrm{712}\end{array}$ & $\begin{array}{c}\text { E- } \\
\text { 732 }\end{array}$ & $\begin{array}{c}\mathrm{E}- \\
\mathrm{713}\end{array}$ & $\begin{array}{c}\text { E- } \\
\text { T22 }\end{array}$ & $\begin{array}{c}\mathrm{E}^{-} \\
765\end{array}$ & $\begin{array}{l}\text { E- } \\
\text { I81 }\end{array}$ & $\begin{array}{l}\text { E- } \\
\text { I34 }\end{array}$ & $\mathrm{F}$ & G & I & J1 & J2 & $\mathbb{B}$ & L & $\begin{array}{ll}0 & \mathrm{P}\end{array}$ & $\mathrm{P}, \mathrm{R}$ & $\begin{array}{ll}Q & R\end{array}$ & Rla $\frac{R}{R}$ & \begin{tabular}{c|c} 
Rlb- & R \\
P88 & I
\end{tabular} & $\begin{array}{l}\text { R1b- } \\
\mathbf{I} 269\end{array}$ & $\mathrm{R} 2$ & $\mathrm{~T}$ \\
\hline $\begin{array}{l}\text { tania/Hestern } \\
\text { Sahara }\end{array}$ & 189 & - & 0.53 & 5.29 & 6.88 & - & - & - & - & - & - & - & 55.56 & 11.11 & - & - & - & 13.23 & - & - & & . & - & - & - & 6.880 & 0.53 & - & $\begin{array}{ll}- & - \\
\end{array}$ \\
\hline & 760 & 0.26 & 0.66 & 2.76 & 3.29 & 4.21 & 0.79 & 0.26 & -0 & 0.26 & 1.843 & 3.686 & 67.37 & 0.66 & 0.26 & 0.66 & 0.13 & 6.32 & 1.320 & 0.53 & - & -0 & 0.26 & - & - & 0.923 & 3.55 & - & - \\
\hline & 156 & - & - & 0.64 & 5.13 & 0.64 & 1.92 & 0.64 & -0 & 0.64 & 1.281 & 1.92 & 44.23 & 1.28 & 3.85 & - & - & 21.79 & $\begin{array}{lll}4.49 & 0 .\end{array}$ & 0.64 & 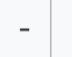 & - & - & 0.640. & \begin{tabular}{l|l}
0.642 &
\end{tabular} & 2.567 & 7.04 & - & - \\
\hline & 601 & - & 0.17 & 0.5 & 0.67 & 1.66 & - & - & - & - & 3 & 3.166 & 62.73 & 1.16 & 2.66 & 0.17 & 0.171 & 16.64 & 2.830 & 0.33 & - & -0 & 0.33 & - & 0.51 & \begin{tabular}{l|l}
1.830 & 0
\end{tabular} & 0.33 & - & 1.16 \\
\hline & 83 & - & - & - & 38.55 & - & - & - & -2 & 2.41 & - & 4.82 & & & - & - & - & - & - & - & - & -2 & 2.41 & - & -6 & 6.02 & - & - & - \\
\hline & 37 & 1.35 & - & 0.54 & 2.43 & 3.24 & 0.81 & 7.03 & 1.620 & 0.819 & 9.192 & 2.431 & 11.89 & 0.76 & 1.08 & 5.68 & 0.542 & 20.81 & 6.750 & 0.270 & 0.810 & 0.270 & 0.540 & 0.272. & 2.162 & 2.972 & 2.97 & 0.54 & 6.22 \\
\hline
\end{tabular}

Feeling tired? Now let us back to China. According to a paper, the $Y$ chromosome haplogroup of DNA from ancient East Asians was examined, in order to genetically link them to modern populations. Fifty-six human remains were sampled from five archaeological sites, primarily along the Yangtze River. The highly ethnic-related $Y$ chromo-some diversity is one of the best materials to describe the relationships (Su et al. 1999; Shi et al. 2005). The $Y$ chromosome haplogroup patterns are quite different among different ethnic groups. In this paper, we present Y SNP data of 48 ancient samples from China, mostly along Yangtze River, to provide a survey on the genetic diversity of the prehistory populations in this region.

The samples collected in this paper were from five sites: Maqiao, Xindili, Wucheng, Daxi, and Taosi. Most of the samples belonged to four different cultures: Daxi C. was the earliest, followed by the Longshan C. 
and Liangzhu C. around the same period, and finally, by Wucheng $C$., the latest in the Shang Dynasty of the Bronze Age. These cultures were most representative for the prehistory of China. Some samples from the same necropolises that belonged to the historical time (later than $841 \mathrm{BC}$ in China) were also collected for comparison. Most of them belonged to the Han Dynasty. The remains of the same culture were sampled from different necropolises, avoiding the bias of relative samples.

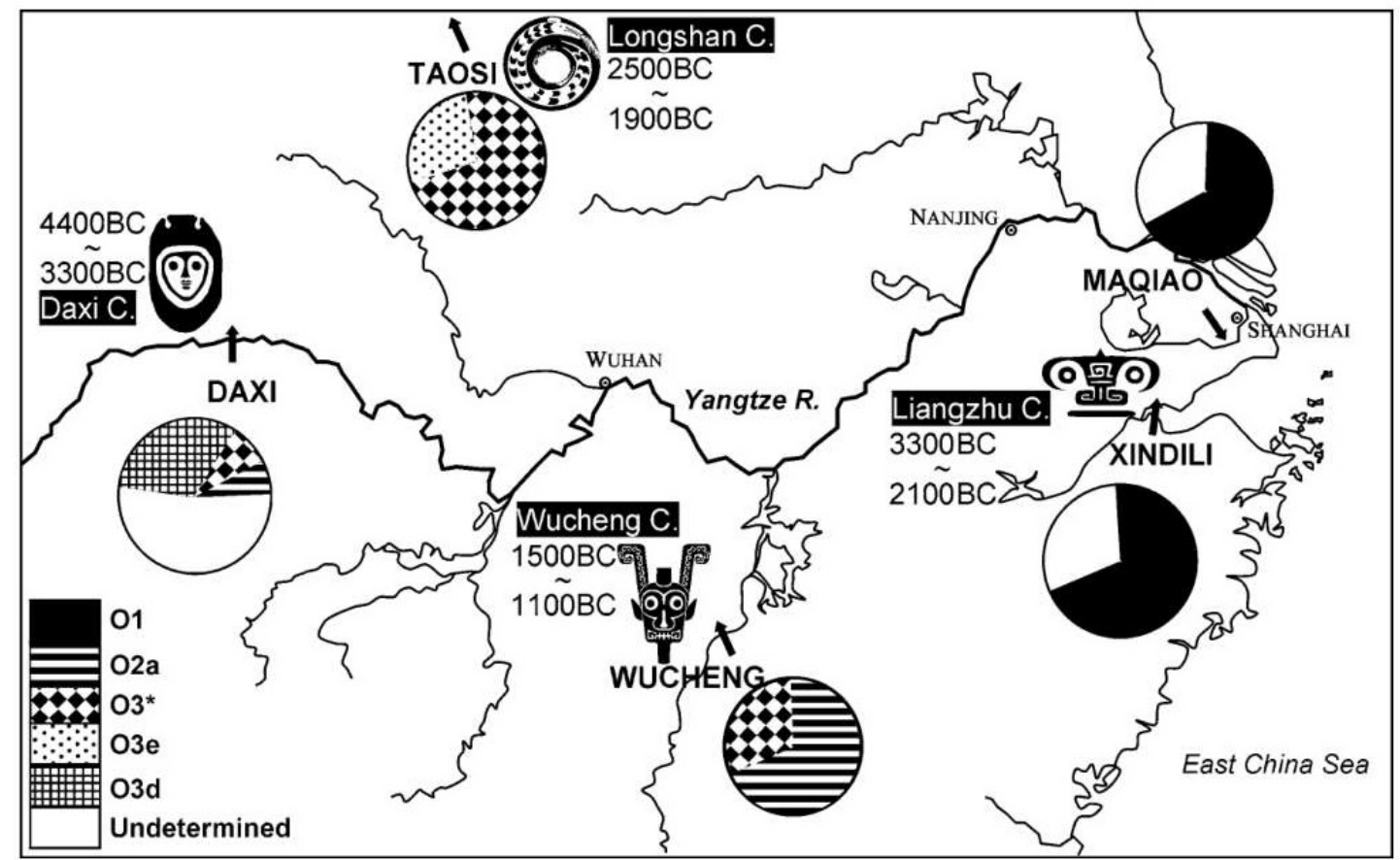

Locations of the archaeological sites, cultures and the distributions of Y SNP haplogroups

For some of the samples, not all of the five SNPs could be amplified, thus haplogroups could not be determined if no mutated alleles were found. However, most individuals were successfully amplified, and the haplogroups were determined for half of them. Therefore, at least $62.5 \%$ of the individual remains ( 30 out of 48 ) belong to $O$ haplogroup, which is 
still the major haplogroup of today's East Asians. These ancient results, consequently, did not differ from the modern populations. The resulting DNA types thus made "phylogenetic sense" (the $Y$ chromosome haplogroup structure), helping to verify the authenticity of the ancient DNA. The previously reported results of ancient $Y$ chromosome were all obtained from samples preserved in cold environments (Keyser-Tracqui et al. 2003; Ricaut et al. 2005; Kuch et al. 2007; Bouakaze et al. 2007).

In two sites of Liangzhu Culture, only $\mathrm{O} 1$ haplogroup were found, and the frequencies of $\mathrm{O} 1$ in two sites were almost the same. That indicated the ancient people of these two sites belonged to the same population. The historical samples from the same sites did not differ from the prehistoric samples in the haplogroup patterns. Even modern populations in this area around Shanghai contain a large proportion of O1 haplogroup (Wen et al. 2004). The consistency of the $Y$ haplogroup pattern in this area, from the Neolithic Age to modern times, reveals that the population might not have been replaced. 01 reaches the highest frequencies in the Taiwan aborigines, and also in Daic speaking populations in the southwest China ( $\mathrm{Li}$ 2005). Therefore, it is also possible that there are some close relationships among Taiwan aborigines, Daic speakers and the ancient Liangzhu Culture populations.

A high frequency of O3d was only found in Daxi Culture. O3d is very rare in modern populations; Hmong-Mien populations have been found 
to contain a small proportion of O3d (Feng 2007). Since O3d occurs at low frequency in the Hmong-Mien, the ancient people of Daxi Culture might be the ancestors of the modern populations of Hmong-Mien. The absence of $\mathrm{O} 3 \mathrm{~d}$ in the historical samples from the Daxi site (it might not have been found because of the small sample size), and the migration of modern Hmong-Mien populations to the southwest might indicate that the prehistoric population in the Three Gorges area has been replaced.

\begin{tabular}{|c|c|c|c|c|c|c|c|c|c|c|c|}
\hline \multirow{2}{*}{$\frac{\text { Site }}{\text { Maqiao }}$} & \multicolumn{2}{|c|}{ Culture } & \multirow{2}{*}{$\frac{\text { Sample size }}{6}$} & \multirow{2}{*}{$\frac{\mathrm{O} 1}{4}$} & \multirow[t]{2}{*}{$\mathrm{O} 2 \mathrm{a}$} & \multirow[t]{2}{*}{ O3* } & $\mathrm{O} 3 \mathrm{~d}$ & $\mathrm{O} 3 \mathrm{e}$ & \multicolumn{2}{|c|}{ Undetermined } & Missing \\
\hline & $\mathrm{Lia}$ & zhu & & & & & & & 2 & & \\
\hline & His & ical & 3 & 2 & & & & & 1 & & \\
\hline \multirow[t]{2}{*}{ Xindili } & \multicolumn{2}{|c|}{ Liangzhu } & 9 & 5 & & & & & 3 & & 1 \\
\hline & \multicolumn{2}{|c|}{ Historical } & 4 & 3 & & & & & & & 1 \\
\hline Wucheng & \multicolumn{2}{|c|}{ Wucheng } & 4 & & 2 & 1 & & & & & 1 \\
\hline \multirow[t]{2}{*}{ Daxi } & \multicolumn{2}{|c|}{ Daxi } & 20 & & 1 & 1 & \multicolumn{2}{|l|}{5} & 9 & & \multirow[t]{2}{*}{4} \\
\hline & \multirow{2}{*}{\multicolumn{2}{|c|}{ Longshan }} & 5 & & & 2 & & & 3 & & \\
\hline Taosi & & & 5 & & & 3 & \multicolumn{2}{|r|}{1} & & & 1 \\
\hline \multicolumn{12}{|c|}{ Frequencies in modern populations (\%) } \\
\hline Family & \multicolumn{3}{|c|}{ Reference } & \multicolumn{2}{|c|}{ Sample size } & $\mathrm{O} 1$ & \multicolumn{2}{|c|}{$\mathrm{O} 2 \mathrm{a}$} & O3* & O3d & $\mathrm{O} 3 \mathrm{e}$ \\
\hline \multicolumn{2}{|l|}{ Daic } & \multicolumn{2}{|c|}{$\mathrm{Li}(2005)$} & \multicolumn{2}{|l|}{1,465} & 34.87 & \multicolumn{2}{|c|}{26.52} & 10.05 & 0.19 & 9.36 \\
\hline \multicolumn{2}{|c|}{ Austronesian } & \multicolumn{2}{|c|}{$\mathrm{Li}(2005)$} & \multicolumn{2}{|l|}{381} & 24.07 & \multicolumn{2}{|c|}{16.25} & 22.41 & 2.01 & 2.32 \\
\hline \multicolumn{2}{|c|}{ Sino-Tibetan } & \multicolumn{2}{|c|}{ Su et al. (1999) } & 281 & & 1.57 & 8. & & 17.24 & 0.53 & 32.74 \\
\hline Hmong-M & & Fen & (2007) & 934 & & 8.49 & & 87 & 17.19 & 10.45 & 26.38 \\
\hline Austro-Asi & & $\mathrm{Li}($ & 005) & 140 & & 1.79 & & 40 & 18.49 & 6.25 & 19.73 \\
\hline Altaic & & Suc & al. (1999) & 303 & & 1.74 & & & 4.11 & & 6.60 \\
\hline
\end{tabular}

Case counts of Y SNP haplogroups of the archaeological sites

Among three sites-Wucheng, Daxi and Taosi-O3* and O2a were shared. And $\mathrm{O}^{*}$ is most common in modern East Asians, and $\mathrm{O} 2 \mathrm{a}$ can been found in different populations in southwestern China. Besides, there were still some genetic differences between the populations in the areas of Yangtze River and the Yellow River, as O2a was not found from 
the Taosi site.

O1 was not found out of Liangzhu Culture, bringing a noticeable genetic difference between coastal and inland populations, which can still be observed in modern populations. $\mathrm{O} 1$ distributes along the coast of East Asia, from Manchuria in the north to Malaysia and Indonesia in the south (Su et al. 1999; Li 2005; Zhang et al. 2007). This distribution may indicate that there were at least two different migration routes for the early peopling of East Asia. Hardly any genetic flows could be observed between the coastal route and the inland route in the prehistoric peoples. So in my point of view, this may demonstrate that hyperdiffusionism from Egypt by Grafton Elliot Smith.

Now why is human Y-chromosome DNA haplogroups $\mathrm{O}$ be found in Egypt, but no in the image above? I speculate that there must be a "indigenous people" in the Liangzhu area to return to Egypt with the fleet. This phenomenon was very common in the history of Egypt. The ancient Egyptian fleet often brought back some animals and plant species, including ethnic groups, back to Egypt from other places. During the eighteenth dynasty of Egypt, when Thutmose III conquered a place in the West Asia region, he took the nobles and princes of this place back to Egypt and educated them in Egypt.

Now let us back to Wuxi, China (无锡). Taibo (泰伯 ) or Wu Taibo was the eldest son of King Tai of Zhou and the legendary founder of the State 
of Wu. According to Sima Qian, Taibo was the founder of the State of Wu(吴国).

Born into the Jĩ clan (姬) of predynastic Zhou, Taibo was the eldest son of King Tai of Zhou. He had two younger brothers, Zhongyong and Jili. The King of Zhou wished to make his youngest son Jili to inherit the reins of power, so Taibo and Zhongyong traveled southeast and settled in Meili

（梅里） in present-day Jiangsu province. There, Taibo and his followers set up the State of $\mathrm{Wu}$, and made Meili its capital. Taibo's grand nephew, King Wu of Zhou overthrew the Shang Dynasty and started the Zhou Dynasty.

During his reign, Taibo developed irrigation, encouraged agriculture, and dug the Canal Du. When Taibo died, he had no heir and passed the throne to his younger brother Zhongyong. Taibo's tomb was set up in today's Hongshan Town, Wuxi (无锡鸿山). 


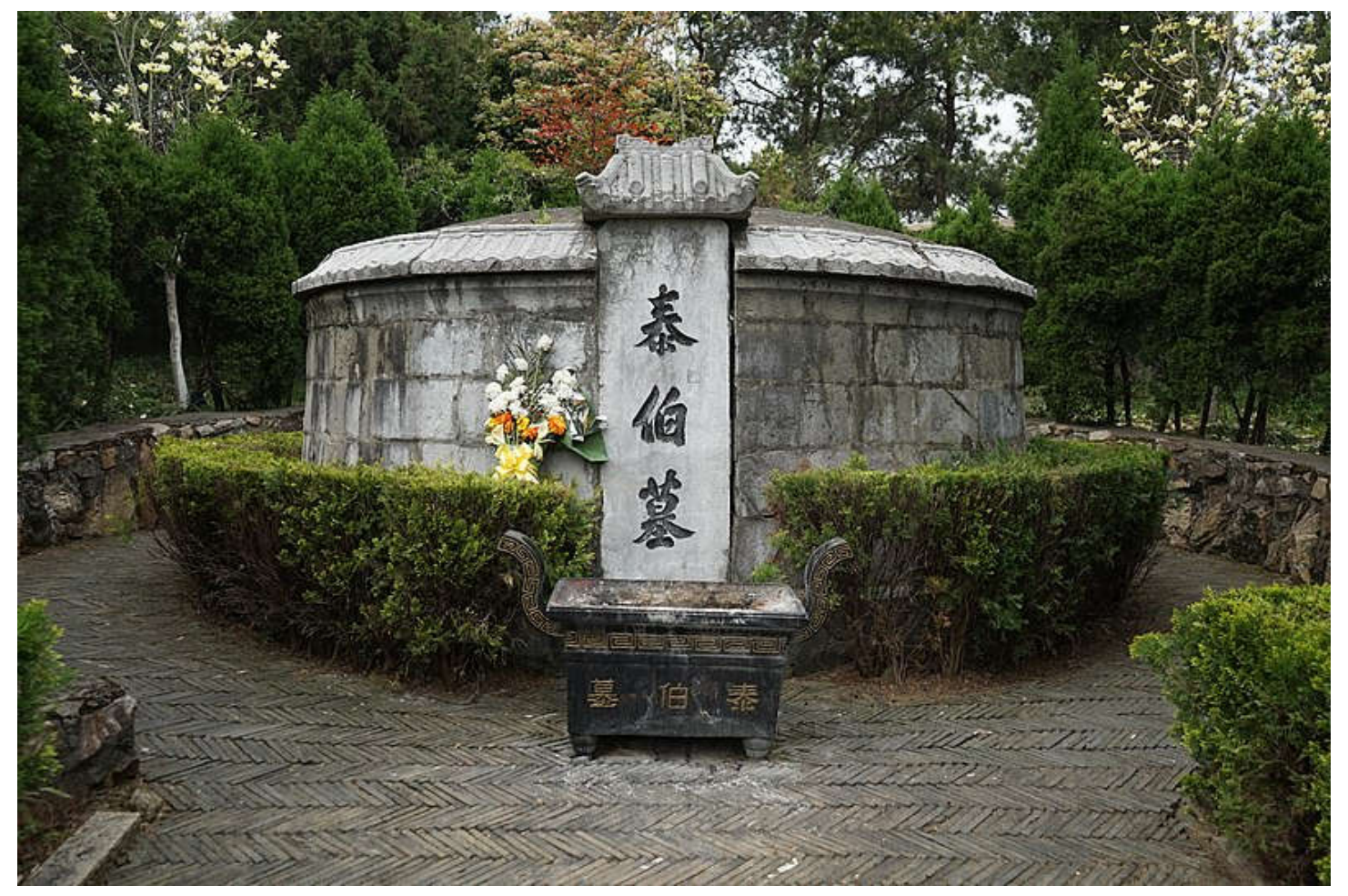

Taibo's tomb

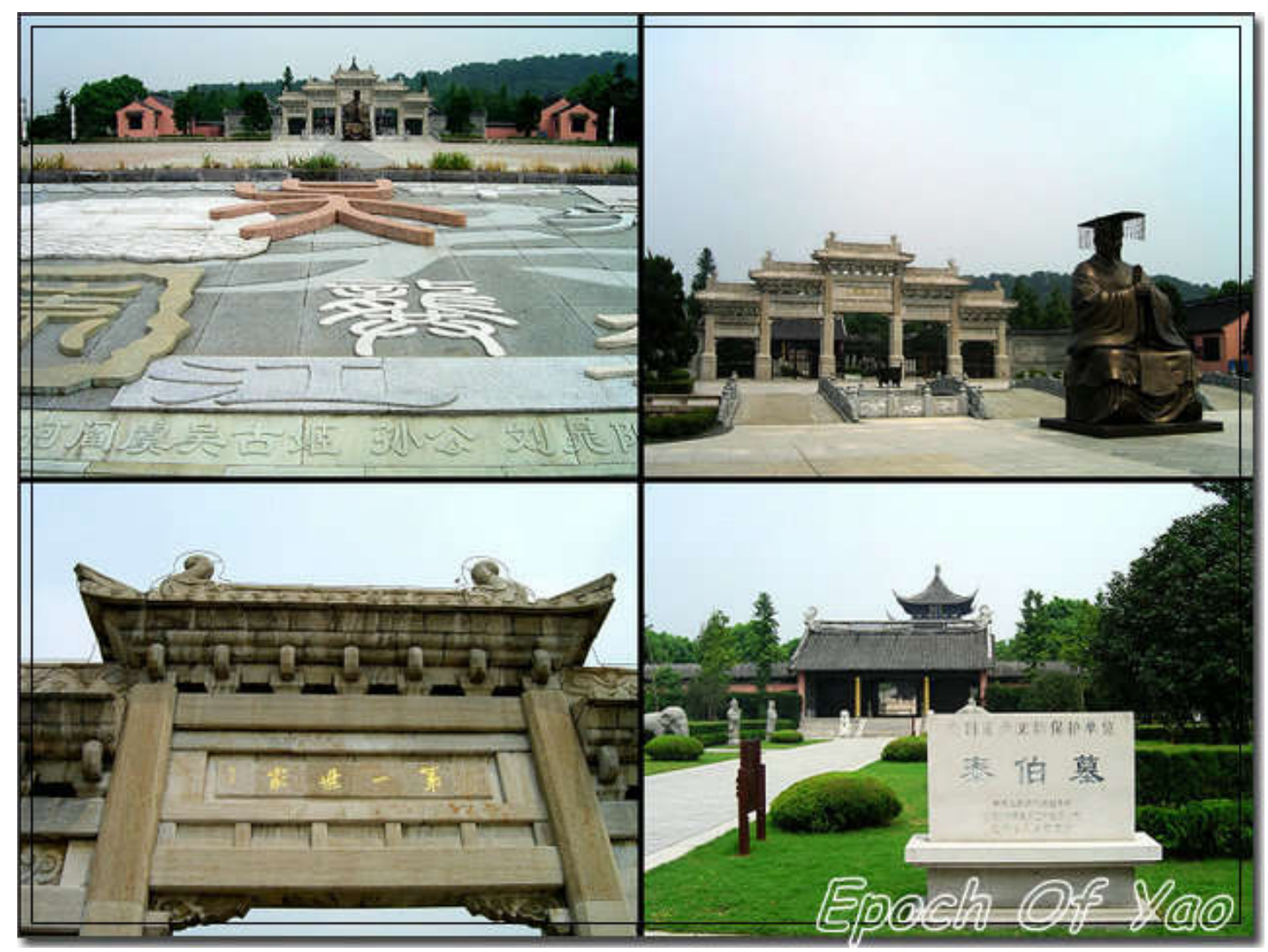

Taibo's tomb

And the statue below was unearthed in Taibo's tomb: 


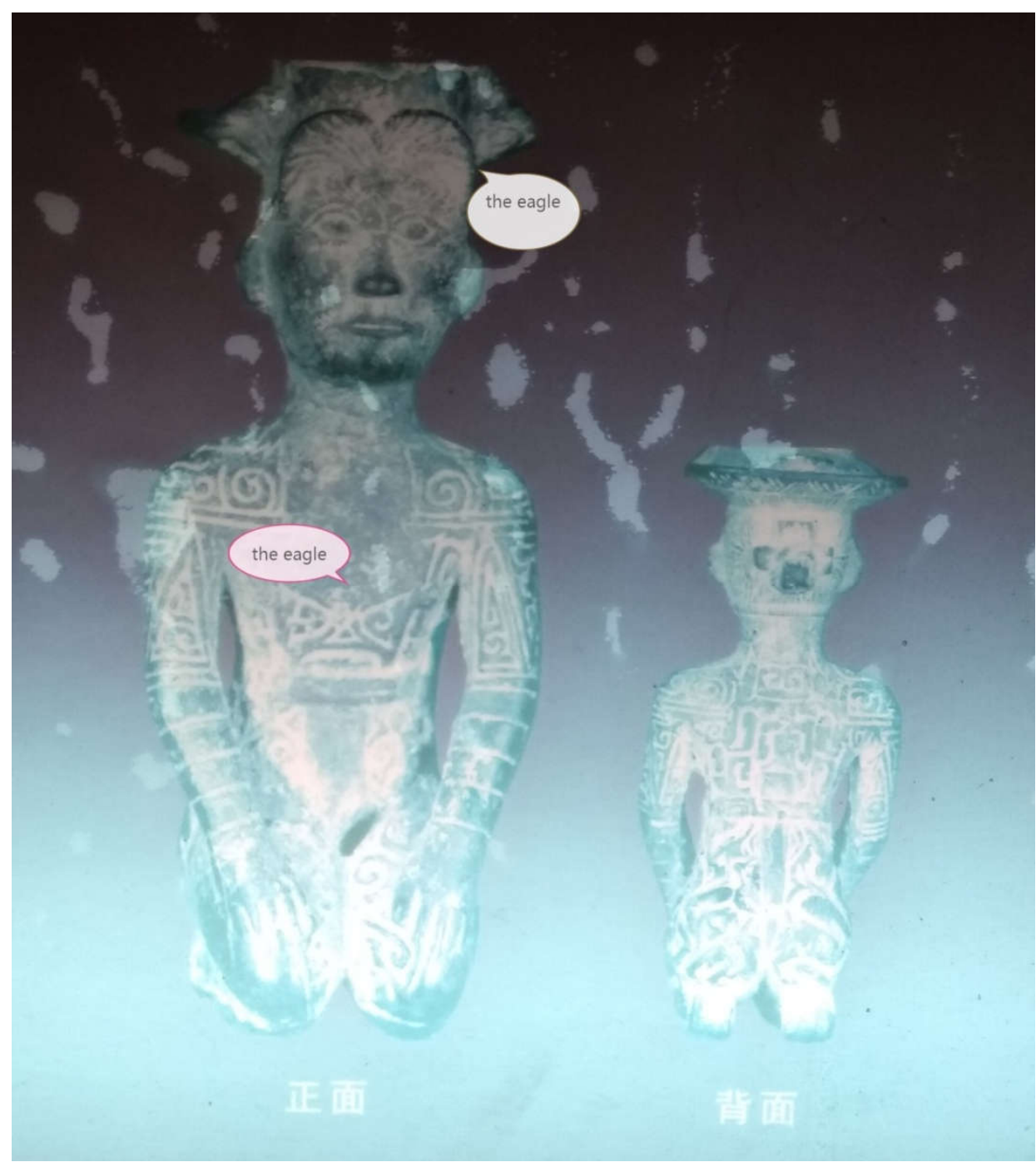

The statue unearthed in Taibo's tomb

The statue below was a man from "Baiyue" (百越). Also had a eagle in the front: 


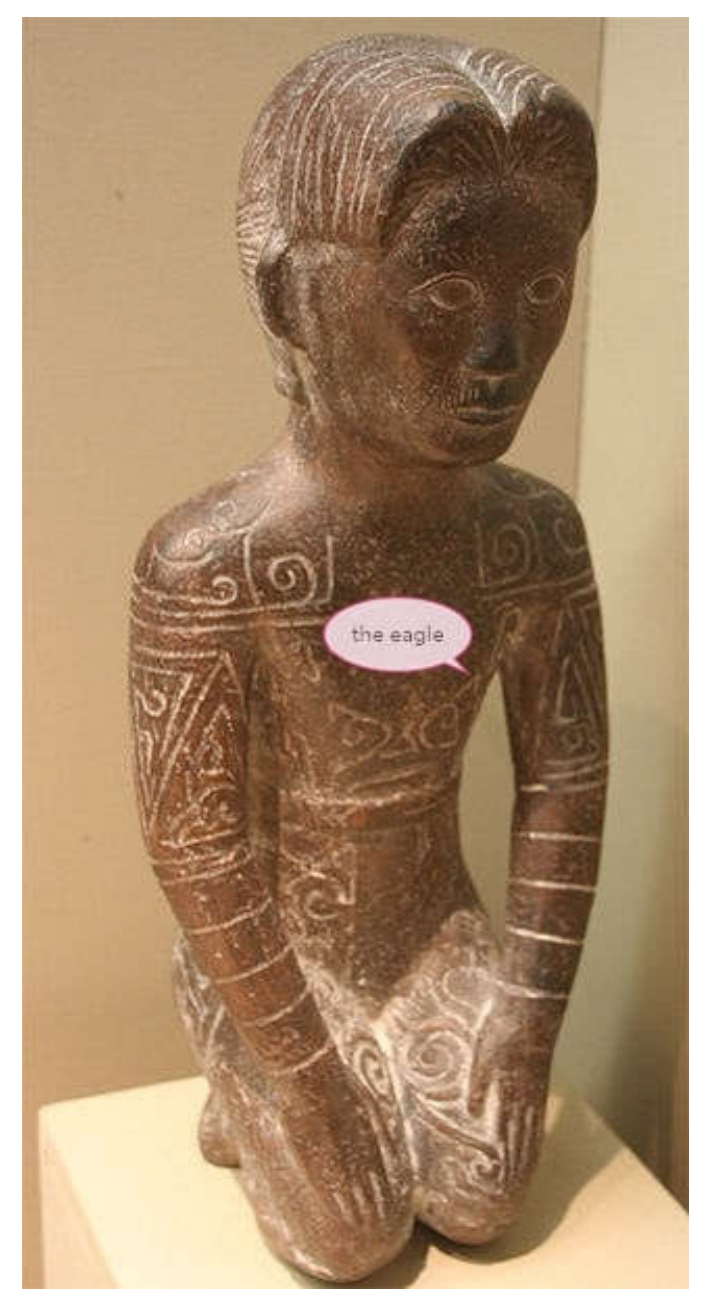

An statue of a man, dating from State of Yue, located in the State Museum of Zhejiang province, Hangzhou, Zhejiang, China.

And Horus is one of the most significant ancient Egyptian deities. He was worshipped from at least the late prehistoric Egypt until the Ptolemaic Kingdom and Roman Egypt. He was most often depicted as a falcon, most likely a lanner falcon or peregrine falcon, or as a man with a falcon head. Horus is recorded in Egyptian hieroglyphs as ḥr.w "Falcon"; the pronunciation has been reconstructed as ha:ruw. Additional meanings are thought to have been "the distant one" or "one who is above, over". 


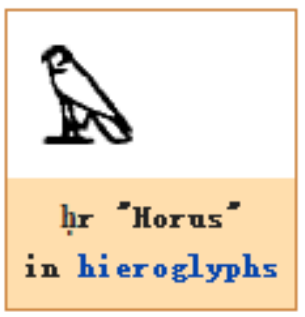

Horus may be shown as a falcon on the Narmer Palette, dating from about the 31st century BC.

The image below is Horus, Louvre, Shen rings in his grasp:

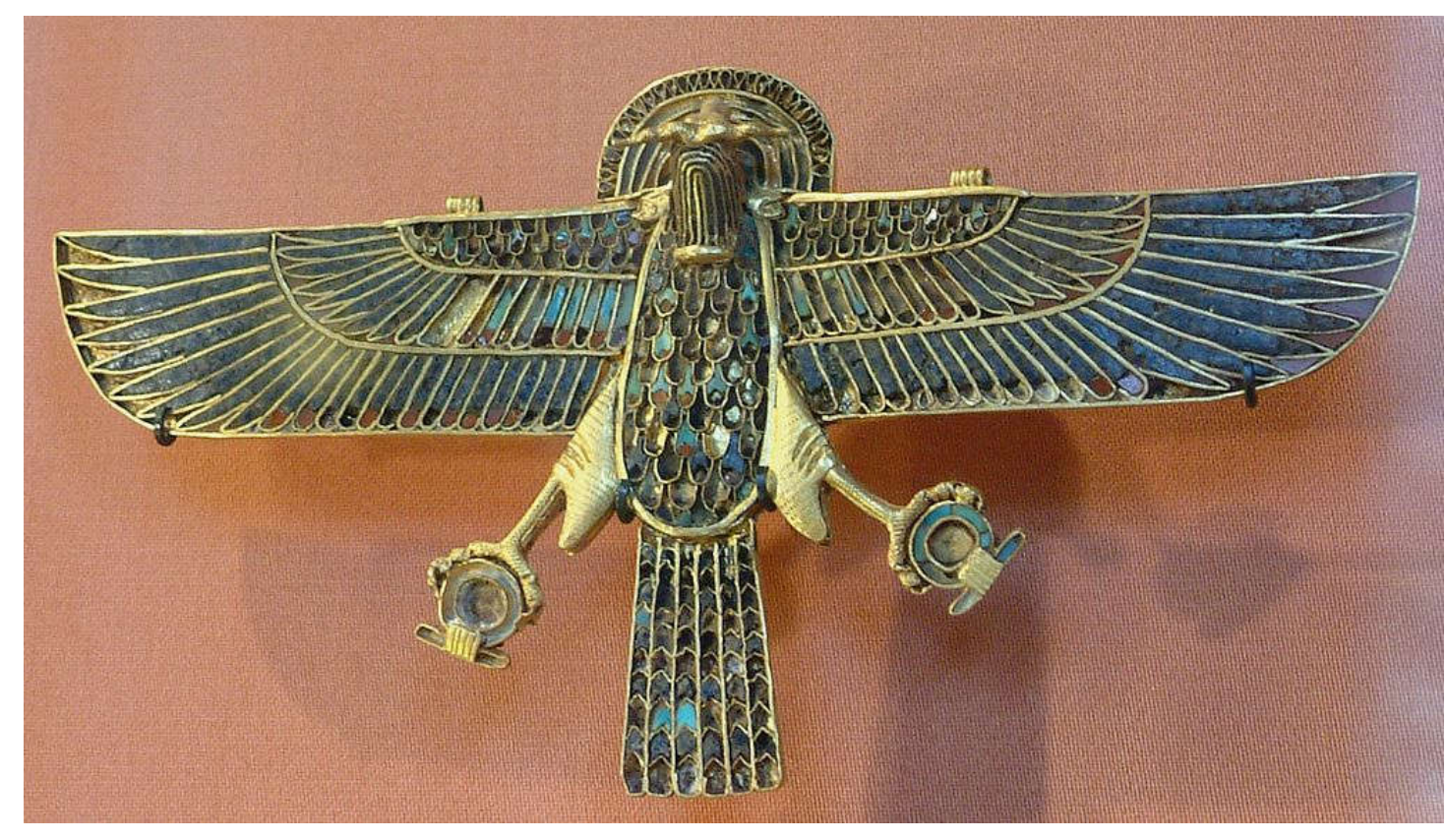

Amulet representing a ram-headed falcon. Ancient Egypt, 1254 BC (26th year of the reign of Ramses II, XIXth Egyptian dynasty), found on the mummy of an Apis bull in the Serapaeum of Memphis at Saqqara. Gold, lapis, turquoise and cornelian.

The statue below is God Horus as a falcon: 


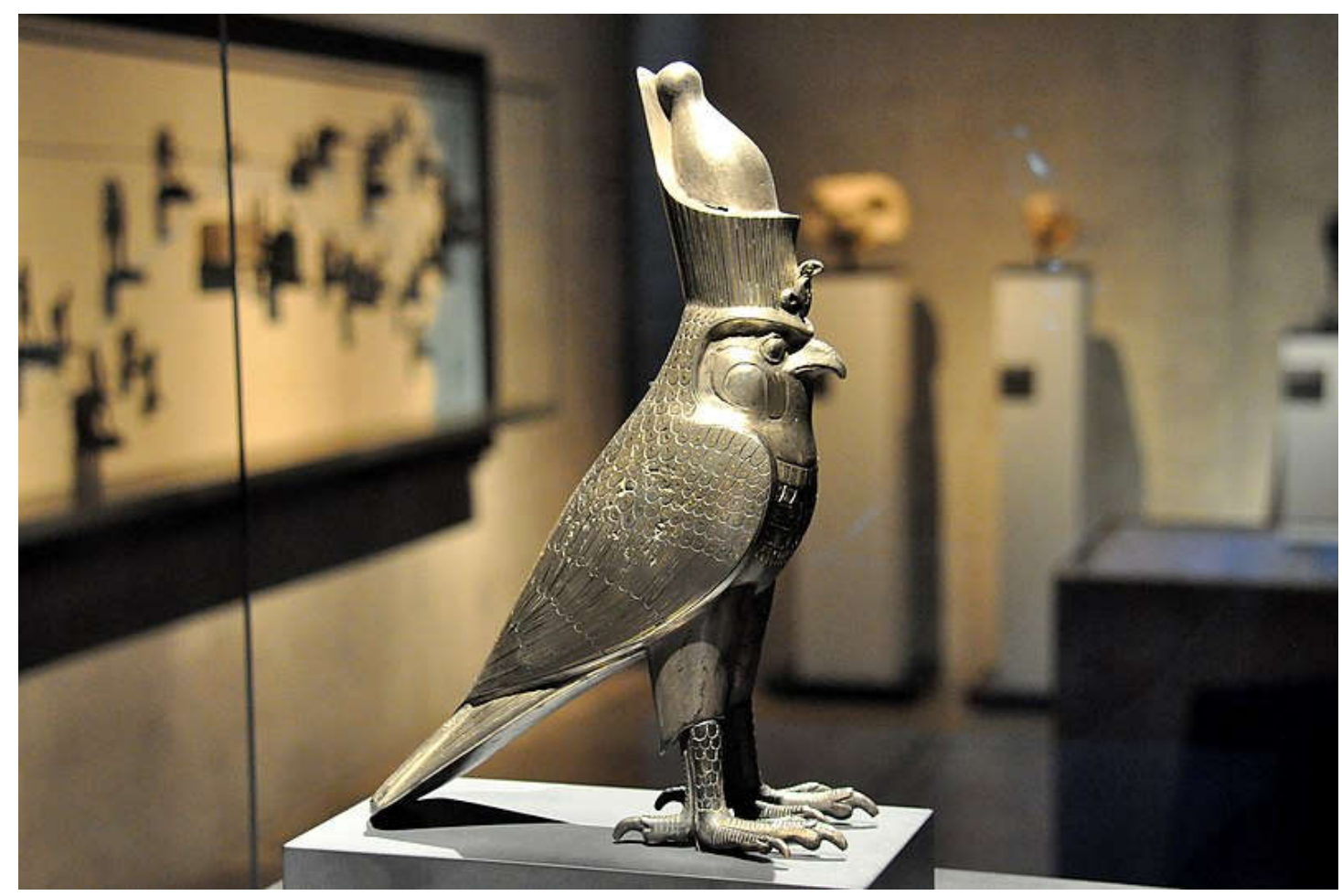

God Horus as a falcon wearing the Double Crown of Egypt. 27th dynasty. State Museum of Egyptian Art, Munich

So from the above, I speculate that the eagle in the statue unearthed in Taibo's tomb and the eagle in a statue of a man, dating from the State of Yue era, the eagles in the two statues resemble the God Horus in Egypt. I can also get a conclusion that Wuxi (无锡) and Zhejiang(浙江) was once Egypt's colony.

Now let us back to Wuxi (无锡)，China. In the south of Mount Hui (惠 山), there is a small hill called Zhangshan Hill(嶂山). Its former name was 璋山. So what does 璋(Zhang)mean ? It means jade plaything or jade ornament. In the images below, are opening of the mouth's ritual sets, they resemble Chinese character 璋. 


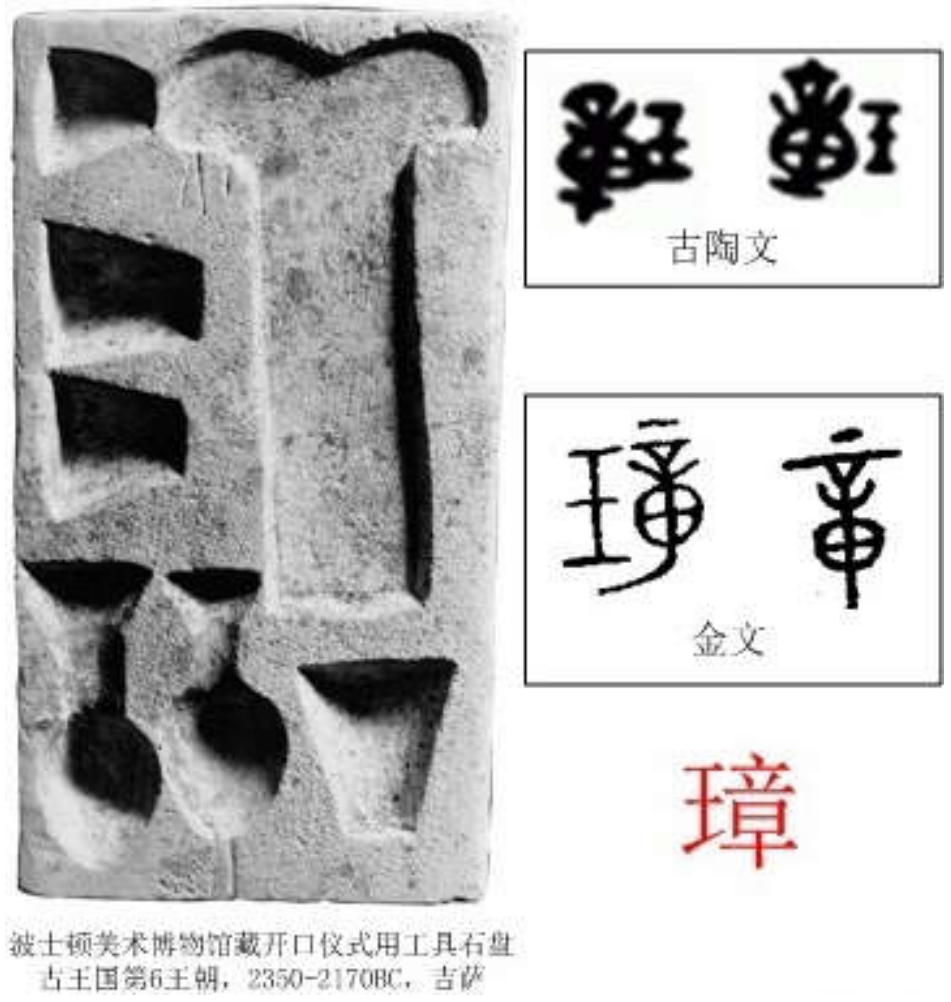

Opening of the Mouth kit ,Museum of Fine Arts, Boston

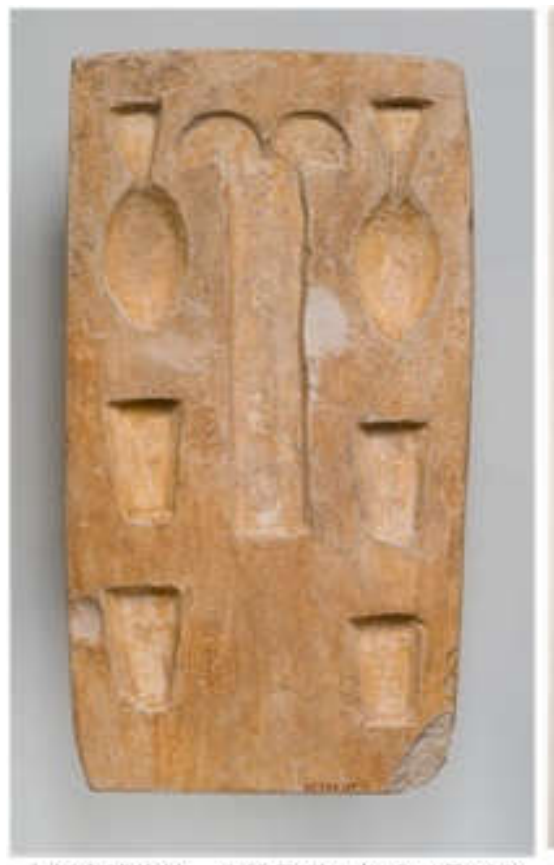

大都会溥物馆，古埃及开口伩式工具石盤 古王团 5-6王朝

$2465-2150 B C$

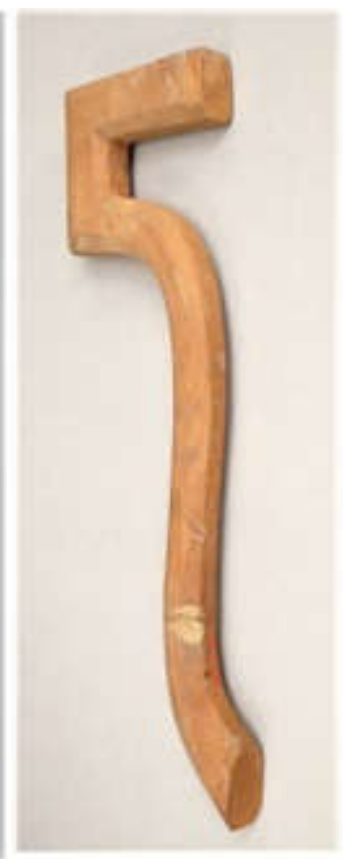

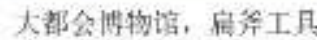
新王国第18主蚂

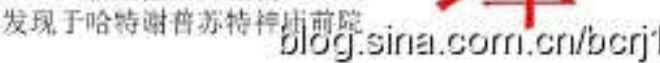
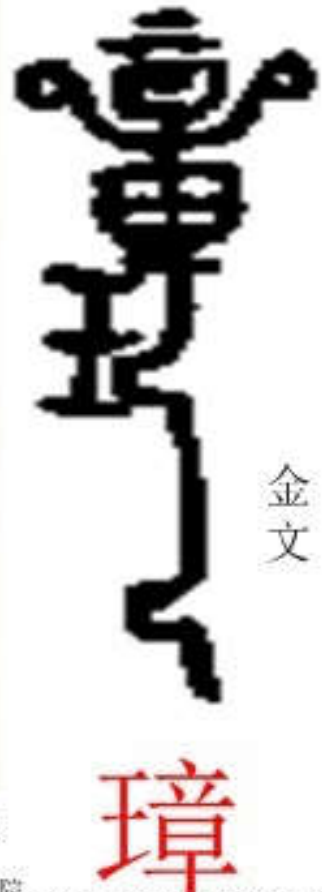

art, New York

This is the photo of Zhangshan Hill (嶂山), from the front: 


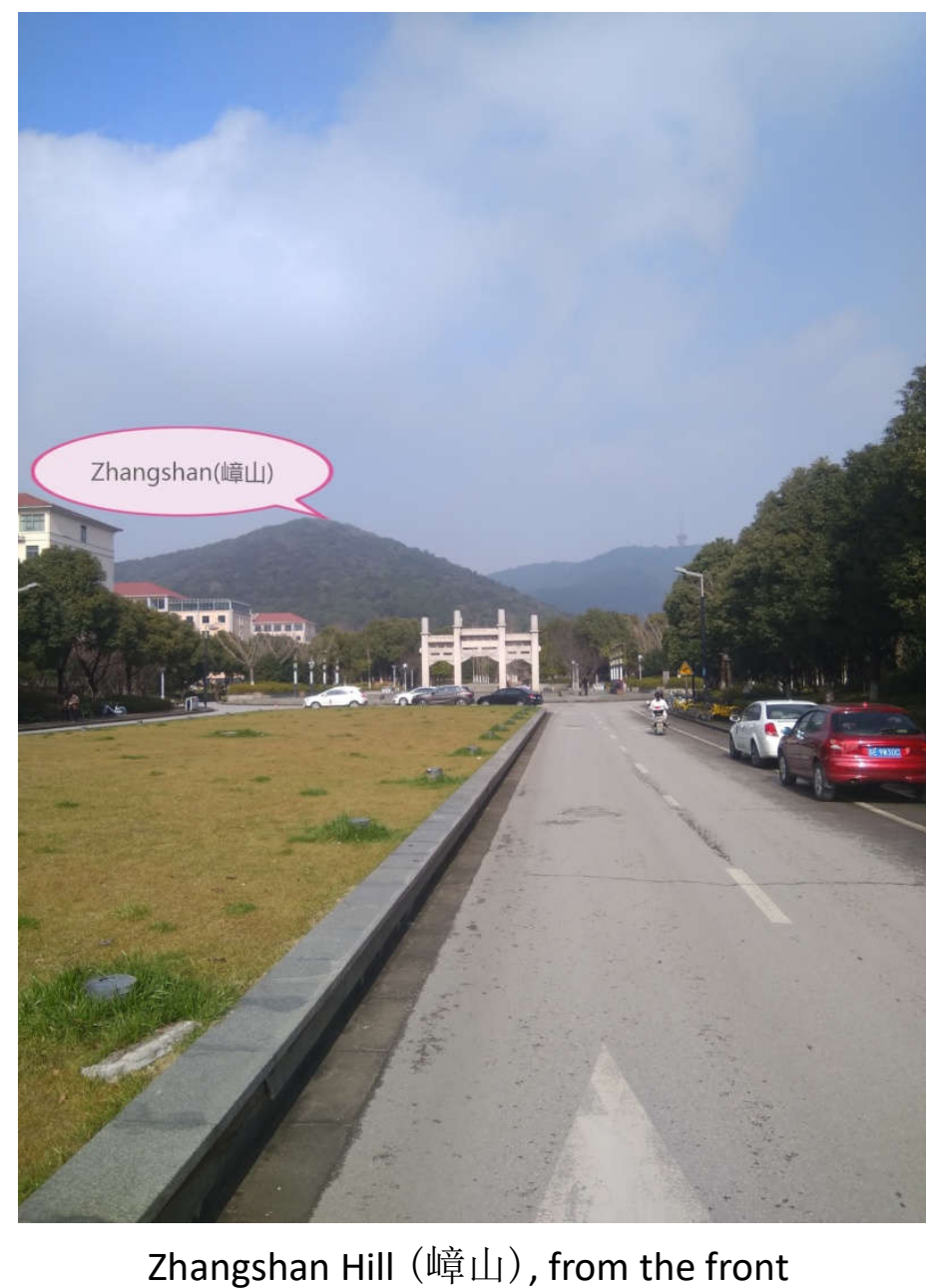

This is the overlooking photo of Zhangshan Hill (嶂山), it looks like a pyramid. 


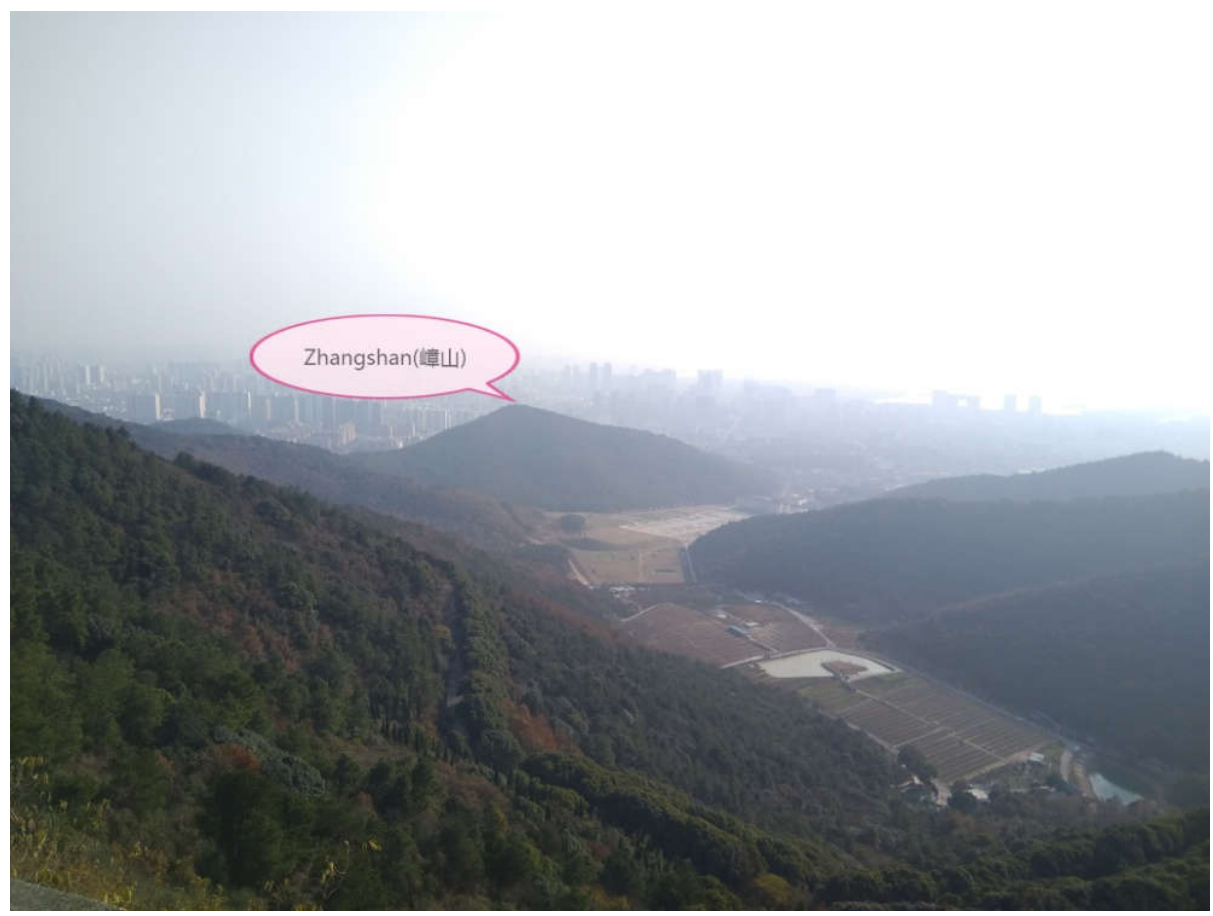

A overlooking photo of Zhangshan Hill (嶂山)

So from the above, I get a conclusion that Zhangshan Hill (嶂

山) means Egypt governor or pharaoh had come to Wuxi.

In the south of Mount Hui, and the east of Zhangshan Hill(嶂山)， there is a small hill called Chanshan Hill (产山). The image below is Chinese character 产:

\section{E Oracle characters 甲骨文 (0)}

There is no known oracle characters found. 没有已知的甲骨文.

回 Bronze characters 金文 (4)
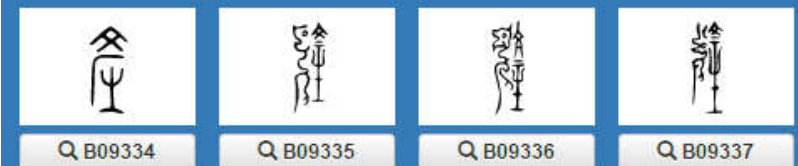

7 Seal characters 说文解字的管字 (1)

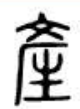

Q $\$ 04453$ 


\section{Chinese character 产}

There is a folk proverb in Wuxi, which is called "Chanshan Hill (产 山) emerged overnight". Exaggerated as it is, but it indicates that Chanshan Hill emerged rapidly. Since no big earthquakes happened in Wuxi (无锡), so I get a hypothesis that Chanshan Hill is a man -made hill. In the south of Chanshan Hill(产山), there is a spot called Heliekou (河埒口), and what does 埒 (Lie) mean? It means enclosure, dike, embankment. So Heliekou(河埒口) means enclosure near the Liangxi River（梁溪河）.The image below is Chinese character 埒:

\section{$\square$ Seal characters 说文解字的筦字 (1)}

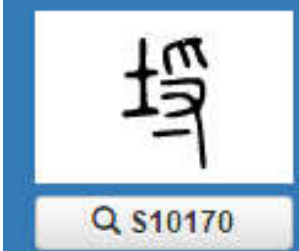

Chinese character 埒

The following image is Chanshan Hill (产山). 


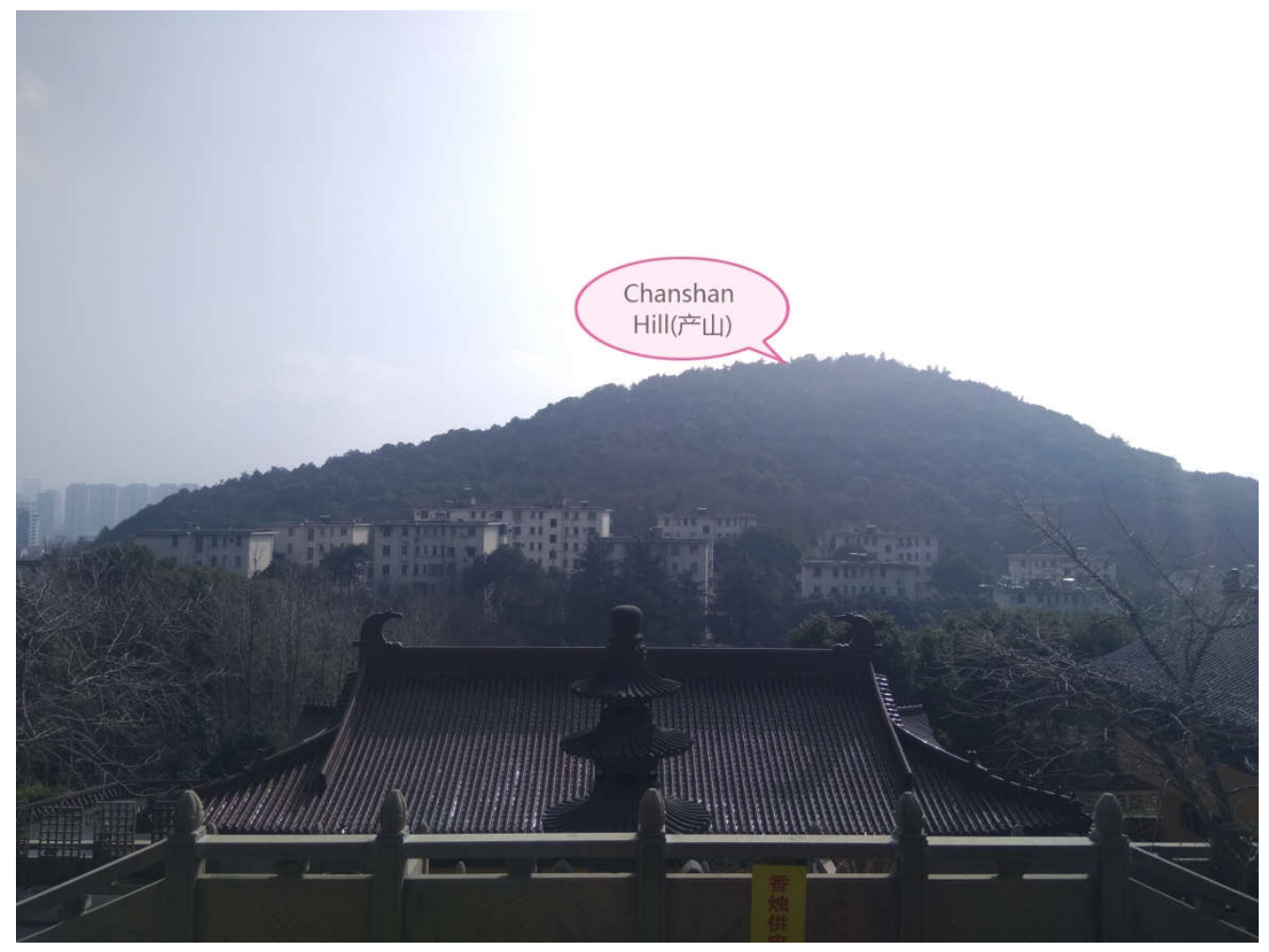

A overlooking photo of Chanshan Hill (产山)

The photo below is Chanshan Hill (产山) and Zhangshan Hill (嶂山)， the left is Chanshan Hill, and the right is Zhangshan Hill.

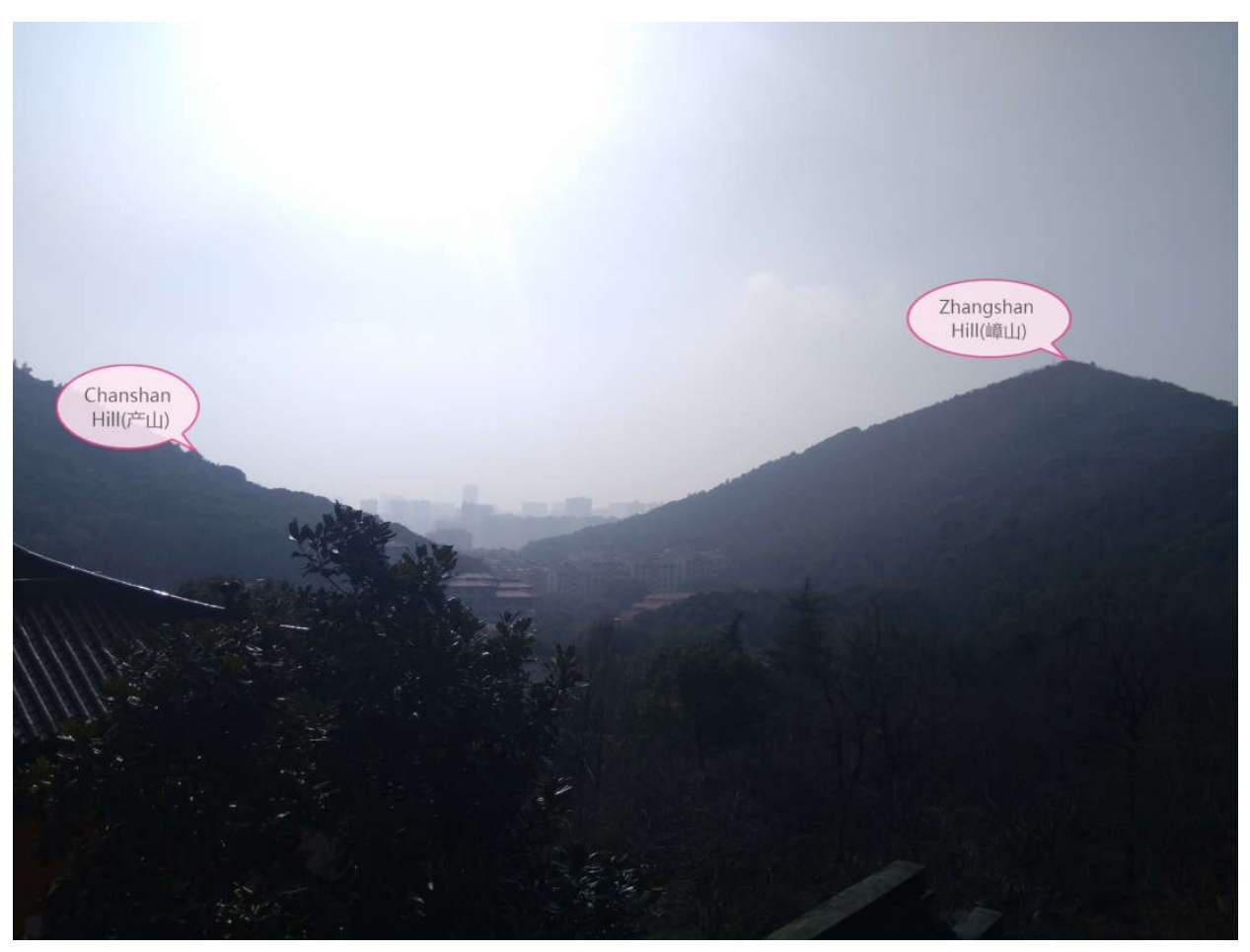

Chanshan Hill and Zhangshan Hill

So from the above, we can get a conclusion that Chanshan Hill (产 
山) is a man-made pyramid, and Heliekou(河埒口) means enclosure around the man-made pyramid- Chanshan Hill, this pyramid complex looks like Djoser's Pyramid Complex which has enclosure around it.

Now let us back to Mount Xi，Wuxi (无锡锡山). As the city Wuxi (无 锡) is named for the hill, and local legend purports that Xishan （锡山） was once visited by the emperor Shi Huangdi(秦始皇) (Leffman, David. China, p. 435. In the south of Mount Xi（锡山）, there are Liangzhu (良渚) ruins. There are three sites that are divided into blocks by the moat and joined together into a large block of about 20,000 square meters. There are four large mounds, of which the east and west dug up the Liangzhu tombs and their homes fifty years ago. It is not excluded that there is a high altar and the presence of paddy fields. It has been proved that the Majiabang-Songze-Liangzhu-Wuyue-Han-level cultural accumulation. This should be a large settlement ruin that spans 5,000 years. The image below is the ruins of Mount Xi, the red circle means Wuyue culture, the blue circle means Neolithic culture, the two together means culture accumulation. 


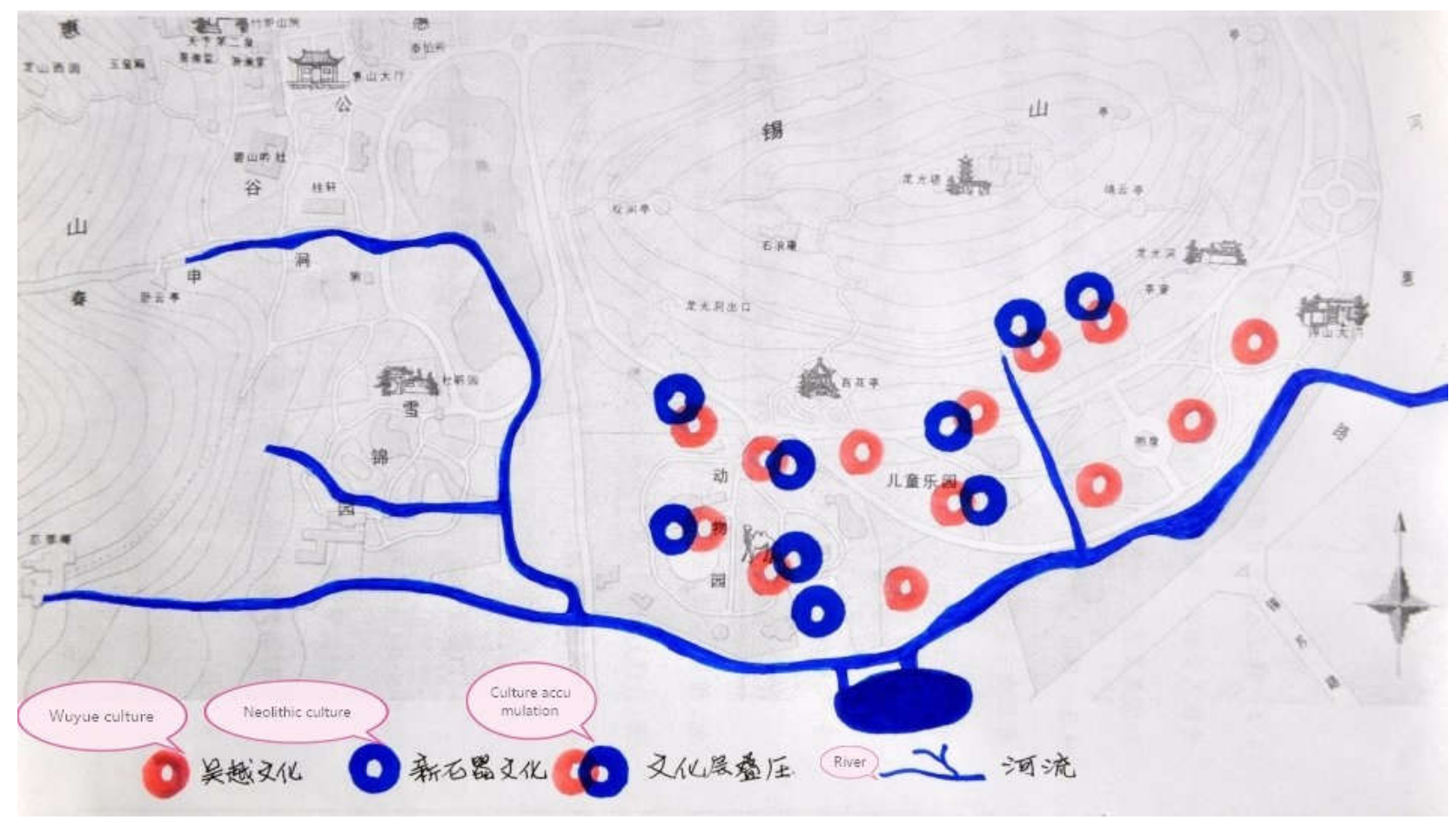

The ruins of Mount Xi (锡山)

Mount Xi is also known as Xishen Mountain (lit. "Western God Mountain") and Wushan Mountain (lit. "Wizard Mountain"). The ancient Baiyue (百越) people sacrificed ox to worship God, and Mount Xi （锡山）was the sacred mountain of the wizard who buried there. In the ancient times, it was a holy space of Baiyue people. This phenomenon was similar to the adoration of the golden calf in Egypt. Besides, magic was popular in ancient Egypt, it is similar to Baiyue (百越) people who once lived in Mount Xi（锡山). And the following picture is Mount Xi（锡 山) : 


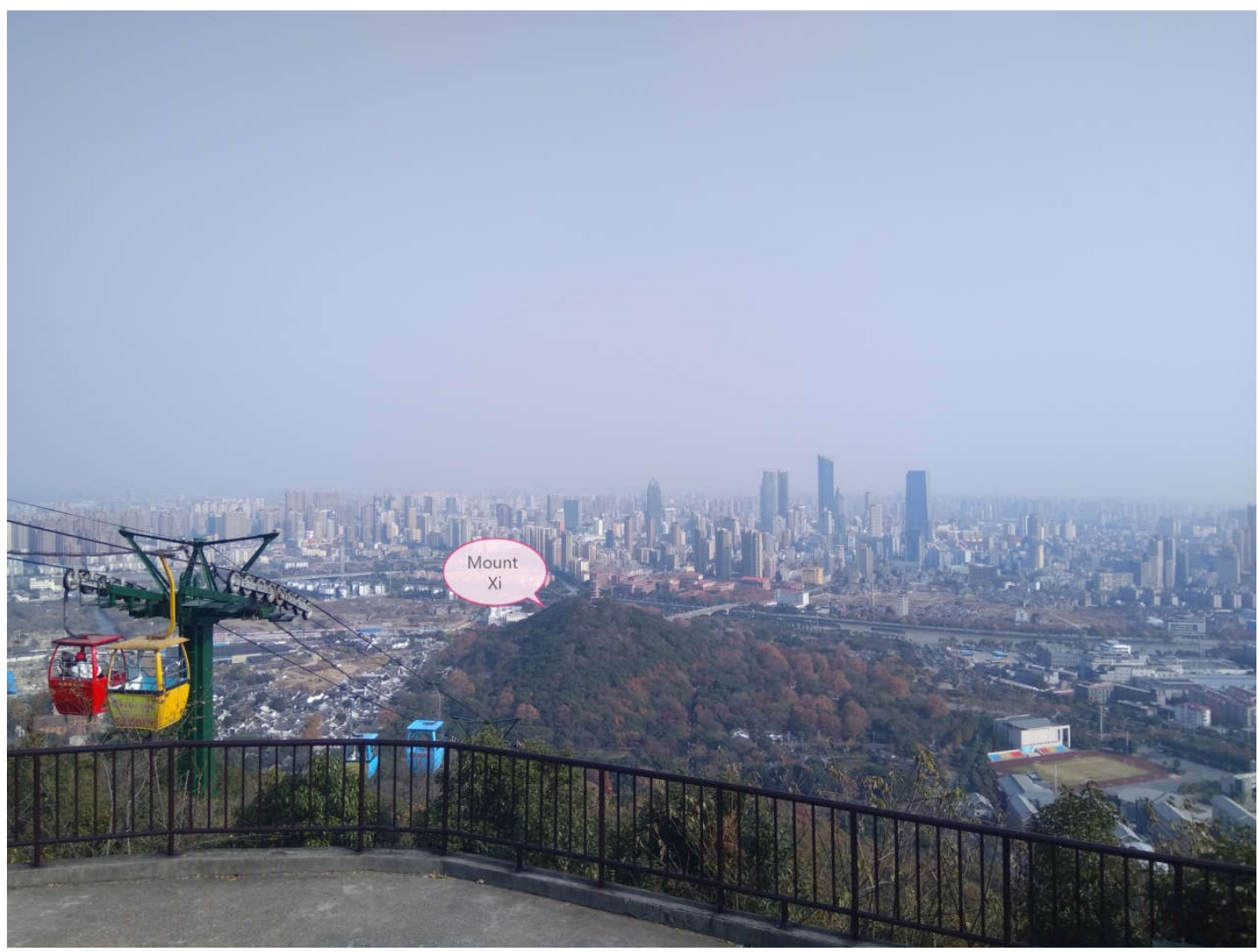

Mount Xi（锡山）

The photo below is Mount Xi (锡山) and Mount Hui (惠山). The small is Mount Xi（锡山）,the large is Mount Hui (惠山). From the photo below, we can also see Mount Xi（锡山）looks like a pyramid.

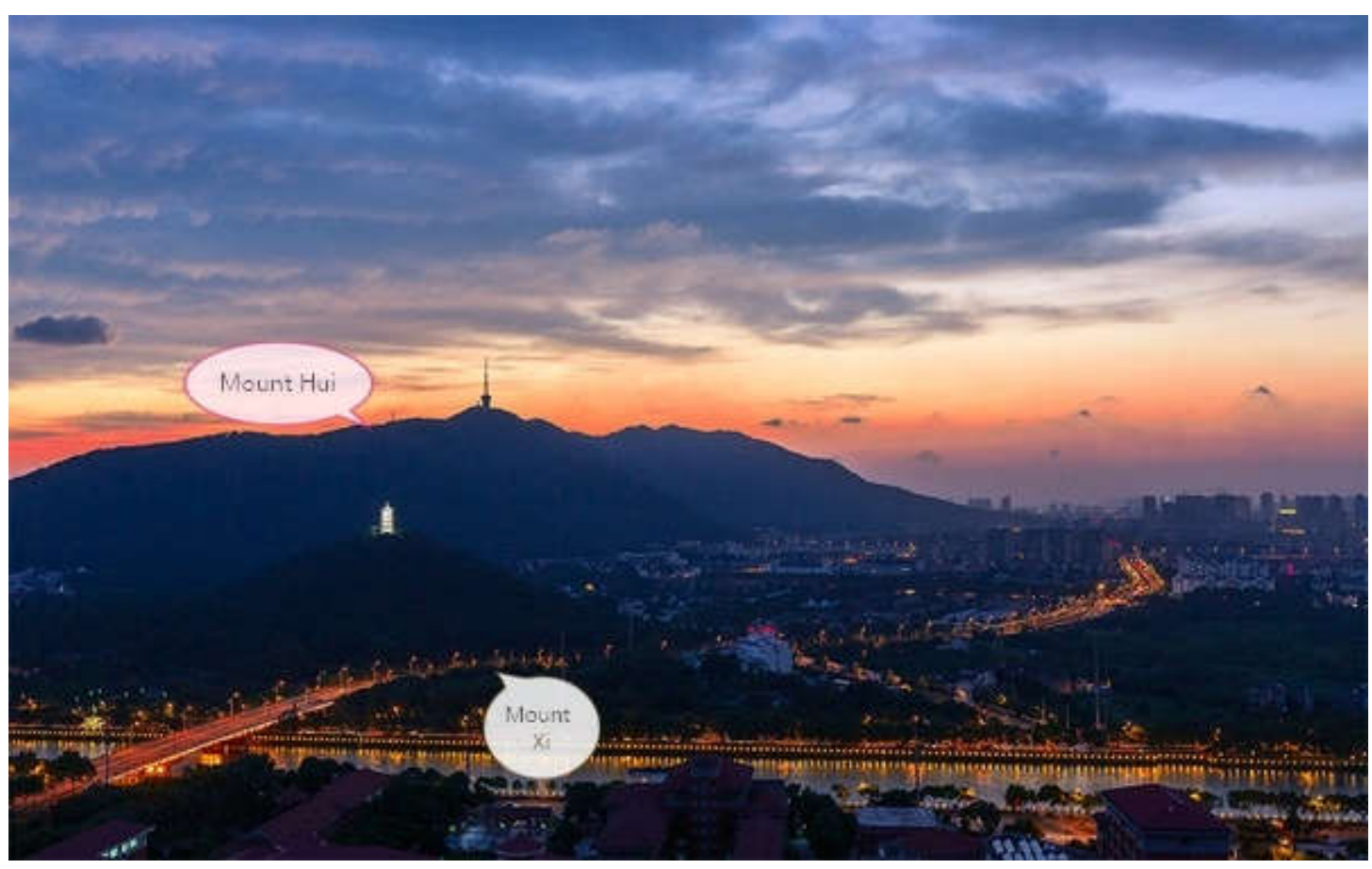


Now let us see Wuxi Huishan clay figurines. Huishan clay figurines（惠 山泥人） are Wuxi（无锡）'s most famous folk craft. The techniques for making and decorating the figurines developed among the ordinary people of the area of many centuries, and these traditional styles and techniques are still used today. The themes and decoration of the small statues make them a charming example of traditional Chinese folk culture. It is said that Huishan clay figurines have a history of over 1,000 years, originating in the Northern and Southern Dynasties Period (386-581).

The main styles of traditional figurines are animals and chubby babies. The most common figurines are of chubby babies, with outsized heads and wide smiles, sitting crossed legged. The baby figurines were always depicted rather pudgy, with rosy cheeks and bright eyes to show their good health. The babies are always shown holding plants, animals, or household objects with allegorical meanings promising health, wealth, or happiness. And they are often based on nearly untranslatable Chinese language puns and homophones. The classic chubby baby figure is the Da Ah Fu（大阿福）, which has become something of a symbol for Wuxi itself. The Da Ah Fu figurine is always shown with five allegorical symbols, representing a range of wishes. In its hair it wears a peony flower, a symbol of status and prosperity. Its clothes are decorated in five colors to represent wealth, and hanging from its neck is a lock which represents 
long life. The Da Ah Fu's toy green maned lion(I think the lion resembles Egyptian goddness Tefnut in meaning and shape.) is a also charm to ward off evil spirits. The symbolism extends to the tips of its toes - it wears white soled shoes representing success in the imperial examinations.

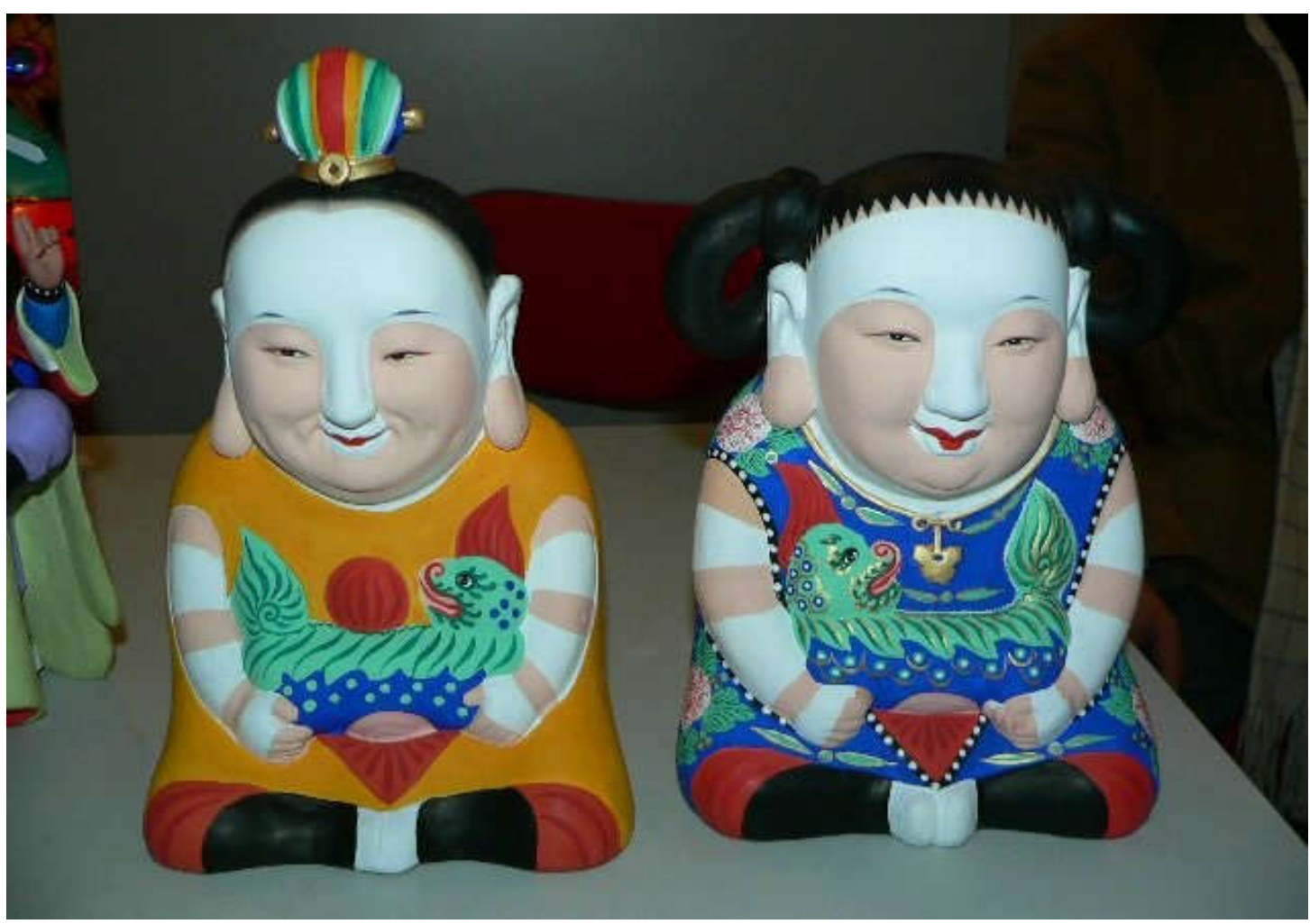

Da Ah Fu（大阿福）figurine, Qing Style

Cats are perhaps the most classic type of animal figurines. Hardly cute kittens, they are crafted to look almost fierce, traditionally with long droopy whiskers made of silk. Their popularity and somewhat imposing demeanor stem from the importance of silk in rural Jiangsu. The silk worms are an easy snack for mice as they spin the cocoons that are later used to make silk. Peasants traditional kept cats to scare away, or better yet, eat the pesky mice. The cat figurines were both a good luck charm against mice, and also a reminder of the prosperity that came from a 
successful silk harvest. The two other traditional animals, the "spring ox" and a large rooster, also reflect China's peasant traditions. So in my point of view, I think the cat figurines resemble Egyptian goddess Bastet in meaning and shape.

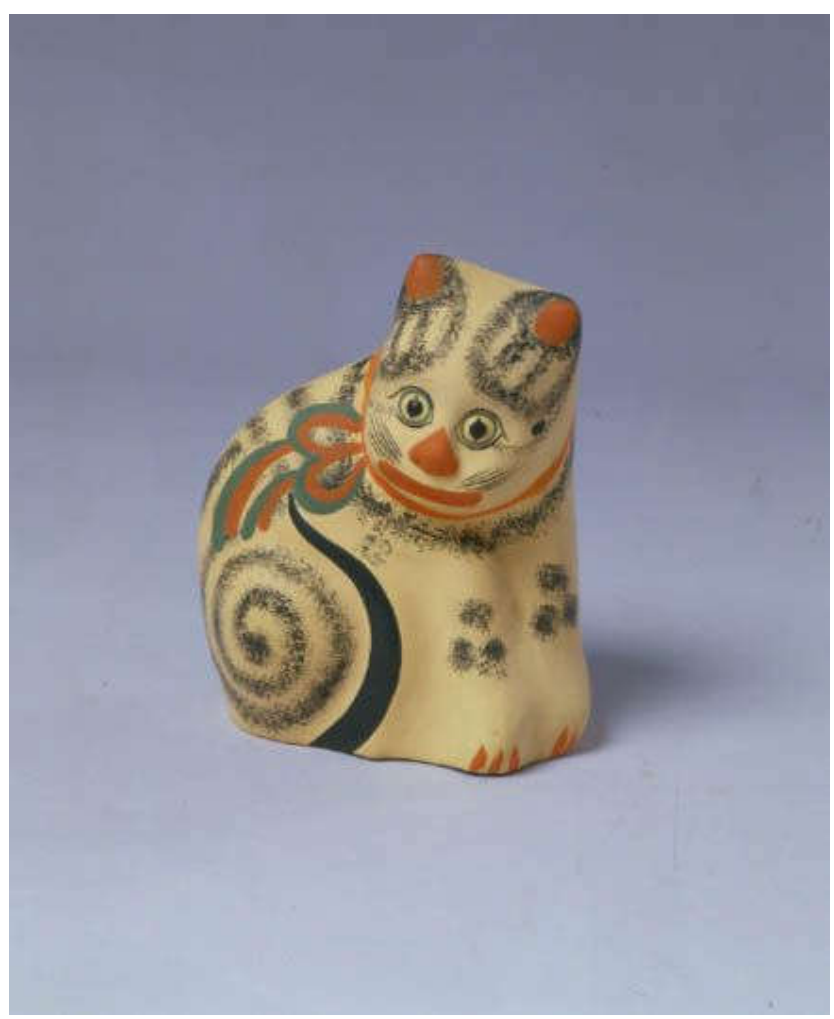

Cat of Huishan clay figurines 


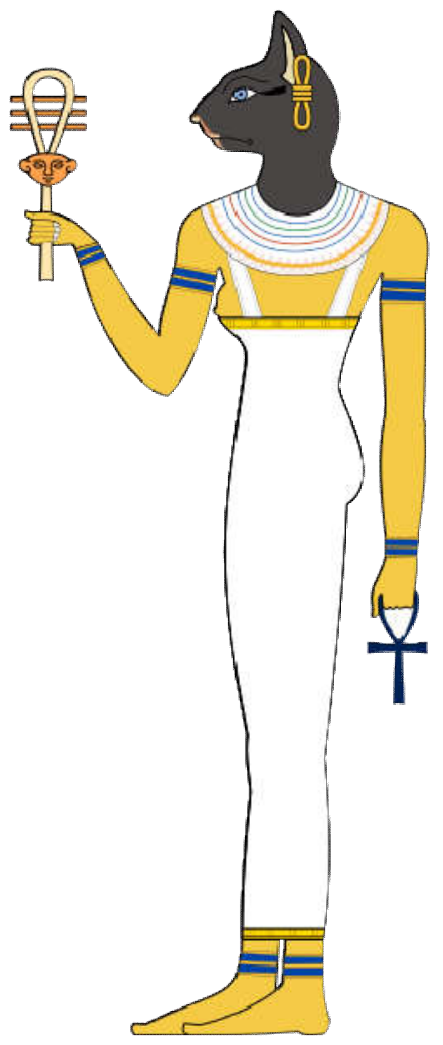

Bastet or Bast (Ancient Egyptian: b3stjt "She of the Ointment Jar") was a goddess of ancient Egyptian religion, worshiped as early as the Second Dynasty (2890 BCE). 


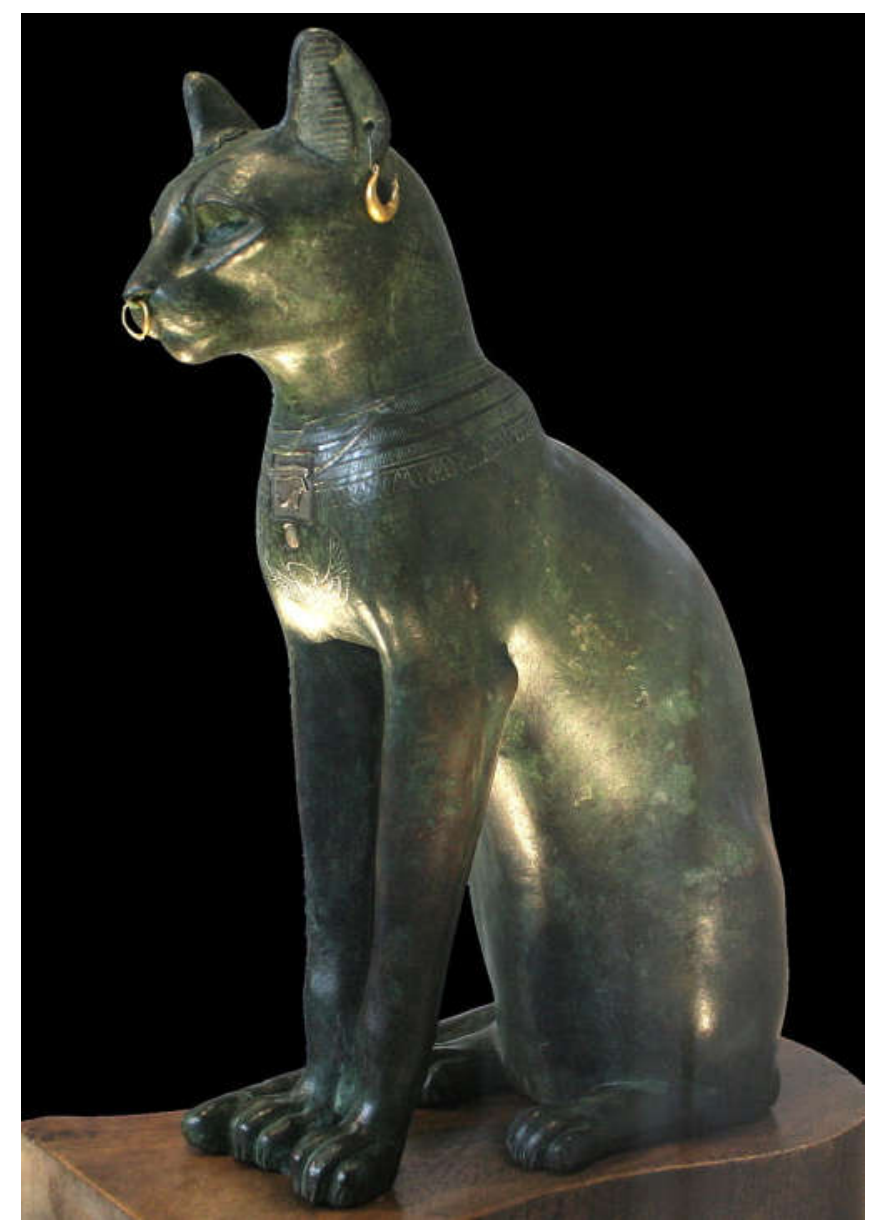

The Gayer-Anderson cat, believed to be a representation of Bastet

Now let us back to Egypt. The ushabti (also called shabti or shawabti, with a number of variant spellings) was a funerary figurine used in ancient Egyptian religion. Ushabtis were placed in tombs among the grave goods and were intended to act as servants or minions for the deceased, should they be called upon to do manual labor in the afterlife.

The practice of using ushabtis originated in the Old Kingdom of Egypt (c. 2600 to 2100 BCE), with the use of life-sized reserve heads made from limestone, which were buried with the mummy. Most ushabtis were of minor size, and many produced in multiples - they sometimes covered the floor around a sarcophagus. It was necessary for 
the owner's name to be inscribed on an ushabti, along with a phrase sending them to action, written in the hieratic script. (Taylor, Richard. "SHABTI (USHABTI, SHAWABTI)." Death and the Afterlife: a cultural encyclopedia. California: 2000.)

The term ushabti became prevalent after the 21st Dynasty and remained in use until the Ptolemaic Kingdom.

Ushabtis were mostly mummiform, but during the Dynasty XVIII reign of Thutmose IV, they began to be fashioned as servants with baskets, sacks, and other agricultural tools. Some ushabtis were very beautiful in form, and in colour, when of enamel. ( "Relics of Ancient Egypt". 1916. The Lotus Magazine. 7 (5): 213-214.) They were made of clay, wood or stone; (Brier, op. cit., p.186) early ones were sometimes made from wax also.

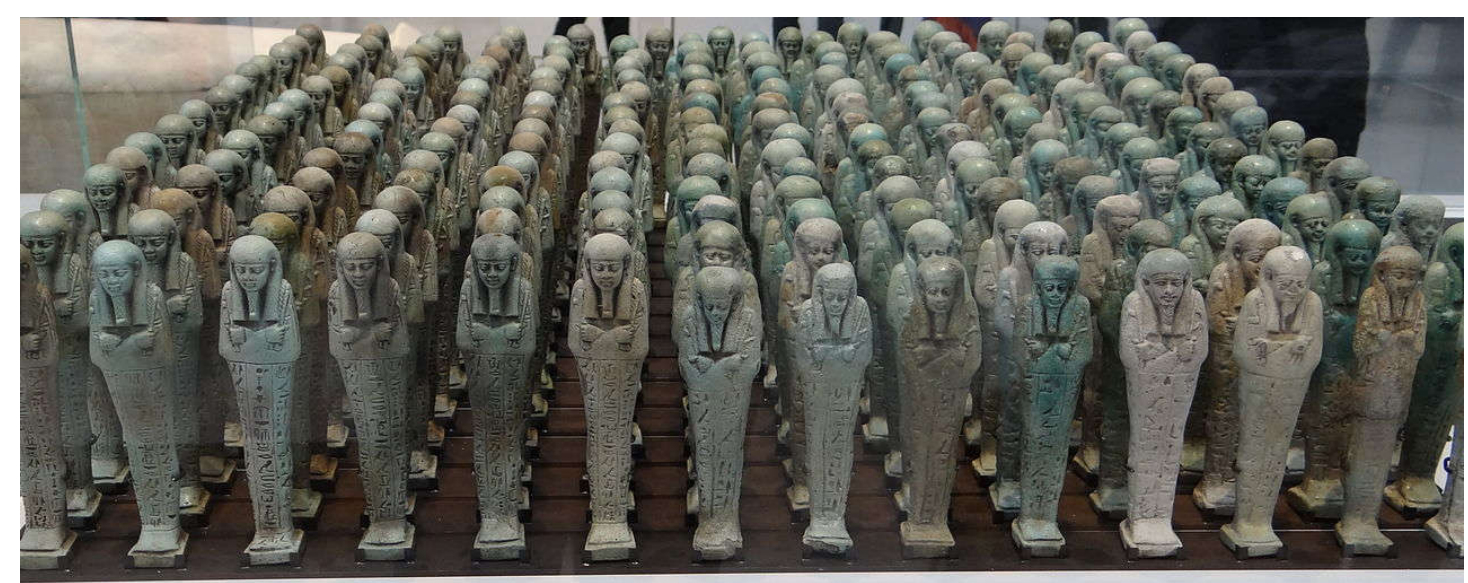

Memphis, $500 \mathrm{BC}$ - Troop of funerary servant figures ushabtis in the name of Neferibreheb, Louvre-Lens 


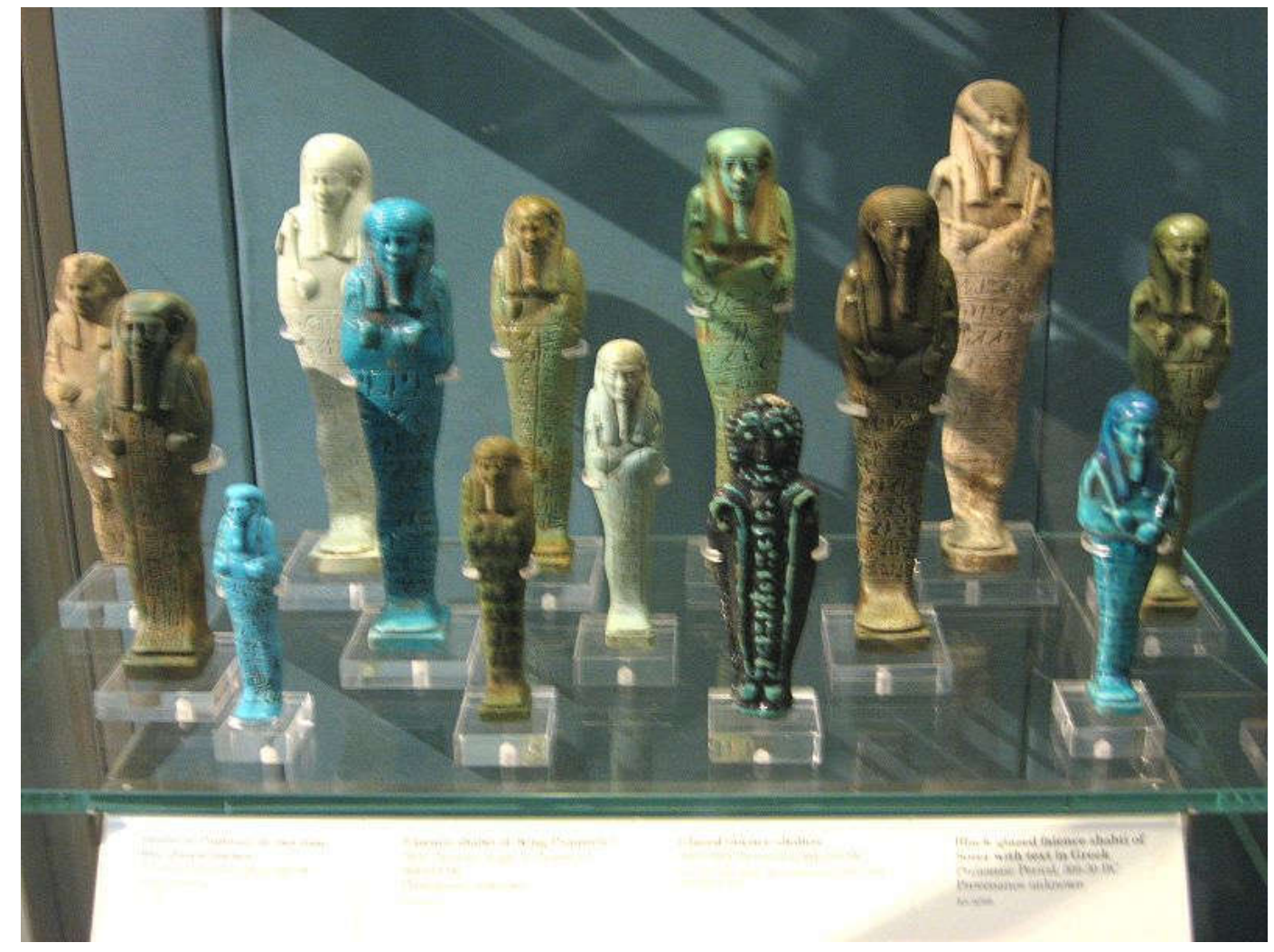

Ushabti in the British Museum in London

As it talked above, we can conclude that Huishan clay figurines（惠山 泥人） are ushabtis with Chinese characteristic, it indicates that Wuxi（无 锡）was the colony of ancient Egypt. Furthermore, Despite varied tales, many modern Chinese scholars favour the view that the word Wuxi derived from the "old Yue language" (百越语) or, supposedly, the old Kra-Dai languages. Wu means spot in "old Yue language". And what does Xi mean? As it talked above, Wuxi was once the colony of Egypt. In Egyptian hieroglyphs, the pronunciation of the hieroglyph

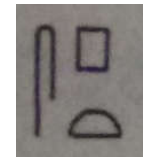
is spt or sit, and $\mathrm{Xi}$ in Wuxi of Wuxi dialect is read si, similar, right? The meaning of the hieroglyph

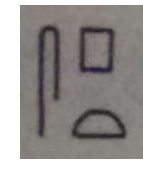

is binding. So Wuxi (无锡) means 
binding spot, Mount Xi（锡山） means a binding hill.

Now let us back to Egypt. The Narmer Macehead forms part of the Main Deposit found in 1899 at Hierakonpolis, and is now housed in the Ashmolean Museum,Oxford. Three bound captives seem to be given to Narmer, labels around them saying 120,000 captives in total(McDermott, B.(2004))with 400,000 cattle and 1,422,000 sheep and goats though this figure can in no way be credible.(Wilkinson, T, A, H. (2001) )

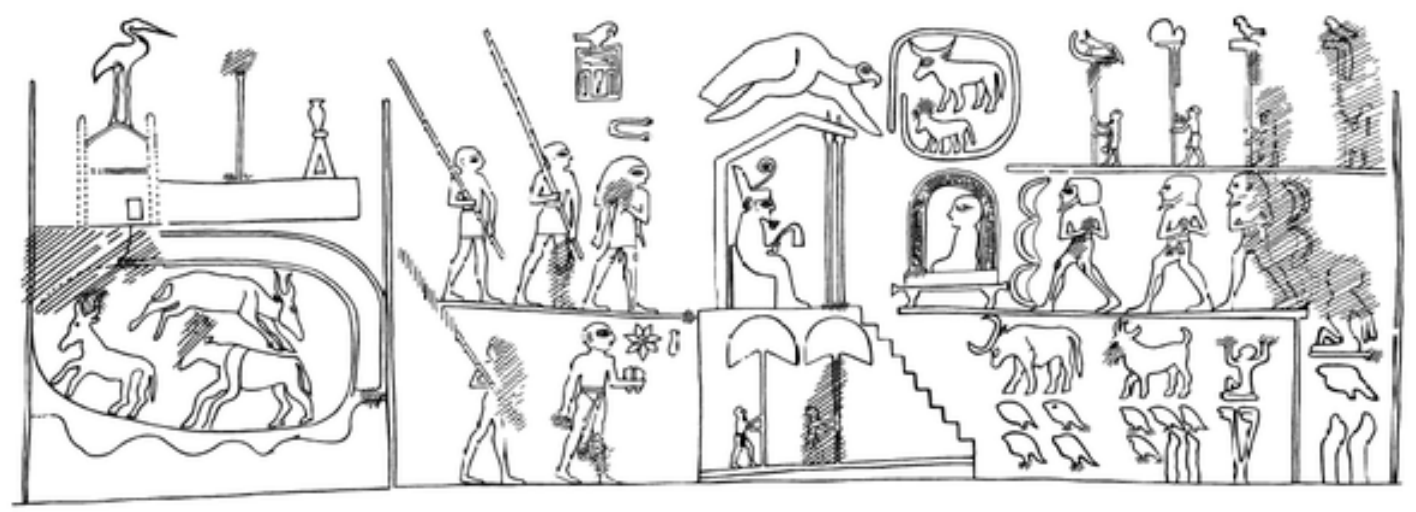

Narmer Macehead Drawing

Here, we find the trampling of the "Nine Bows", as the Egyptian referred to their enemies, as a vivid embodiment of the king's supremacy over foreigners (and sometimes even other Egyptians). The figure "nine" represented three times three, which was the "plurality of Pluralities", thus designating the entirety of all enemies. And later, during the New Kingdom, the Sphinx Stele of Amenhotep II provides a striking textual description of the Egyptian King smiting his enemies:

"He bound the heads of the Nine Bows... He has gathered them all into his fist, his mace has crashed upon their heads..." 


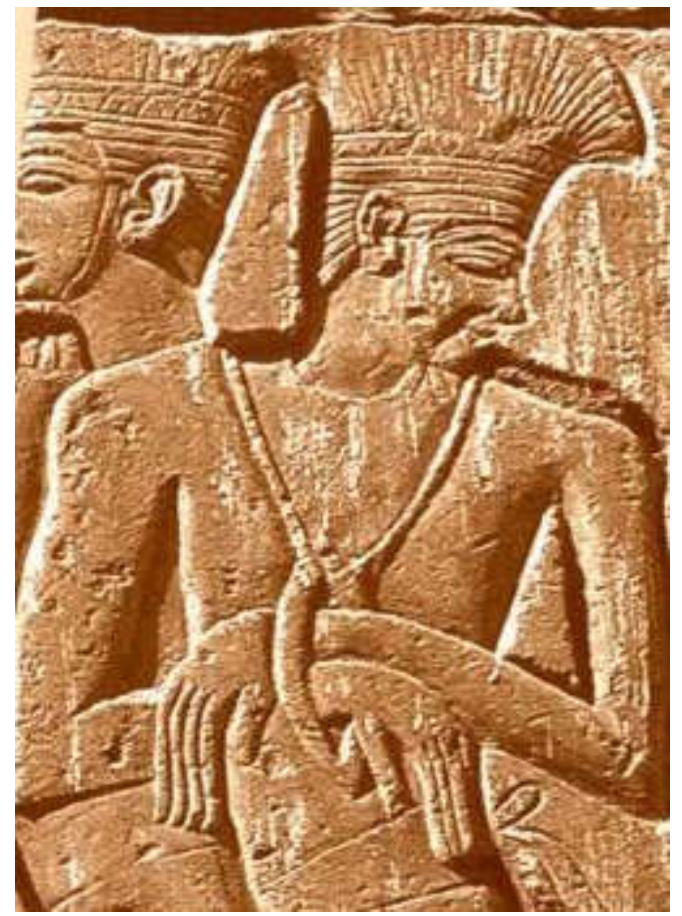

Bound captives in ancient Egypt

During the New Kingdom and Ptolemy period, a large number of temples were built. The scenes of the pharaoh grabbing the foreign captives' hair and beating them head-on and the foreign captives being bound and killed repeatedly appeared.

As it talked above, Mount Xi (锡山) means a binding hill, and pharaohs often bound captives since the first Dynasty. Besides, since Wuxi（无锡） was the colony of ancient Egypt, and the ruins of Mount Xi(锡山) resemble "Pyramid of Khufu" in Giza pyramid complex. So we can get a hypothesis that Mount Xi(锡山) is a man-made pyramid. Besides, the height of Mount $\mathrm{Xi}($ 锡山) is $66.8 \mathrm{~m}$, it is higher than the Pyramid of Djoser and lower than the Red Pyramid built by the founding of the Fourth Dynasty Pharaoh Sneferu. Mount Xi(锡山)is relatively high in most of the major pyramids in Egypt. Furthermore, Wuxi （无锡）is the 
cradle of Chinese Wu culture (吴文化)，I think this is owing to Huni. So from the above, we can speculate that Huni probably buried in Mount Xi , Wuxi (无锡锡山).

Another example can also be found to prove this. The Land of Punt (Egyptian: pwnt; alternate Egyptological readings Pwene(t)) was an ancient kingdom. A trading partner of Egypt, it was known for producing and exporting gold, aromatic resins, blackwood, ebony, ivory, and wild animals. The region is known from ancient Egyptian records of trade expeditions to it. (Shaw \& Nicholson, p.231.) It is possible that it corresponds to Opone as later known by the ancient Greeks, while some biblical scholars have identified it with the biblical land of Put.

At times Punt is referred to as Ta netjer (t3 $n \underline{t} r)$, the "Land of the God". ( Breasted, John Henry (1906-1907), Ancient Records of Egypt) The exact location of Punt is still debated by historians. Most scholars today believe Punt was situated to the southeast of Egypt, most likely in the coastal region of modern Djibouti, Somalia, northeast Ethiopia, Eritrea, and the Red Sea littoral of Sudan. ( Simson Najovits, Egypt, trunk of the tree, Volume 2, (Algora Publishing: 2004), p.258.) It is also possible that the territory covered both the Horn of Africa and Southern Arabia. (Dimitri Meeks - Chapter 4 - "Locating Punt" from the book Mysterious Lands", by David B. O'Connor and Stephen Quirke.)

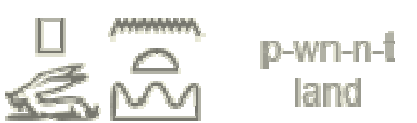

Egyptian spelling "pwenet", the feminine "t" ending was not pronounced during the 
New Kingdom. The last sign is the determinative for country, land

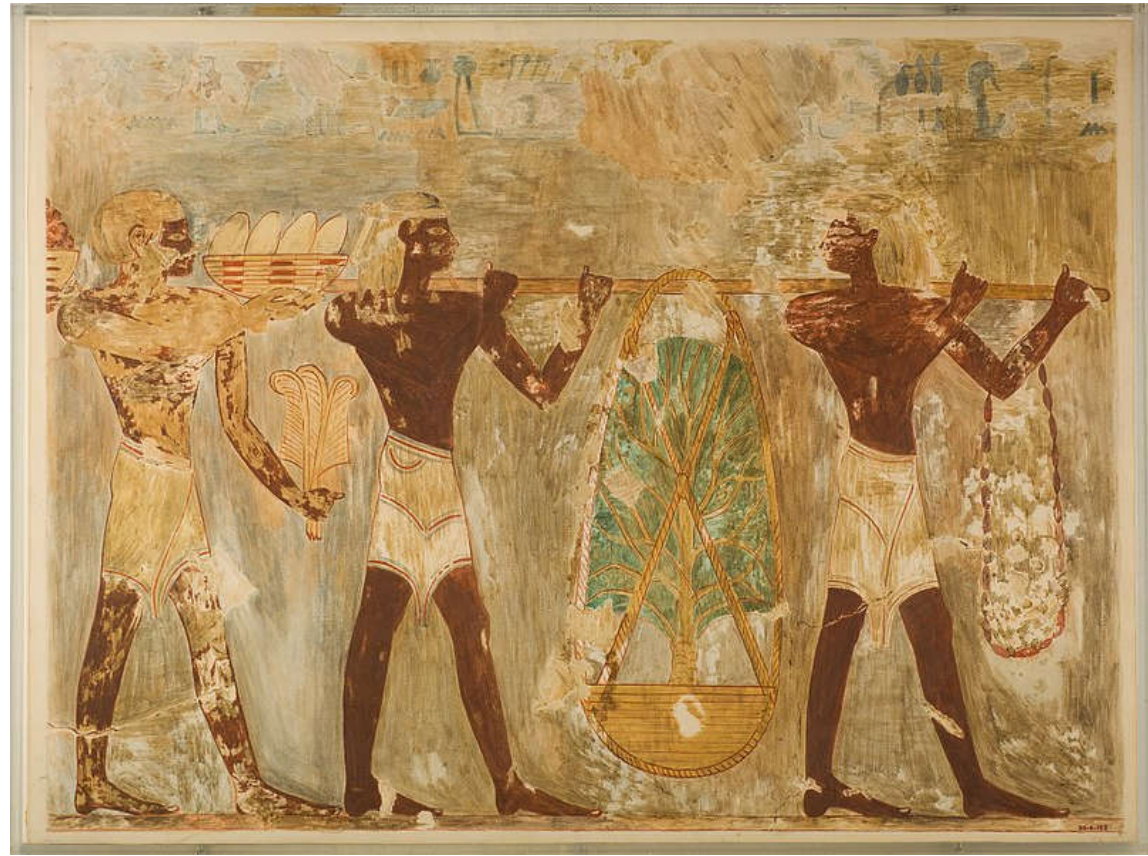

Men from Punt carrying Gifts, Tomb of Rekhmire

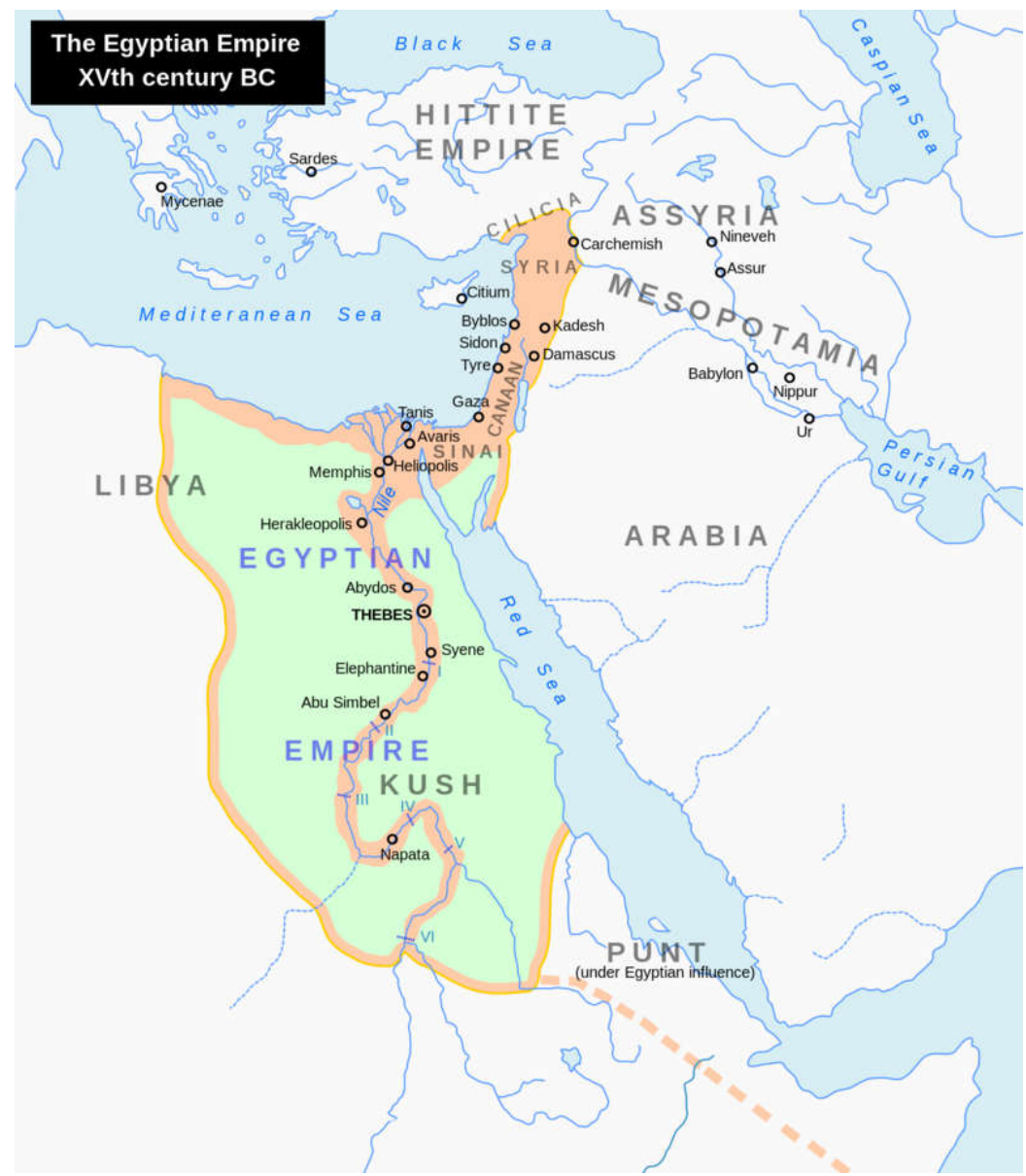

Location of the Land of Punt for most scholars. 
Now let us connect Mount Xi(锡山), Chanshan Hill(产山) and Zhangshan Hill (嶂山)with a straight line(I think Mount Xi(锡山), Chanshan Hill (产山) and Zhangshan Hill（嶂山), the arrangement of the three resemble the pyramids in northern group of Saqqara ) and extend it, as the image below:

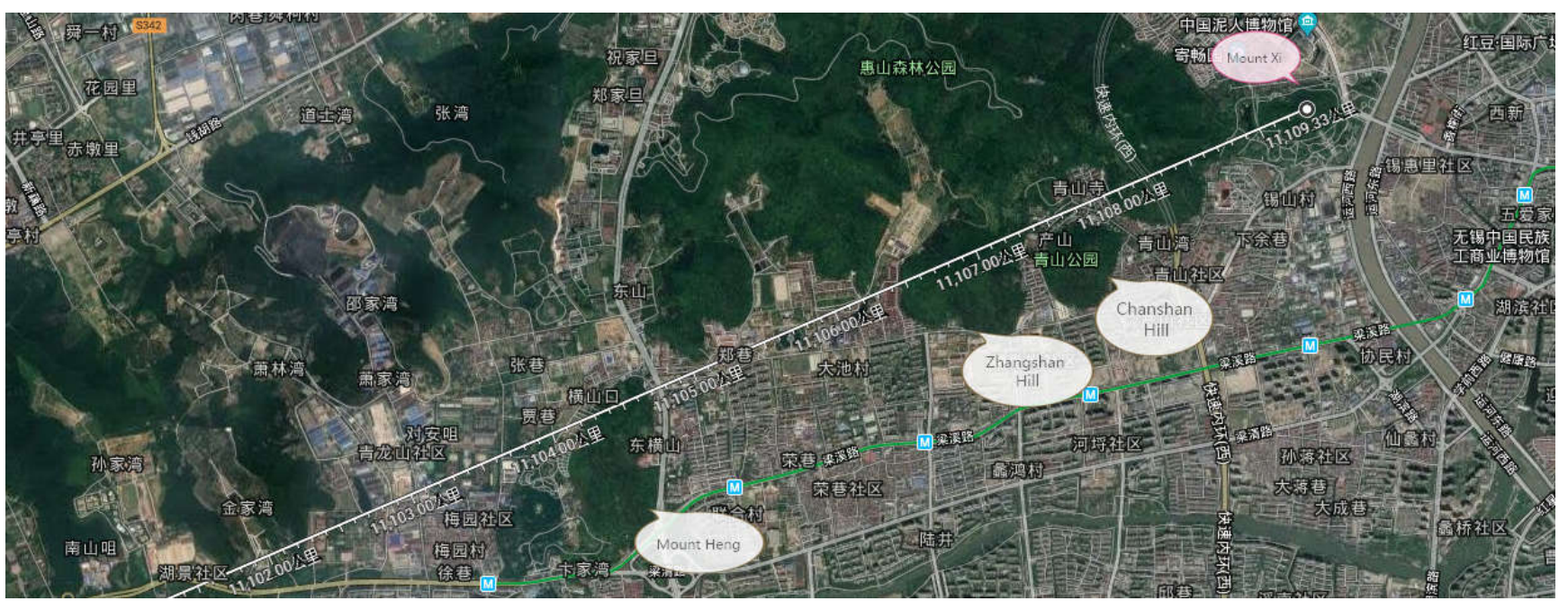

Then we will first meet a pyramid shaped mountain-Mount Heng (横 山), as the picture below:

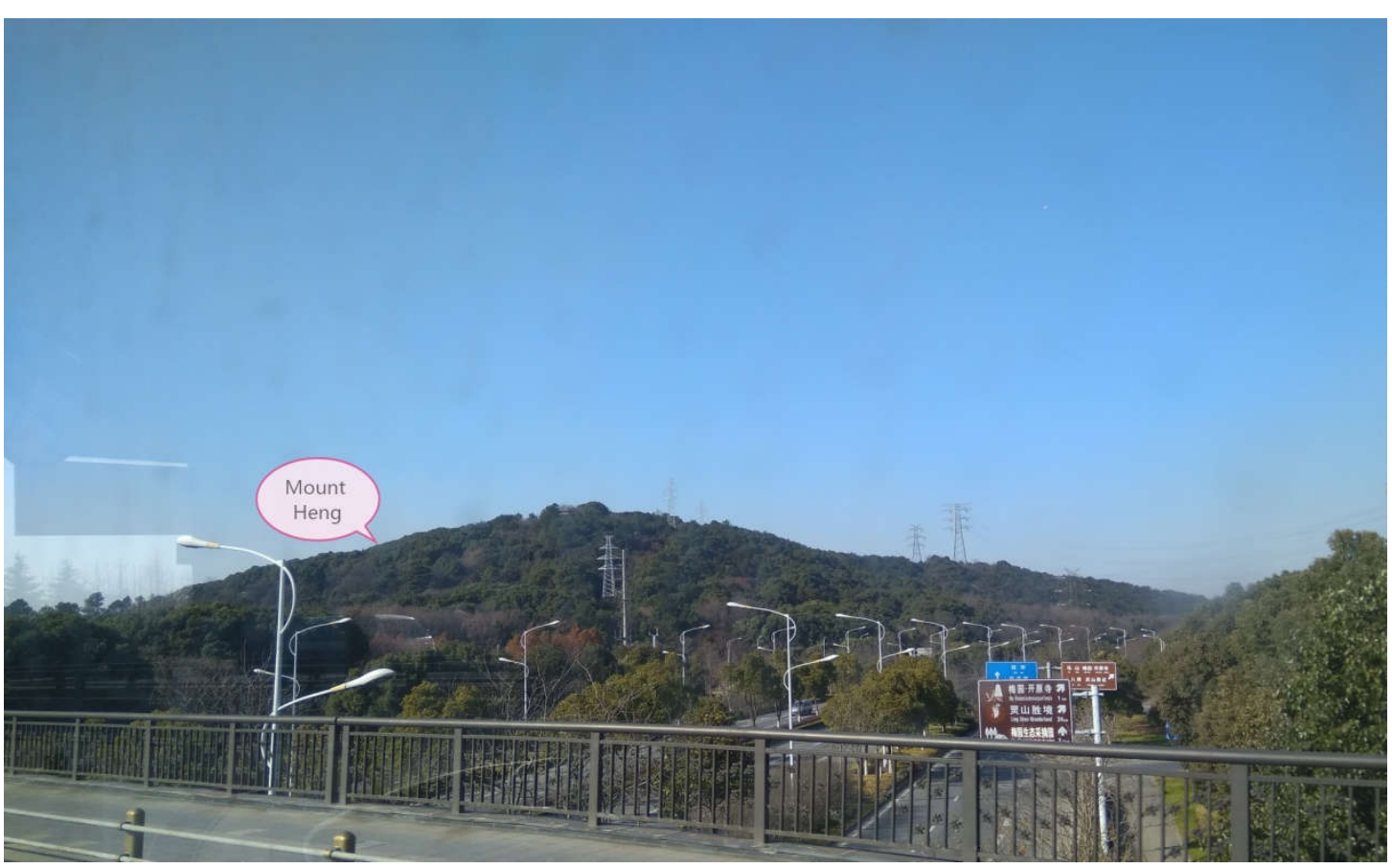

Mount Heng (横山) 


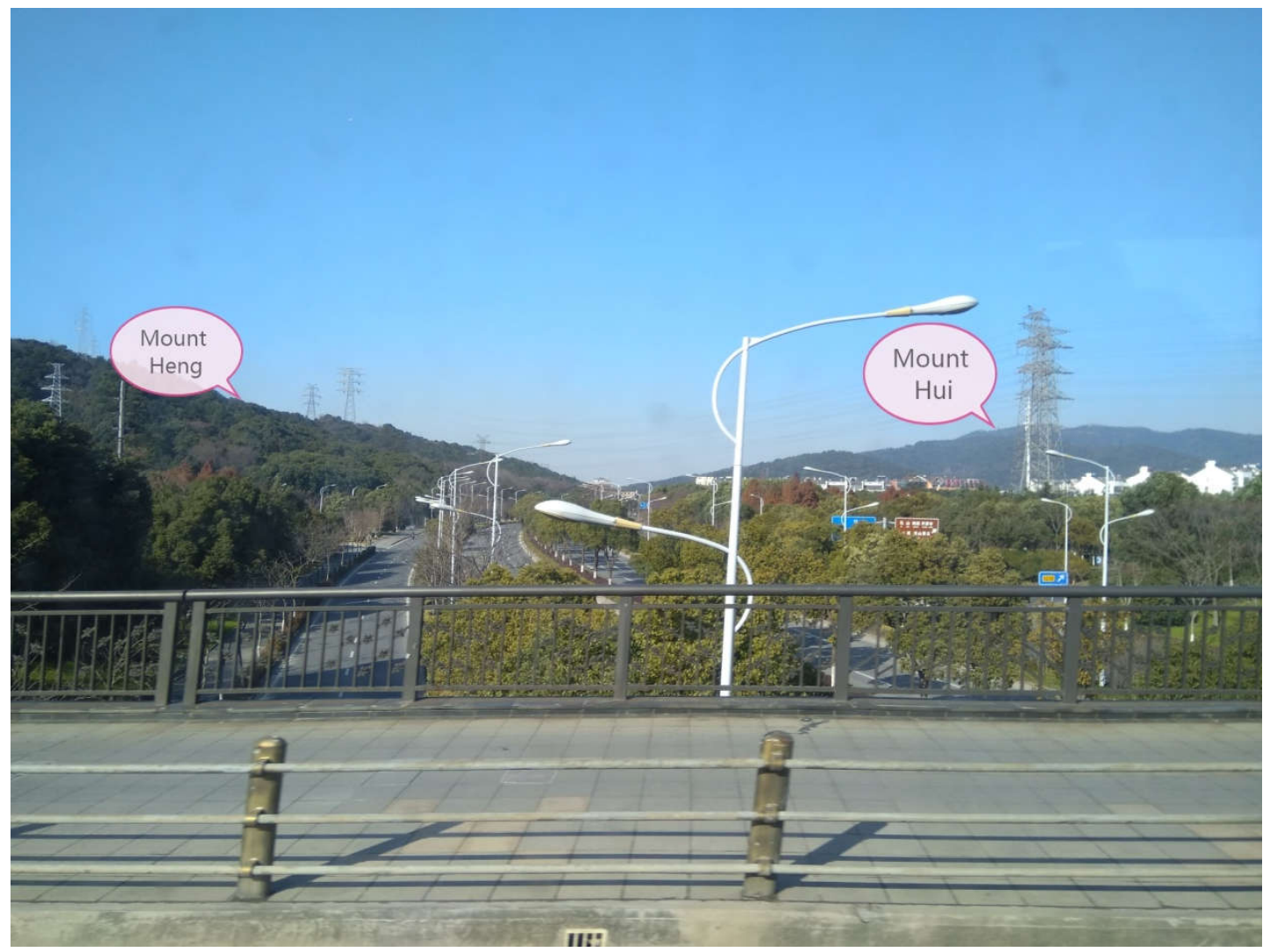

Mount Heng (横山) and Mount Hui (惠山), the left is Mount Heng (横山) and the right is Mount Hui (惠山).

Next we will meet Helv City（䛜闾城）and Longshan Stone Tombs（龙 山石室土墩墓) :

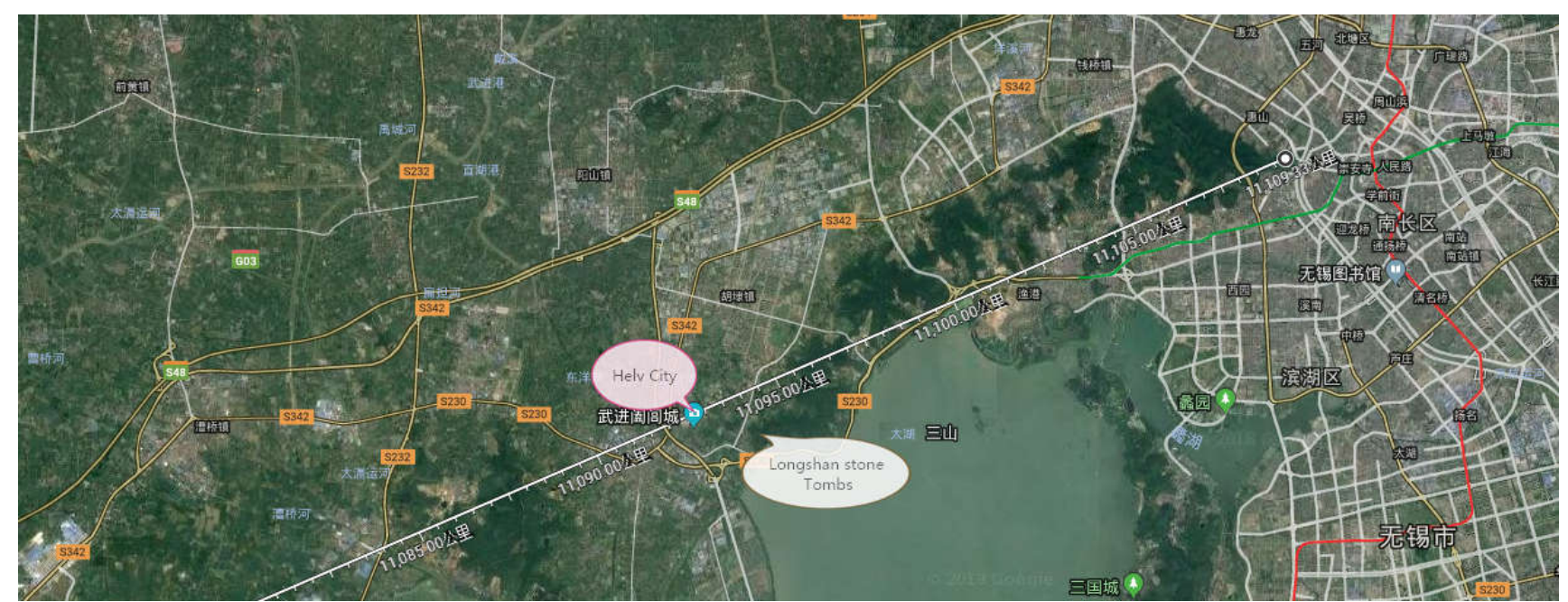

Helv City (馗闾城) and Longshan Stone Tombs (龙山石室土墩墓)

And the enlarged image of Helv City (槛闾城) and Longshan Stone

Tombs (龙山石室土墩墓) is the following: 


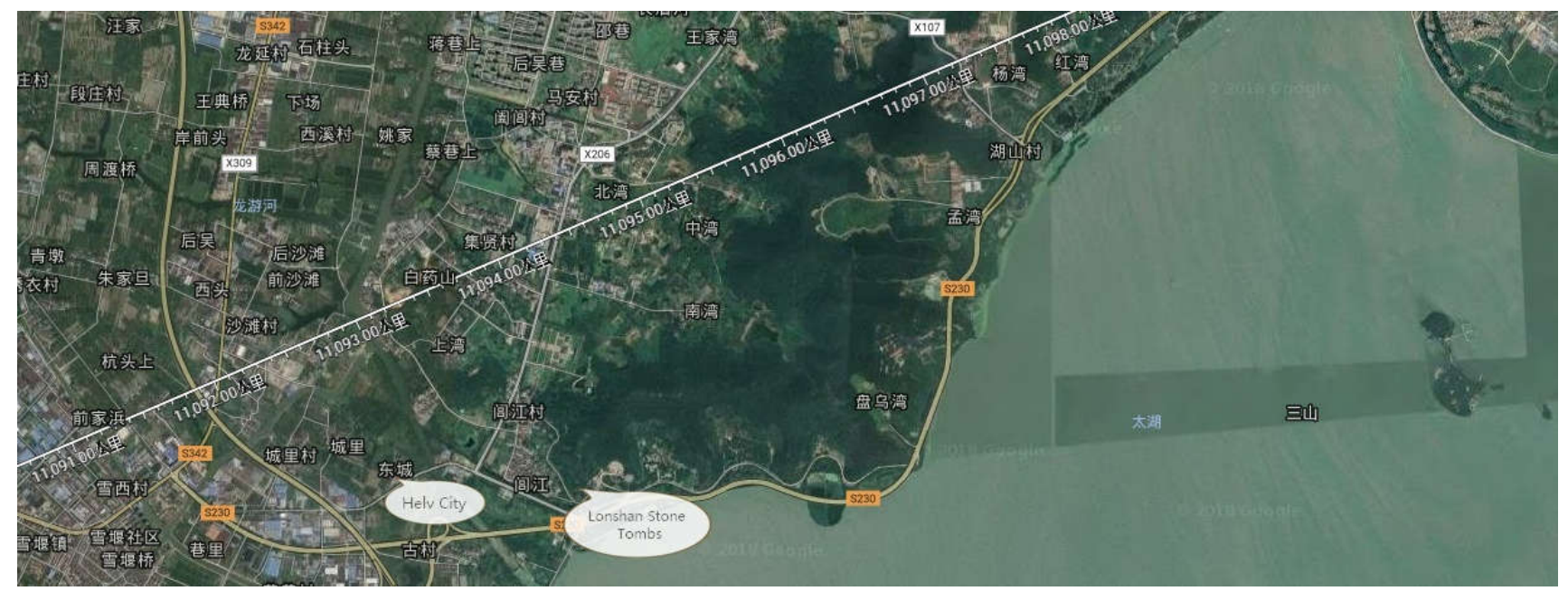

The enlarged image of Helv City (槛问城) and Longshan Stone Tombs (龙山石室土墩 墓)

Finally, we will meet the Land of Punt, about $11109 \mathrm{~km}$ away from Mount Xi，Wuxi (无锡锡山)，as the picture below:

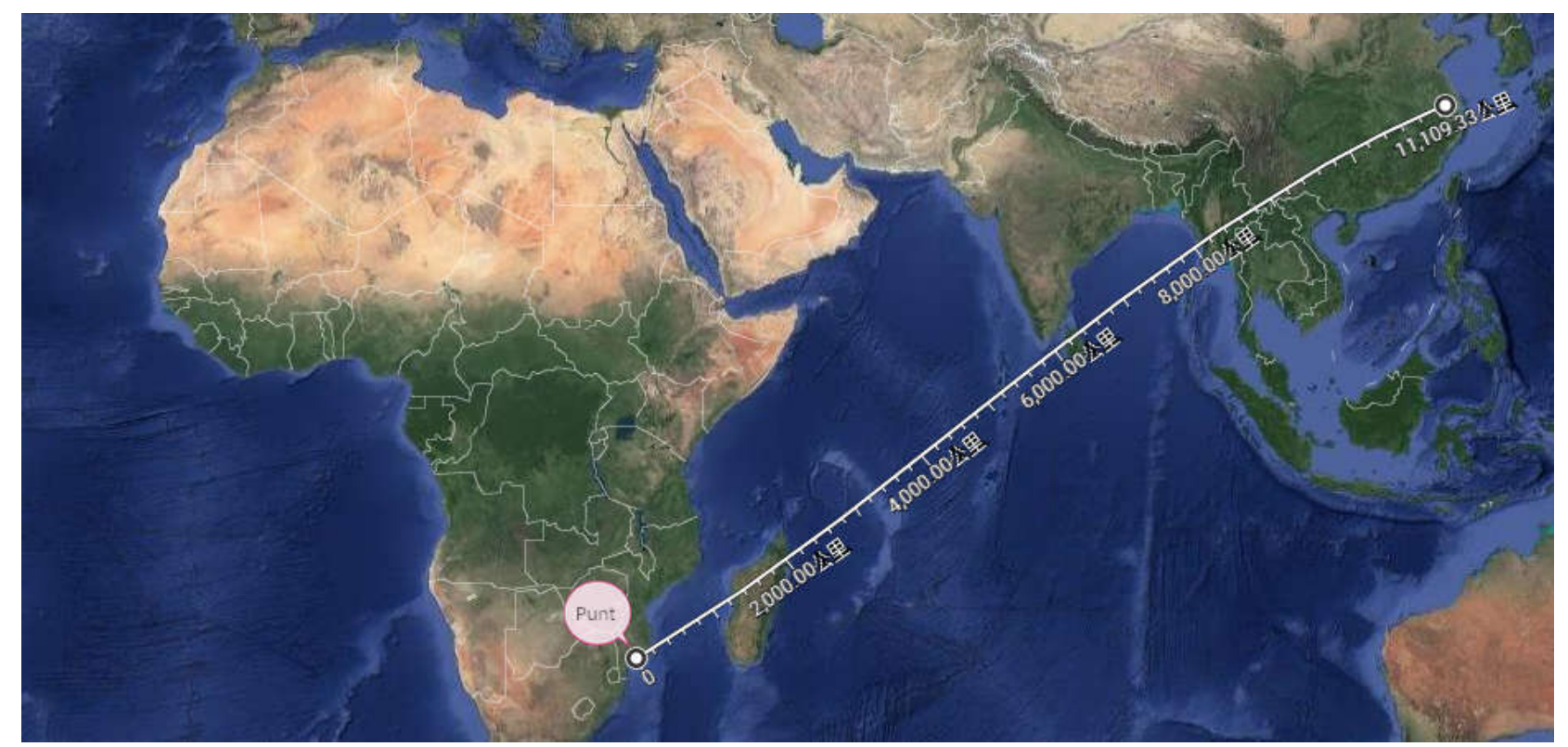

Punt

So in summary, we can get a conclusion that Huni probably buried in

Mount Xi，Wuxi (无锡锡山).

References:

1. https://en.wikipedia.org/wiki/Huni

2. https://en.wikipedia.org/wiki/Meidum 
3. http://blog.sina.com.cn/s/blog_6a4e1c6f0102vjqy.html（兵策儒剑 一确证古埃及第三王朝法老胡尼就是吴回）

4. https://en.wikipedia.org/wiki/List_of_Egyptian_hieroglyphs

5. https://baike.baidu.com/item/\%E5\%A4\%A9\%E5\%90\%B4/1094623 $3 ? f r=a l a d d i n （$ 百度百科一天吴）

6. https://en.wikipedia.org/wiki/Heh_(god)

7. https://en.wikipedia.org/wiki/Egyptian_pyramids\#cite_note-reuter s1-3

8. https://escholarship.org/uc/item/9wz0c837

9. http://www.globalcitymap.com/egypt/pyramid-map.php

10. https://en.wikipedia.org/wiki/Layer_Pyramid

11. https://en.wikipedia.org/wiki/Saqqara

12.http://www.encyclopedie.bseditions.fr/article.php?pArticleld=59\& pChapitreld=21446\&pArticleLib=Pr\%E9ambule+\%5BEgypte $+\% 3 A+L$ $a+n \% E 9$ cropole+de+Saqqara\%5D

13.https://www.worldhistory.biz/ancient-history/65603-6-2-the-3rd-d ynasty-djoser-s-step-pyramid-at-saqqara.html

14. https://en.wikipedia.org/wiki/Bent_Pyramid

15. https://en.wikipedia.org/wiki/Red_Pyramid

16. http://www.mafengwo.cn/photo/poi/6300627_33687509.html

17.https://www.researchgate.net/publication/277571532_Dahshur_E xcavation_Report_2002 
18. https://en.wikipedia.org/wiki/Hyperdiffusionism_in_archaeology

19. https://en.wikipedia.org/wiki/Haplogroup_Q-M242

20. http://blog.sina.com.cn/s/blog_6a4e1c6f01010qvr.html（兵策儒 剑 $-\mathrm{Y}-\mathrm{Q}$ 系全球迁徙路线推测图)

21. http://blog.sina.com.cn/s/blog_6a4e1c6f0101c9zz.html（兵策儒 剑一古埃及人 2 个常染标记基因在全世界的分布）

22.https://en.wikipedia.org/wiki/Y-DNA_haplogroups_in_populations _of_North_Africa

23.https://www.researchgate.net/publication/6180520_Y_chromoso mes_of_Prehistoric_People_along_the_Yangtze_River

24. http://blog.sina.com.cn/s/blog_6a4e1c6f0102y0dj.html

25. https://en.wikipedia.org/wiki/Taibo

26. http://blog.sina.com.cn/s/blog_3fe8ebaa01017aef.html （EpochOfYao一无锡名人墓 2一泰伯墓）

27. https://en.wikipedia.org/wiki/Yue_(state)

28. https://en.wikipedia.org/wiki/Horus

29. http://blog.sina.com.cn/s/blog_6a4e1c6f0102xab0.html（兵策儒 剑一玉璋的古埃及起源）

30. http://chineseetymology.org

31. https://sns.91ddcc.com/t/17914 (惠山泥人_中国传统文化社区 _才府)

32. https://en.wikipedia.org/wiki/Xihui_Park 
33. http://blog.sina.com.cn/s/blog_5d2f3e160100h2pk.html（马崧 良子一吴论七八一良渚聚落特征）

34. http://www.sohu.com/a/232876698_467440 （纪念郑张尚芳先 生 | “今日何日兮, 得与王子同舟” )

35. https://www.sohu.com/a/5925574_119016（无锡锡惠公园, 你 所没见过的夜景）

36. https://cn.hujiang.com/new/p575014/

37. http://cityguide.china.org.cn/shop/shop.php?shopid=3922

38. https://en.wikipedia.org/wiki/Huishan_clay_figurine

39. https://en.wikipedia.org/wiki/Bastet

40. https://en.wikipedia.org/wiki/Ushabti

41. https://en.wikipedia.org/wiki/Wuxi

42. How to Read Egyptian Hieroglyphs, by Mark Collier, Bill Manley, 2004 Version.

43. http://ancientegypt.wikia.com/wiki/Narmer_Macehead

44. http://www.touregypt.net/featurestories/enemies.htm

45. http://www.sohu.com/a/127732576_523159（王欢｜古代埃及 文献中的赫梯国王形象）

46. https://en.wikipedia.org/wiki/Land_of_Punt 